Universidade de São Paulo

Faculdade de Filosofia, Letras e Ciências Humanas.

Departamento de Teoria Literária e Literatura Comparada

FABRÍCIO CARLOS CLEMENTE

\title{
ESTILHAÇOS DE VISÕES: POESIA E POÉTICA EM ROBERTO PIVA E CLAUDIO WILLER
}




\section{FABRÍCIO CARLOS CLEMENTE}

Estilhaços de visões: poesia e poética em Roberto Piva e Claudio Willer

Dissertação apresentada ao programa de PósGraduação do Departamento de Teoria Literária e Literatura Comparada da Faculdade de Filosofia, Letras e Ciências Humanas da Universidade de São Paulo para obtenção do título de Mestre em Teoria Literária e Literatura Comparada.

Área de concentração: Teoria Literária e Literatura Comparada.

Orientação: Prof. Dra. Viviana Bosi. 


\section{RESUMO}

Esta dissertação procura interpretar a obra dos poetas contemporâneos brasileiros Roberto Piva e Claudio Willer tendo em vista a tradição que invocam em suas produções, a qual aponta para as matrizes teóricas do romantismo e se desenvolve na modernidade sendo radicalizada pelas vanguardas históricas, pelo surrealismo e pela geração beat. O texto se foca na relação entre poesia e práxis vital no intuito de ressaltar como os poetas aqui estudados elaboram uma poética ao mesmo tempo em que negam tal intento.

Palavras-chave: Roberto Piva, Claudio Willer, Poesia brasileira, Romantismo, Vanguardas, Surrealismo, Geração Beat. 


\begin{abstract}
This dissertation seeks to interpret the work of the contemporary Brazilian poets Roberto Piva and Claudio Willer in view of the tradition that they invoke in their productions, which points to the theoretical frameworks of romanticism and it is developed throughout modernity being radicalized by historical avant-gardes, surrealism and beat generation. The text focuses on the relation between poetry and vital praxis to highlight how the poets studied here develop a poetic while at the same time deny such intent.
\end{abstract}

Keywords: Roberto Piva, Claudio Willer, Brazilian Poetry, Romanticism, avant-gardes, Surrealism, Beat Generation. 


\section{AGRADECIMENTOS}

À cidade de São Paulo porque me deu a vibração exata para compreender suas convulsões de Princesa Hostil entre carrosséis do incêndio. Ao poeta Claudio Willer porque mostrou uma rota de fuga enquanto o sol sufocava sob as botas dos coronéis de Urubu-Dormitório e também por ter me arranjado informações e material raro e inédito. Ao poeta Roberto Piva que arrombou os portões do sexo da Princesa e lançou em meus olhos uma Biblioteca fugitiva. À minha orientadora Viviana Bosi porque me ofereceu as armas necessárias para iniciar a caça à Babel, criando (com paciência búdica e olhos de águia) regatos de luz no labirinto. À Mel que dissertou comigo sobre a vida animal dos deuses. À Goiandira Ortiz que me ensinou a sentir na pele-sombra da imagem poética a incandescência de mármore do verbo. À Joana D’Arc Ribeiro, que numa tarde de província, jogou-me à mão um exemplar de Artaud falando por setenta e duas horas sem parar sobre Mimese e o Infinito deixando-me vidrado frente às frestas do cosmos. Ao Professor Murilo Marcondes Moura porque me emprestou as raras primeiras edições de Anotações pra um apocalipse, Piazzas e Paranoia, com generosidade anárquica a la Murilo Mendes. À Camila Rosa que modulou o abismo na língua de Whitman. A Eclair Antonio Almeida Filho que me cedeu à maneira surrealista suas traduções inéditas de Robert Desnos. A Luiz de Mattos Alves, Maria Netta e Maria Ângela do DTLLC, exemplos de profissionalismo e gentileza. Ao amigo Márcio Zuffa que me trouxe ruivas teorias da Irlanda, concebendo apocalipses e partituras. À minha mãe cujo amor me ensinou a buscar a Margem. A todos da Nau conhecida pelos exilados como vida miúda e ao poeta Wilton Cardoso, Capitão Anarquista do Navio Pirata. Aos integrantes da minha banca de qualificação Prof. Fábio de Souza Andrade e Profa. Maria Augusta Fonseca que trouxeram andaimes mais que instigantes a este trabalho. Ao amigo Alessandro Lima que sabe o que é beat e à sua mãe Rita que sabe quem são os beats. 
À Moema, meu campo de morangos vivos. 


\section{SUMÁRIO}

INTRODUÇÃO____ 8

I - SALTIMBANCOS DE UMA NOVA ORDEM DAS COISAS

I.I - OS QUE VIRAM A CARCAÇA 38

I.II - A PERFEITA MÚSICA ESTÁ NO AÇO 44

I.III - ESTREPOLIAS DA VANGUARDA 52

II- O ANTIGO CLAMOR DOS PIRATAS TRUCIDADOS 58

III- DE BRUXOS E POETAS \& NOTAS CONCLUSIVAS 92

ANEXO (Manifestos) 109

REFERÊNCIAS BIBLIOGRÁFICAS 113 


\section{INTRODUÇÃO}

Há espaço para todos. De nenhum a senda está marcada

Hölderlin

O marco de referência da produção dos poetas contemporâneos brasileiros Roberto Piva e Claudio Willer encontra-se na leva de autores apresentados ao público da São Paulo dos anos sessenta pelo importante trabalho do editor Massao Ohno. A Antologia dos Novíssimos (1961) juntamente com a coleção homônima, mais os projetos de títulos inequívocos tais como "coleção Maldoror" tiraram do ineditismo muitos dos jovens escritores que então surgiam no cenário paulistano.

Em depoimento publicado na antologia Artes e Ofícios da Poesia (1991) o poeta Antonio Fernando De Franceschi afirma que as diferentes vozes e concepções artísticas presentes entre os Novíssimos “(...) não se organizaram como movimento nem defendiam teses relacionadas a um "projeto geral de criação"” (p. 66). Destacando esse elemento basilar, o poeta e crítico Carlos Felipe Moisés diz que "jamais vingou” entre esses artistas "a hipótese de cerrar fileiras em torno de qualquer doutrina ou plataforma

\footnotetext{
${ }^{1}$ No final de outubro de 1964 são lançados, na mesma ocasião, em um bar denominado Barroquinho (que se localizava no subsolo da Galeria Metrópole no centro de São Paulo) os volumes n ${ }^{\circ} 1$ e ${ }^{\circ} 2$ da Coleção Maldoror, respectivamente com o livro de estreia de Willer, Anotações para um apocalipse, e Piazzas, segunda obra de Roberto Piva, já então aclamado entre coevos pelo hoje célebre Paranoia. Vale observar que, alguns anos depois, em 1970, Claudio Willer traz a lume sua tradução dos Cantos de Maldoror de Lautréamont, com ilustrações da artista plástica e companheira de geração Maninha Cavalcanti. É interessante notar ainda (tendo em vista a sintonia do espírito do tempo que isto enseja) como estes Anotações para um apocalipse e Piazzas se parecem, quanto ao aspecto gráfico, com algumas edições da City Lights Books, a editora do poeta beat Lawrence Ferlinghetti, como as primeiras de Howl, de 1956, e Kaddish and other poems de Allen Ginsberg, de 1961. Tanto os beats, como Lautréamont são seminais para as obras de Piva e Willer, como veremos.
} 
(...)".2 Desse modo, é possível encontrar obras poéticas tão distintas como as de Sérgio Lima, Rubens Rodrigues Torres Filho, Eunice Arruda, de Bruno Tolentino, dos próprios De Franceschi e Carlos Felipe Moisés, ${ }^{3}$ de Neide Archanjo e tantos outros, coexistindo em volta do mesmo trabalho editorial e no mesmo contexto criativo.

Ao contemplar esta vasta gama de produção literária é impossível que não nos questionemos: além dos traços de afetividade e convivência, quais seriam os pontos de contato entre esses autores? São esclarecedoras nesse sentido as palavras da pesquisadora da "Geração sessenta" brasileira, Nelly Novaes Coelho. ${ }^{4}$ Como nos mostra a estudiosa, os traços que caracterizam os poetas surgidos nessa época confundem-se com a problemática existencial decorrente da guerra fria e do período pós-getuliano, com o advento do governo de Juscelino Kubitscheck e a construção de Brasília. Em tais circunstâncias, segundo a autora, "Formas de destruição e de criação mediam forças", sendo então, para a poesia, “(...) um tempo de interrogação e buscas a partir de uma certeza: ao poeta cabia renomear um mundo em caos e abrir caminho para uma nova ordem, que havia de vir" (COELHO, 2002). Quais seriam essas forças destrutivas e criativas? Em que, necessariamente consistiriam os questionamentos então enfrentados? Quais as implicações estético-ideológicas de semelhante situação?

Ao referir-se ao contexto brasileiro como um todo, listando nomes como Carlos Nejar, Armindo Trevisan, mencionando também alguns integrantes dos Novíssimos de São Paulo como os próprios Piva e Willer, entre outros, Coelho salienta que se trata de "Vozes e formas poéticas bem diferentes entre si, fortemente personalizadas, mas que,

\footnotetext{
${ }^{2}$ Em entrevista ao poeta Floriano Martins, disponível em: http://www.revista.agulha.nom.br/cfm4.html;

${ }^{3}$ De Franceschi não publica na época em questão, trazendo a lume seu primeiro livro, Tarde Revelada, somente na década de oitenta. No entanto, o caráter seminal da experiência com os novíssimos é inegável para sua formação.

${ }^{4}$ As ideias de Nelly Novaes Coelho aqui apresentadas, retiramos do Dicionário crítico das escritoras brasileiras, no verbete sobre a poeta Eunice Arruda.
} 
com o tempo, foram revelando raízes comuns e universais que hoje são vistas como marcas geracionais". Ao apontar esses sinais de aproximação, deixa evidente o caráter existencial, a profundidade intimista desta aventura humana em cujo centro se encontra a palavra poética e a necessidade de posicionamento frente ao mundo. A natureza demiúrgica dessa vivência se desnudaria nos seguintes elementos:

(...) crença quase absoluta no poeta (e na poesia) como a grande força de resistência contra a destruição da vida: descoberta da palavra como criadora do real (é ela que, nomeando o ser e as coisas, os fazem existentes): redescoberta da condição humana, como a grande força do universo (apesar de aparentemente efêmero e frágil, o Homem é indestrutível: é dele que depende a continuidade da vida em ciclos de evolução que se sucedem), e a consciência do eu como parte do nós, como elos que somos da grande corrente da História e, consequentemente, a consciência de que toda renovação cíclica se faz por uma volta às origens. (COELHO, 2002).

Parece dar-se em consonância com esse espírito a verve altissonante de Roberto

Piva e sua ideia da poesia declarada no "Postfácio" de seu segundo livro, Piazzas, de

1964. Também aí se colocam posicionamentos ético-estéticos à medida que se impõe reflexões em torno do ofício do verso como problemática indissociável do iminente desejo de liberdade e desvelamento do real. Instrumento da Visão. O poeta é sacerdote, seta incandescente a apontar para uma transmutação de valores. A arte poética, seus parâmetros e pressupostos, confundem-se com o destino humano em si mesmo:

Em todos os meus escritos procurei de uma forma blasfematória (Paranoia) ou numa contemplação além do bem \& do mal (Piazzas) a la Nietzsche explicitar minha revolta \& ajudar muitos a superar esta Tristeza Bíblica de todos nós, absortos num Paraíso Desumanizado, reprimido aqui \& agora. Já em minhas conversas com Willer \& leituras de Freud, Desnos, Ferenczi, Monnerot, eu consolidava mais e mais minha ideia da Poesia como instrumento de Libertação Psicológica \& Total, como a mais fascinante Orgia ao alcance do Homem.

("Postfácio", Piazzas, 1964) 
É também nessa perspectiva que Claudio Willer, nas primeiras linhas do ensaio “As fronteiras e dimensões do grito", publicado juntamente com a coletânea de poemas Anotações para um apocalipse, também de 1964, refere-se a um trecho excluído do livro $O$ Processo ${ }^{5}$ de Franz Kafka no qual, de modo trágico, o personagem K espantase, absurdamente, ao constatar serem o sono e o sonho estados em essência diferentes da vigília. Isso implicaria, segundo o personagem, que para enfrentar o instante após o transporte do mundo onírico ao real (no momento mesmo em que se acorda) seria necessário ter uma "presença de espírito infinita" e "um sentido espantoso de resposta" (WILLER, 1964, p.33) para situar tudo o que estava diante de si antes de se ter embarcado nesta perigosa e estranha viagem. Dessa forma, o momento do despertar seria o mais crucial, crítico e dramático do dia, pois exigiria ao indivíduo que abre os olhos diante do universo que o reconstruísse, o reintegrasse. O situar-se frente ao mundo e à História seria assim, para Willer, análogo ao despertar kafkiano, sendo o testemunho de semelhante "tarefa" a função da escrita poética, assim como da arte de um modo geral. Tendo tais questões em vista, podemos deduzir que estes Novíssimos que protagonizavam no referido contexto a cena poética de São Paulo, carregariam em comum com inúmeros poetas de todos os cantos do Brasil uma espécie de Zeitgeist que se infere da dicção particular de cada um.

A Pauliceia pela qual perambulavam os Novíssimos, contraditoriamente em relação a certas categorias provincianas e conservadoras, ${ }^{6}$ já ostenta status de metrópole, com intensa vida cultural. Nela confluem várias tendências artísticas, filosóficas e

\footnotetext{
${ }^{5}$ Cf. (KAFKA, 2003, p.237).

${ }^{6}$ Roberto Schwarz (1978) refere-se aos "tesouros da bestice rural e urbana" que viriam à tona com "As Marchas com Deus pela família e a Liberdade" evidenciando o caduco moralismo cultivado pelas elites e pela classe média paulistana temerosa da "ameaça comunista" que se esboçava durante o período do governo João Goulart.
} 
políticas. ${ }^{7}$ Cada vez mais desvairada, na esteira da crescente modernização e industrialização, a cidade é também ponto de convergência de costumes e línguas provenientes de todo o mundo, o que contribui para o cosmopolitismo favorável à efervescência de ideias que então se fazia presente. Sobre esse aspecto, Claudio Willer endossa:

\begin{abstract}
Nós éramos uma geração que, se for para contextualizar, estava dentro daquele ambiente que caracterizou o governo Juscelino Kubitschek, de desenvolvimento, de uma abertura, de uma internacionalização da economia. Sentíamos que São Paulo viria a se tornar uma metrópole, como de fato se tornou. Um lugar com uma espécie de diálogo ou de contato com o resto do mundo, e não aquela província que São Paulo era na época. Então, tínhamos essa abertura, esse cosmopolitismo de nos interessar pelo que acontecia no mundo todo e, evidentemente, por manifestações com uma dimensão crítica, que significassem algum tipo de ruptura ou subversão. ${ }^{8}$
\end{abstract}

Assim, entre outras evidências desse momento de abertura, as livrarias ofereciam obras ligadas ao que acontecia de mais recente e relevante em todo o mundo em termos de pensamento e criatividade. ${ }^{9}$ As leituras e informações difundiam-se, não raro, em debates e encontros, com opiniões professadas ou defendidas apaixonadamente em lugares como o Paribar, João Sebastião Bar, Ferro's e La Cremière, próximos à biblioteca Mário de Andrade, um dos principais espaços gregários dessa geração. Álvaro Alves de Faria relata assim “o encontro quase diário dos 'novíssimos' na escadaria da Biblioteca Municipal Mário de Andrade, à procura de livros". ${ }^{10}$

No início dos anos sessenta o modernismo brasileiro já fazia parte da percepção simbólica desta urbe. Sendo assim, seus poetas novos, inevitavelmente, relacionavam-se

\footnotetext{
${ }^{7}$ Sobre a São Paulo da época em que se dá a gênese da obra de Piva e Willer, conferir o documentário Uma Outra Cidade, de Ugo Giorgetti, com Antonio Fernando De Franceschi, Claudio Willer, Jorge Mautner, Roberto Piva e Rodrigo de Haro.

${ }^{8}$ Disponível em: http://www.revista.agulha.nom.br/ag34willer.htm.

${ }^{9}$ Cf. a entrevista de Claudio Willer, por Floriano Martins, na Espéculo UCM. Disponível em: http://www.ucm.es/info/especulo/numero13/c w ent.html. Diz o poeta, sobre o contato com uma de suas principais referências: "Éramos atualizados. Íamos comprando a obra completa do Artaud na Livraria Francesa à medida que os volumes saíam na França".

${ }^{10}$ Disponível em: http://www.alvaroalvesdefaria.com/\#/panorama-editorial/4529455500.
} 
com uma cidade não só de concreto, ferro, automóveis, indústrias e multidões - estavam diante da cidade escrita, principalmente por Mário de Andrade: criador da obra mais emblemática nesse sentido. 11 "Ler Mário", segundo Willer "era duplicar a vivência de São Paulo, frequentando também no plano do texto, os lugares por onde se transitava no cotidiano, assimilando sua visão poética do espaço urbano" (2000, p.229). Assim, no poema de abertura de Paranoia, primeiro e mais célebre livro de Roberto Piva, o modernista aparece como um guia inaudito, transfigurado pelo viés marginal e alucinatório que o eu lírico imprime à sua própria cosmovisão:

na solidão de um comboio de maconha Mário de Andrade surge como [um

Lótus colando sua boca no meu ouvido fitando as estrelas e o céu que renascem nas caminhadas

(“visão 1961”, Paranoia, 1963)

Há que frisarmos o poema "No parque Ibirapuera", também de Piva, cujo trecho transcrevemos abaixo, no qual o eu lírico espelha toda a carga de sua experiência no poeta modernista:

É noite nos teus poemas, Mário!

Onde anda agora a tua voz?

Onde exercitas os músculos da tua alma, agora?

Aviões iluminados dividem a noite em dois pedaços

$\mathrm{Eu}$ apalpo teu livro onde as estrelas se refletem como numa lagoa

É impossível que não haja nenhum poema teu escondido e adormecido no fundo deste parque

(...)

Quero que a Pauliceia voe por cima das árvores suspensa em teu ritmo

(Paranoia, 1963)

\footnotetext{
${ }^{11}$ Embora, como nos diz Claudio Willer (2000), não seja possível falar em atitude unânime em relação ao modernismo brasileiro, é inegável que a percepção modernista de São Paulo constitui elemento indissociável de alguns dos novíssimos como Carlos Felipe Moisés e Roberto Piva.
} 
Há, por parte do sujeito, consciência da cisão, de sua marginalidade e ao mesmo tempo desejo de seguir essa vivência como única possível. Como já foi dito por Mário Cámara, o modernista é aqui apresentado em seu caráter mais outsider, mais subterrâneo. É o Mário de Andrade homossexual, a figura erudita que se despoja para mergulhar no carnaval, pronto à devassidão de novas experiências: não é o monumento da inteligência brasileira que Piva faz figurar. É um "Virgílio Demoníaco” que “(...) abre las puertas de San Pablo para que el yo lírico inicie sus desplazamientos" (CÁMARA, 2010, p.29), guia revivido e recriado ao simples toque da leitura ao mesmo tempo crítica (pois que redefine, atualiza e acrescenta significado) e altamente subjetiva e apaixonada.

Mário, embora de modo menos notório, também é revisitado e marca presença intertextual na incursão de Willer pela cidade:

Assim foi que se dissociaram as parte do meu corpo: as vísceras emaranhadas na copa de um coqueiro, as mãos despenhadas em crateras, os pés calcados em um formigueiro em planície árida, a cabeça congelada e fixa em uma encosta, os olhos vidrados para sempre fitando o poente, os genitais perdidos na correnteza de algum rio que nunca chegará ao oceano, os pulmões arrastados por falcões insensíveis, os demais membros perdidos em tetos de edifícios ou então fincados em troncos milenares.

(“o vértice do pântano", Anotações pra um apocalipse, 1964)

A imagem do sujeito dividido em várias partes, cada uma existindo de modo autônomo, aponta evidentemente para a fragmentação e desagregação do indivíduo. Pode ainda remeter ao rito iniciático do xamanismo segundo o qual o candidato a xamã, lançado aos ínferos, é esquartejado pelos espíritos dos ancestrais para depois ser remendado pelos mesmos emergindo desta e de outras experiências de iniciação com os 
poderes de feiticeiro e curandeiro. ${ }^{12}$ Esse alucinatório relato willeriano não deixa, no entanto, de ecoar o famoso poema de Mário de Andrade:

Quando eu morrer quero ficar,

Não contem aos meus inimigos,

Sepultado em minha cidade,

Saudade.

Meus pés enterrem na rua Aurora,

No Paissandu deixem meu sexo,

$\mathrm{Na}$ Lopes Chaves a cabeça

Esqueçam.

No Pátio do Colégio afundem

O meu coração paulistano:

Um coração vivo e um defunto

Bem juntos.

Escondam no Correio o ouvido

Direito, o esquerdo nos Telégrafos,

Quero saber da vida alheia,

Sereia.

O nariz guardem nos rosais,

A língua no alto do Ipiranga

Para cantar a liberdade.

Saudade...

Os olhos lá no Jaraguá

Assistirão ao que há de vir,

O joelho na Universidade,

Saudade...

As mãos atirem por aí,

Que desvivam como viveram,

As tripas atirem pro Diabo,

Que o espírito será de Deus.

Adeus

(Lira paulistana, 1945)

Poderíamos dizer que o modernista é reescrito por Willer em outra perspectiva.

No poema deste, os pedaços cindidos do eu lírico não se ligam à cidade - todos os lugares onde estão os membros dissociados remetem ou a elementos da natureza, de fora da cidade, ou a um espaço de distanciamentos da experiência mais chão a chão da urbe (os tetos dos edifícios), além do que, se trata, no caso de Willer, de um

\footnotetext{
${ }^{12}$ O xamanismo e as técnicas arcaicas do êxtase (ELIADE, 2002).
} 
estilhaçamento existencial que se define como modo de viver e não como persistência póstuma, repleta de humor e ironia, da relação com certa experiência urbana como podemos depreender em Mário. Palimpsesto de sangue, vozes, concreto e multidões, a cidade uma vez escrita pode ser reescrita.

Voltando aos focos de convivência, é imprescindível destacar além dos bares, livrarias e da biblioteca, a casa do filósofo Vicente Ferreira da Silva, espaço que conduz a aspectos centrais da poesia de Piva e Willer. O pensador e sua esposa, a poeta Dora Ferreira da Silva, recebiam os autores pertencentes a esta geração em saraus, discussões e grupos de estudo nos quais sobressaem debates de cunho existencial e metafísico, temas que então residiam no centro das preocupações dos neófitos. É o que podemos ver na entrevista de Rodrigo de Haro publicada na edição comemorativa de dez anos da revista Azougue (2004):

O convívio com Dora e Vicente Ferreira da Silva foi muito marcante para a nossa geração. A visão panteísta do mundo, um sentimento aristocrático do ser, impregnavam o convívio na casa acolhedora da Rua José Clemente. (...) Em torno de Vicente se reunia um grupo muito eclético, onde até o alto clero se fazia representar. Para Vicente, o inferno podia existir, mas certamente estaria vazio. Costumava dizer: "O mal é extremamente difícil" (HARO, 2004, p.300).

Como já foi apontado, ${ }^{13}$ em Quizumba, de 1983, Piva menciona o convívio com Dora e Vicente Ferreira da Silva. Vale ressaltar o modo como tal experiência de compartilhamento e busca pelo saber constituem elemento excepcional na memória afetiva do eu lírico:

quando garoto eu me impressionei com o estudo de Lawrence sobre

\footnotetext{
${ }^{13}$ Em: CHAVES, Reginaldo Sousa. FLANAR PELA CIDADE-SUCATA COMPONDO UMA ESTÉTICA DA EXISTÊNCIA: Roberto Piva \& seu Devir Literário Experimental (1961-1979). Dissertação de mestrado. Orientador: Edwar de Alencar Castelo Branco. Universidade Federal do Piauí, 2010, (p.31).
} 


\author{
Edgar Allan Poe \\ nunca mais esqueci \\ assim como não esqueci Ferreira da \\ Silva e nossas leituras de \\ Sein und Zeit.
}

Em Ciclones, de 1997, Piva parece aludir mais uma vez a essas sessões de leitura e estudo, ao comentar o texto do filósofo de Ser e Tempo sobre a essência da poesia, cujo objeto é um de seus poetas prediletos: "Heidegger/ quando escreveu sobre Trakl/ era um dia assim/ com este vento devasso/ entre o crepúsculo/ \& o renascimento" (1997, p.42).

Willer também atesta a importância crucial dessa experiência para sua formação. Relata, assim, como na casa de Dora e Vicente veio a ter contato com leituras essenciais para sua poesia e ensaística. Semelhante ao que acontece com Piva (que teria sido o primeiro a falar sobre o casal para o amigo, comentando entusiasticamente um poema de D. H. Lawrence traduzido por Dora), há galvanização - o encontro ratifica a vocação do poeta iniciante e a intensifica:

Passei a frequentá-los, a Dora e Vicente. Entre Artaud e Lawrence (fui comprando sucessivos volumes de sua obra nas edições da Penguin), quanta coisa: Rilke, é claro, Mircea Eliade, Eliot, Saint-John Perse. O encantamento das descobertas. Com Vicente, participei de um grupo de leituras de Heidegger - os ensaios sobre Hölderlin, Van Gogh e a essência da arte - junto com Antonio Fernando de Franceschi e Carlos Jaquieri. Dora falava-me sobre Isis e Osíris, sobre Dionísio, sobre ritos chineses de sagração da fertilidade, sobre... Mostrei-lhe poemas. Observou onde havia rebarbas que podiam ser aparadas. Estreei em letra impressa em Diálogos: uma tradução de um conto de Lawrence que ela me propôs, Overtones, Ressonâncias, e dois poemas meus. ${ }^{14}$

Pode-se depreender das referências mencionadas por Willer tópicos significativos como a preocupação metafísica (Rilke), o interesse pelo sentido e poder

\footnotetext{
14 "Encarnações da poesia" - depoimento em homenagem a Dora Ferreira da Silva, por ocasião de sua morte em 2006. Disponível em: http://www.revista.agulha.nom.br/cw1.html.
} 
dos mitos (Eliade), a visão fragmentária e crítica da modernidade (Eliot), a angústia cósmica do sujeito moderno (Saint John Perse), a procura pela essência da linguagem e da arte concernente ao sentido do ser (Heidegger), o ímpeto encantatório e rebelde frente à realidade utilitária do mundo burguês - marcada, neste caso específico, pelo acento trágico da loucura (Hölderlin, Artaud, Van Gogh); ${ }^{15}$ e ainda, o interesse por outras culturas, cosmogonias e formas de pensamento com ênfase no orientalismo e no paganismo. Ora, tais elementos projetam até certo ponto algo do espírito de época que vigorava na "Humaníssima, pícara, um pouco escatológica"16 São Paulo de então.

É importante mencionar também a vida musical da cidade, com destaque para os bares e o Hotel Cambridge onde músicos como Johnny Alf executavam a bossa nova, que sempre exerceu especial fascínio em Piva e cuja proposta estilística reflete a euforia e espírito inovador que se vivia no Brasil, com a nova capital recém-inaugurada e o clima de abertura e internacionalização a fervilhar cada vez mais. Nessa perspectiva eram devorados os produtos da ascensão do cinema europeu do pós-guerra: presenças que emolduram, em certa medida, o panorama da experiência até aqui apresentada. Ao falar da importância que tiveram no ambiente dos novíssimos filmes como $O$ Acossado, de Godard; A doce Vida, de Fellini; Rocco e seus irmãos, de Visconti, Willer frisa que: "Essas obras mostravam vidas, inquietações e rebeliões em que se espelhavam jovens de classe média entre os quais prevalecia um difuso existencialismo.” A identificação com tais personagens esboça, nesse sentido, uma forma de viver apta a canalizar as angústias dos jovens poetas em foco. Assim, no importante posfácio à Antologia poética da geração de 60 (2000) organizada por Carlos Felipe Moisés e Álvaro Alves de Faria,

\footnotetext{
${ }^{15}$ Temos consciência das circunstâncias históricas que diferenciam os três artistas em questão. No entanto, é notório o embate de cada um com o racionalismo e o utilitarismo que marcaria a civilização ocidental desde o Iluminismo. Assim, também é necessário lembrar como o antidiscursivo, o sentimento de cisão, fragmentação e perda que caracterizam Hölderlin se identificam, não raro, muito mais com a experiência de Artaud e Van Gogh, do que com a de seus contemporâneos propriamente ditos.

${ }^{16}$ Segundo Rodrigo de Haro no depoimento acima citado.
} 
Willer acrescenta que "Em toda estante um pouco mais cultivada, encontravam-se exemplares de A Náusea, de Sartre, A Peste de Camus" (2000, p.211).

Este cenário é também caracterizado pelo clima de mobilização e pela crise política que marcam o período referente à "era Jango", alcunha do governo João Goulart (1961/1964) cuja problemática explicitava conflitos ideológicos entre conservadores e progressistas. Como afirma Roberto Schwarz, os rumos a serem tomados pelo Brasil estavam na pauta do dia, "O país vibrava e as suas opções diante da história mundial eram pão diário para o leitor dos principais jornais" (SCHWARZ, 1978, p.64). Nesse âmbito dava-se a reorientação das esquerdas e a movimentação que se refletia em iniciativas como o método Paulo Freire de alfabetização de adultos, ${ }^{17}$ os urros de protesto do Cinema Novo, o teatro político encenado no campo e nas indústrias pelos Centros Populares de Cultura, entre vários outros sintomas deste momento de entusiasmo. Assim, como afirma Schwarz, o "vento pré-revolucionário", que "descompartimentava a consciência nacional e enchia os jornais de reforma agrária, agitação camponesa, movimento operário, nacionalização de empresas americanas" (p.69), era sentido em vários níveis. Havia uma atmosfera de tensões e de decisões a tomar por parte dos produtores da cultura. Para usar um termo corrente: ao poeta, como "antena da raça", seria impossível indiferença diante de tais circunstâncias. Nessa perspectiva as posições a respeito da palavra poética tinham relação direta com os destinos do país. ${ }^{18} \mathrm{O}$ foco era a possível eficácia e o provável papel da poesia diante dos acontecimentos.

Em meio a essa efervescência cultural e agitação política, artística e filosófica os debates a animar o panorama intelectual voltavam-se de um lado para empreendimentos

\footnotetext{
${ }^{17}$ Cf. O golpe na educação, de Luiz Antonio Cunha e Moacir Góes (1991).

${ }^{18}$ Como podemos ver em Impressões de viagem: CPC, Vanguarda e desbunde: 1960/70, de Heloísa Buarque de Hollanda (1992).
} 
como o concretismo e poesia práxis (com diferentes concepções do processo de escrita, nas quais convergem ideias voltadas para uma poesia de invenção com ênfase na problemática formal) andando par a par com a euforia técnico-industrial característica do período do governo Kubitschek (1955-60); de outro, para o polo da militância, direcionado para uma mensagem política direta, calcada no ideário marxista, cujas manifestações encontram-se nos poetas integrados a projetos como os da antologia Violão de Rua e as demais atividades ligadas ao CPC (Centro Popular de Cultura). Havia ainda a presença dos remanescentes da geração de 45, com uma poesia universalista em que se evidencia o exacerbado esteticismo sob o ponto de vista classicizante.

Willer, em ensaio publicado na revista CULT n. 76 (2004), faz um balanço de sua geração. Observa que os Novíssimos não eram "nem formalistas, nem conteudistas; nem militantes ortodoxos, nem trancafiados em torres de marfim" (p.10). Relata diferenças e afinidades dos poetas de Massao Ohno com as tendências em voga. Para eles:

A relação com os de 45, que dominavam o panorama cultural era ambivalente. Houve quem fosse adotado como sucessor. E quem a combatesse. Poesia concreta, sim, era unanimidade negativa. Para muitos, em nome da permanência do verso. Por serem engravatados, bem-comportados. Por entenderem que, com as novas tecnologias, informática etc., viria uma nova linguagem, em forma de ideograma. (p.55)

Percebe-se que a divergência com os concretistas, tanto no caso de Willer como de seus coevos remete ao fato de identificarem como princípios do Noigrandes elementos que vão de encontro à poesia e ao comportamento cultivado por muitos do grupo, além da monopolização taxativa do epíteto vanguardista com o qual, a seu modo, alguns da geração de Piva e Willer também se relacionavam. No entanto, a busca por 
novas categorias ou percepções, quando ocorre, por parte de integrantes dos Novíssimos

(Como os próprios poetas sobre os quais este trabalho se debruça), se dá a partir da subjetividade, não se desliga das questões inerentes ao $e u$. É nesse sentido que Willer atenta para a tendência mais ou menos homogênea entre os autores de Massao Ohno. Uma concepção radicada nas origens da lírica, à revelia de processos inovadores ou compromissos ideológicos. Assim, os Novíssimos, segundo Willer, teriam em comum:

(...) a volta à poesia do "eu", ${ }^{19}$ a poesia na primeira pessoa. O poeta engajado, dentro da estética nacional-populista, não está falando da subjetividade dele: está falando das grandes lutas sociais. O poeta formalista também não fala dele: o sujeito, o "eu", está abolido em qualquer concepção formalista (...). ${ }^{20}$

Tal aspecto era provavelmente visto como impropriedade artística pelos concretos que reivindicavam "realismo total. Contra uma poesia de expressão, subjetiva e hedonística." (CAMPOS, 1975, p.158). Para o grupo em questão, categorias como "novo" ou "vanguarda", tinham por correlato o desenvolvimento econômico e tecnológico da sociedade. O poema seria um objeto útil, engendrado via cálculo, controlado minuciosamente em suas possibilidades de efeito e funcionamento no plano das atividades sociais. É no intento de produzir tal obra que desempenham sua leitura da tradição, quando buscam seus precursores em poetas como Apollinaire, Mallarmé, Cummings e formulam seu "paideuma". ${ }^{21}$

\footnotetext{
${ }^{19}$ Obviamente Willer se refere às circunstâncias paulistanas, então dominadas pelo debate entre os representantes do que seria a vanguarda e aqueles que defendiam uma mensagem revolucionária, a fim de converter as massas; contando ainda com o fato de que os de 45 valorizavam uma escrita cujo propósito era obliterar os impulsos subjetivos (considerados ingênuos). Mas sempre se escreveu poesia por todos os cantos do país: um poeta como Nauro Machado encontrava-se em plena atividade e não tinha como programa a abolição do sujeito poético. Havia poetas do modernismo, como o próprio Drummond, que estavam na ativa e se dedicavam ao tema da memória, a questões intimistas ao mesmo tempo em que faziam experimentos formais com total liberdade.

${ }^{20}$ Disponível em: http://www.revista.agulha.nom.br/ag34willer.htm.

${ }^{21}$ Segundo o poeta-crítico norte-americano Ezra Pound: "a ordenação do conhecimento de modo que o próximo homem (ou geração) possa achar, o mais rápido possível, a parte viva dele e gastar um mínimo de tempo com itens obsoletos". (POUND, 2006, p.161).
} 
O grupo formado inicialmente pelos irmãos Augusto e Haroldo de Campos e Décio Pignatari buscava, em suas incursões críticas, tanto o mergulho no passado como naquilo que havia de mais atualizado em termos de linguagem. Desse modo, o Noigrandes propunha-se a "colher no ar uma tradição viva" (p.29). Tal proposta enunciada por Ezra Pound, farol fundamental para os horizontes concretistas, consistiria em elencar uma série de poetas cujos processos inovadores em sua época dariam a conhecer os pressupostos mais relevantes para a produção atual, descartando o que fosse obsoleto e respaldando os moderníssimos princípios dos autores do presente. Nessa perspectiva, a plataforma iconoclasta se validaria por alcançar o estágio mais adiantado e funcional da possibilidade de invenção e intervenção desta na História.

Vemos entre os grupos de poetas que compõe o panorama dos Novíssimos que estes (de modo declarado ou não) cultivam também uma forma de pesquisa estética. No depoimento de Antônio Fernando De Franceschi mencionado acima, o autor fala da multiplicidade de diálogos desses poetas com a tradição, citando os escritores "para os quais a atenção de muitos convergia. Pessoa e Drummond, por exemplo, ou, para uma certa parte do grupo, Villon, Baudelaire e Rimbaud. Ou ainda para outros os surrealistas e os poetas americanos da beat generation" (1991, p.63). Refere-se ao "ecletismo de base nessa constelação literária”. Haveria, portanto, entre os poetas de Massao Ohno, diferentes paideumas.

Nesse sentido uma possível ideia de grupo desfaz-se diante da evidência de uma soma de individualidades dividida em vários subgrupos a partir das afinidades eletivas a fomentar iniciativas como aquelas do "Sermão do viaduto" de Álvaro Alves Faria, da "Catequese poética" de Lindolf Bell e da "poesia na praça" de Neide Archanjo e Eunice 
Arruda. ${ }^{22}$ É dentro dessa aglutinação multifacetada que podemos identificar a vertente integrada por Piva e Willer. Este último, no posfácio à referida Antologia dos Novíssimos (2000) cunha a expressão "Periferia Rebelde",23 para nomeá-la. Ao caracterizá-la, refere-se aos "diferentes graus de afinidade com o Surrealismo e a geração Beat" (2000, p.227) por parte de seus integrantes, representados por escritores como Sérgio Lima, Décio Bar, De Franceschi, Roberto Bicelli, Rodrigo de Haro e os poetas que aqui constituem nosso objeto de estudo. ${ }^{24}$ Entre Piva e Willer, em particular, é possível perceber maiores semelhanças, pelo fato de que fundam suas obras poéticas sobre os mesmos pilares: é nos dois, como pretendemos mostrar, que se adensa o íntimo mergulho nos movimentos mencionados - definem-se a partir do diálogo com beats e surrealistas os contornos de determinada visão romântica, fundada, sobretudo, no princípio da analogia; que se direciona (em especial) para os conteúdos do inconsciente com ênfase na subjetividade anárquica e no erotismo (guardando as escalas, tons e as motivações de cada um), como forma de cultivar certo slogan transgressivo.

A condição marginal, periférica, então encarnada por esses poetas impõe-se, como uma das pedras fundamentais de suas vozes criativas e ponto de partida para uma especial concepção imagética que se manifesta em suas obras. Explicita-se aí o desejo de perverter a lógica e a razão instrumental - o que se pode depreender do contraponto que nossos poetas estabelecem em relação aos concretos.

\footnotetext{
${ }^{22}$ Note-se a dimensão oral e pública da poesia perceptível no nome dessas manifestações.

${ }^{23}$ Cf. NOYA, Thiago de Almeida. Roberto Piva e a "periferia rebelde". Dissertação de mestrado. Orientador: Ítalo Moriconi. Universidade do Estado do Rio de Janeiro, 2004.

${ }^{24}$ Sobre as peripécias e aventuras e contravenções do grupo Cf. D’ELIA, Renata. HUNGRIA, Camila. Os dentes da memória - 'Piva, Willer, Franceschi, Bicelli e uma trajetória paulista de poesia'. Rio de Janeiro: Azougue Editorial, 2011.
} 
Assim, as obras completas de Piva, reunidas em três volumes, nos quais constam os livros Paranoia (1963), Piazzas (1964), ABRA OS OLHOS E DIGA AH! (1975), Coxas (1979), 20 poemas com brócolis (1981), Quizumba (1983), Ciclones (1997) e Estranhos sinais de Saturno (2008), ostentam uma espécie de inventário de transgressões, que embora se transforme, dando-se a diversos experimentos ao longo do tempo, é sempre cosido pelo fio da imagem poética.

Nessa perspectiva (e levando em consideração o diálogo criativo empreendido com Piva) a obra do poeta-ensaísta e tradutor Claudio Willer, cujos poemas encontramse quase todos reunidos no volume Estranhas Experiências (2004), cultiva também a predileção pelo imagético e pela linhagem transgressiva da criação literária. É o que podemos ver em Anotações para um Apocalipse (1964), Dias Circulares (1976), Jardins da Provocação (1981) e nos poemas inéditos de Estranhas Experiências. É importante assinalar que a ensaística de Willer permeia toda sua produção - sendo que seus três primeiros livros vêm acompanhados de ensaios-manifestos essenciais à compreensão de seu ideário. Nesse sentido destacam-se também a narrativa em prosa Volta (1996), os ensaios Geração Beat (2009), Obscuro Encanto (2010), ${ }^{25}$ assim como sua atuação na revista eletrônica Agulha, que coeditou com Floriano Martins (de 1999 a 2009), e as traduções de Os Cantos de Maldoror de Lautréamont, Escritos de Antonin Artaud e Uivo, Kaddish e outros poemas de Allen Ginsberg.

Um entusiasmo pela poesia associada à experiência de exceção parece ter sido o elemento constitutivo dessa "Periferia Rebelde" na qual Piva e Willer compartilharam a vivência geracional que está nos anos de formação da personalidade poética de ambos. Tal perspectiva alia-se a uma relação peculiar com a leitura e com referências, alusões

\footnotetext{
${ }^{25}$ Primeiramente apresentado como Tese de Doutoramento no Departamento de Teoria Literária e Literatura Comparada na Faculdade de Filosofia, Letras e Ciências Humanas da Universidade de São Paulo (2008) do DLCV.
} 
ou diálogo constantes com outros autores. O poema "A Princípio" de Claudio Willer, presente em seu livro Jardins da Provocação (1981) remete a essa fase. O arrebatamento lírico é notório:

então eu estava bêbado e intoxicado de García Lorca

havia lido relido treslido Poeta em Nova Iorque Divã do Tamarit Odes Pranto para Ignacio Sanches Mejía Bodas de Sangue Bernarda Alba

eu vivia santificado escrevia aberrações e enormidades

as plantas dissolviam-se em éter as fascinantes plantas carnívoras (...) abrindo-se palpitantes de vida

nós construímos a década de sessenta: uma ruptura incandescente e a partir daí tudo começou a jorrar e ainda era pré-histórico e larvar a palavra iluminava a realidade deslizando pelos cantos do quarto

a cena se repete e é sempre a mesma coisa em 1965 eu pensava em suicidar-me debruçado sobre a noite gelada escrevia sem parar e invocava fantasmas os amigos: Piva Maninha Bicelli Décio Rodrigo e tantos outros (“A princípio", Jardins da provocação, 1981).

É interessante notar como o eu lírico pretende fazer o literário fundir-se, confundindo-o (extático núcleo) com o vivido, gerando percepção diferenciada do real deseja-se desvelar o mundo por meio da palavra poética e a partir daí engendrar experiências, enriquecer em perspectiva simbólica o que passa pela pele, penetra nos poros (ali borbulha como lava) e transmuta-se em memória-erupção. O tom exaltado da confissão, a intimidade com que o eu lírico invoca ao mesmo tempo nomes de pessoas com as quais teria compartilhado sua experiência geracional e títulos de livros, remete à natureza gregária da geração beat, tal como evidenciada em poemas como "Uivo" de Allen Ginsberg, cuja "nota de rodapé" tem também a perspectiva (que certamente 
inspirou seu leitor e tradutor Claudio Willer) de sacralizar uma confraria específica, dando à mesma, pela via poética, o papel de protagonista do momento histórico intensamente vivido por um viés marginal. Assim, os coevos willerianos aparecem de modo análogo aos escritores-personagens da beat no poema de Ginsberg:

A máquina de escrever é santa o poema é santo a voz é santa os ouvintes são santos o êxtase é santo!

Santo Peter santo Allen santo Solomon santo Lucien santo Kerouac santo Huncke santo Burroughs santo Cassady santos os mendigos desconhecidos sofredores e fodidos santos os horrendos anjos humanos!

Santa minha mãe no asilo de loucos! Santos os caralhos dos vovôs de Kansas!

Santo o saxofone que geme! Santo o apocalipse bop! Santos a banda de jazz marijuana hipsters paz \& droga \& sonhos!

(“Uivo", 1956).

Na apresentação da coletânea Estranhas Experiências (2004) Willer discorre sobre este período e seu caráter grupal, ligando-o inextrincavelmente à gênese de seus poemas. Segundo o autor, sua obra nasceria do "denso caldo de cultura dos grupos de poetas jovens em São Paulo, por volta de 1960" (p. 47). Menciona assim a importância das sessões de leitura "em voz alta, uns para os outros, Fernando Pessoa, Jorge de Lima, o restante do melhor modernismo de língua portuguesa, dos demais modernismos e do surrealismo" (p.09). "Éramos uma câmara de ecos de poesia, e prosa, e filosofia", expõe Willer, salientando que nessas circunstâncias "Dois ângulos ou duas perspectivas para apreender o que vem a ser liberdade de expressão e criação" eram "as leituras sincrônicas, quase simultâneas, de Os Cantos de Maldoror de Lautréamont e de Uivo e Kaddish de Ginsberg", pois "Se havia quem escrevesse daquele jeito, então tudo era permitido" (2004, p.09). 
A excitação do grupo para com esses textos, e muitos outros, faz-se ver no depoimento de Antonio De Franceschi à Azougue 10 anos no qual poeta comenta um episódio em que, num bar da Alameda Glete, juntamente com Piva e Décio Bar leram “de uma enfiada só o Poeta em Nova York” de Garcia Lorca. (2004, p.36). Relata desse modo o significado das leituras em voz alta para o grupo:

Era uma coisa absolutamente natural, uma forma de convivência. Era impossível algum de nós descobrir alguma coisa importante sem comunicar e imediatamente aliciar os outros para a leitura. Havia um traço de generosidade nessas partilhas ampliadas e o Piva sempre foi o maior aliciador. É claro que se tratava de uma forma de ratificação de nossas escolhas. A consolidação das experiências individuais se dava por sua socialização, que era o cimento do grupo. Era importante para nós que aquela voz que havia nos mobilizado tanto também estivesse a serviço do outro. (p.35)

Também Rodrigo de Haro nos mostra um retrato interessante do modo como se dava a relação com o conhecimento por parte desses poetas, ao falar, sobre Willer, que:

(...) o seu apartamento na Major Quedinho era então o abrigo, no sentido mais literal, de uma legião tebana de ígneos saídos em busca do Graal da realização literária (...) Enquanto às suas costas alguma dupla ensandecida experimentava variantes de golpes mortais de espada, à maneira da Escola de Edo, ou de qualquer outra - pois estávamos na época áurea de Reinosuke Gosho e Tomu Ushida - Claudio, impassível, debruçado na mesa de trabalho (uma enorme mesa escura e episcopal, com pés de bolacha, pesada de tantas pilhas de papel), continuava tranquilamente uma tradução de Ângelus Silesius. (HARO, 2004, p.301, 302).

Pode-se perceber que tal troca de informações acentuada pelo ímpeto vitalista é marcante desde os primórdios da amizade entre Piva e Willer. Conheceram-se por volta de 1959/60. Willer, já tendo ouvido algo sobre aquele rapaz irreverente, desregrado e ao mesmo tempo bastante culto, convidou-o para participar de um grupo de audição de música erudita - os interesses focados principalmente em compositores românticos. Logo após, pela iniciativa daquele que em breve traria a lume Paranoia, organizaram, 
com mais alguns aficionados, um ciclo de debates sobre poesia. Dá-se assim o início de uma interação contínua em que se destaca aquele "traço de generosidade" nas "partilhas ampliadas" nas quais Piva destaca-se como "o maior aliciador".

A imagem de Roberto Piva como proliferador de informação, de poesia, tem os traços apaixonados do portador da boa nova - profeta louco embebido em seu evangelho do caos - voz estrondosa, forjada às flamas de um fluxo que busca integração - na dança tentacular do desejo, pois sua fome por leituras e por vivências novas e dissonantes para com a mediocridade vigente se espalha pelos quatro ventos, disseminando a rebelião, como o visionário de Ginsberg que anuncia ser a hora da "Profecia sem morte como consequência". Como nos diz a escritora e psicanalista Maria Rita Khel, quando Piva:

\begin{abstract}
“(...) simpatizava com alguém, quando vislumbrava através de todas as aparências em contrário um possível aliado, costumava acionar sua poderosa máquina aliciadora sem pudor e sem limites. Precisava de aliados como de amigos e de amantes. Não queria formar um partido e sim uma legião. De anjos terríveis". ${ }^{26}$
\end{abstract}

Tal é a perspectiva sob a qual se deu a aproximação de nossos poetas. Assim, Willer ressalta a importância de Piva no sentido de indicar-lhe leituras essenciais para sua formação. O que se percebe é que tal papel se exerce a revelia de qualquer comprometimento, conduz essa partilha o afeto, o entusiasmo e o imperativo de engendrar focos de sobrevivência frente à normalidade triunfante. É como se os textos tivessem uma energia redentora, que se quer ver espalhada, linguagem-vírus pronta para arrebatados tumultos. É desse modo que, como nos relata Willer,

(...) Seu entusiasmo resultava em telefonemas para sugerir leituras, escolhidas com uma precisão antecipatória: "Olha, você tem que ler $A$

\footnotetext{
26 "Há método em sua loucura". Texto publicado no jornal Estadão em 10 de julho de 2010, por ocasião do falecimento de Roberto Piva. Disponível em: http://www.estadao.com.br/noticias/impresso,hametodo-em-sua-loucura,579155,0.htm.
} 
função do orgasmo de Wilhelm Reich", "Tem um livro importante, $E l$ arco y la lira, de Octavio Paz, não deixe de ler. E ia citando trechos para ilustrar seus comentários. (2005, p.144-145)

O caráter frenético que caracteriza o diálogo entre nossos poetas, pode ser notado em outro trecho do relato de Willer. O personagem piviano, sorte de figura excêntrica daquela São Paulo do início dos anos sessenta, não se dissocia das referências das quais se cerca. Encarna seus poetas amados, utiliza-se de suas obras como mapas para um delírio ávido por desmantelar a opaca realidade:

Era comum perambular pela cidade, em sua versão da flânerie baudelairiana, segurando um livro. Encontrando algum amigo, abria-o para ler trechos e comentá-los. Ou então, citava de memória, como certa vez em que o encontrei na Rua Major Sertório - pegou-me pelo braço e se pôs a recitar, do Poeta em Nova York de Garcia Lorca: Debaixo das multiplicações/ Há uma gota de sangue de pato/ debaixo das divisões/ há uma gota de sangue de marinheiro/ debaixo das somas, um rio de sangue terno!(WILLER, 2005, p.144)

Essa dimensão comunitária da poesia como fermento da cumplicidade, como vivência compartilhada, alheia à quietude e ao isolamento é perceptível em algumas passagens de poemas de Piva da mesma época e se faz ver na ênfase sonora, na coloquialidade que confere a aparência de relato, testemunho de coisas vividas:

meu pequeno estúdio invadido por meus amigos bêbados

\section{(...)}

uma avenida sem nome e uma esferográfica Parker nos meus manuscritos

\section{(...)}

meus livros flutuam horrivelmente

brinca de profeta no parapeito meu melhor amigo

("Poema lacrado", Paranoia, 1963); 
eu tomava sopa aguardando meus amigos desordeiros no outro lado da noite

(...)

(“Poema da eternidade sem vísceras", Paranoia, 1963);

nos pavimentos isolados meus amigos constroem um manequim [fugitivo

(...)

("Boletim do mundo mágico", Paranoia, 1963);

eixos titânicos montados na mente onde a heterossexualidade quer nos comer vivos

(...)

sobre os pavimentos desolados o firmamento está distante como nunca nós provamos a esperança desesperada que acompanha cada gesto [ritual

enquanto nossas tripas agonizam nos indefesos caules das hortênsias

(“L'ovalle delle apparizioni”, idem);

Dessa forma o contraponto da extravagante confraria composta pelos companheiros de aventuras estéticas, existenciais ou até sexuais, em relação à ordem social dominante, mostra-se constantemente como traço de uma ética superior. A verve anárquica e anticristã faísca nestes momentos em que o eu lírico define quem é; com quem anda e o que, especificamente, detesta:

Saltimbancos de Picasso conhecendo-se numa viela maldita e os ruídos agachavam-se nos meus olhos turbulentos resta dizer uma palavra sobre os roubos enquanto os cardeais nos saturam de conselhos bem-aventurados e a Virgem lava sua bunda imaculada na pia batismal

$(\ldots)$

(“Poema de ninar para mim e Brueghel”, Paranoia, 1963);

onde o nosso desprezo fez nascer uma lua inesperada no horizonte branco 


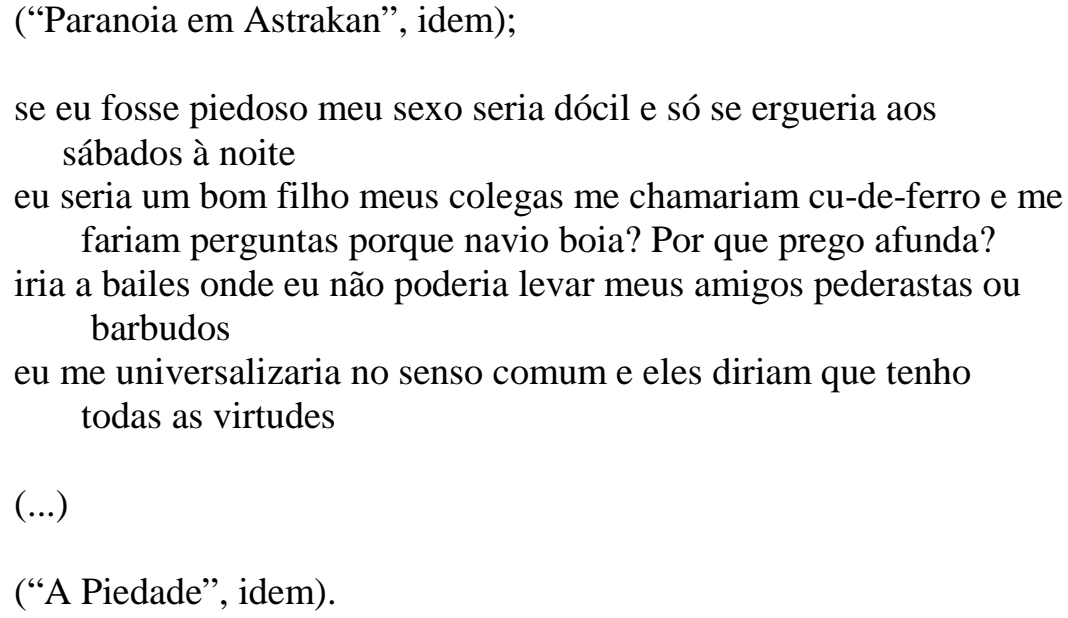

Willer, na sua poesia posterior à década de sessenta, debruça-se, por vezes, sobre o significado de tais vivências. É pela lembrança, que revisita e busca ratificar as situações experimentadas em grupo - este abandonar-se, deixar-se levar da poesia, que revela o desejo de depurar vicissitudes da vida pelo viés da imaginação - figura como um brilho inaudito, luz da memória com a qual o sujeito se devolve a si mesmo diante da banalidade perversa e fosca do cotidiano:

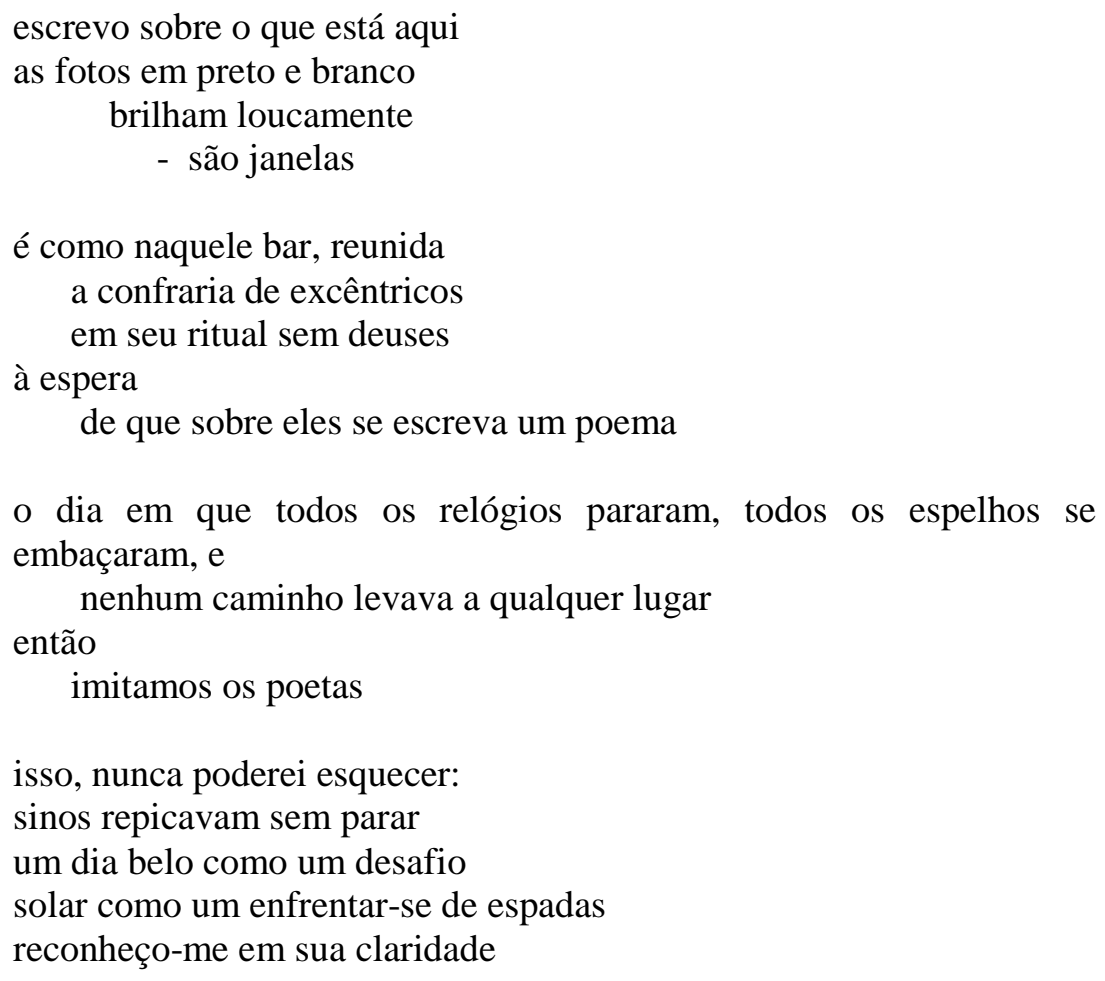


O poético feito celebração, pão maldito com que se comunga a liberdade, almejaria restituir ao eu uma vivência tribal que lateja inconsciente? Talvez nessa partilha figure a saudade imemorial que o sujeito moderno, sufocado pelo individualismo autômato das grandes cidades, teria da experiência da palavra contígua à coisa que nomeia. Palavra-participação, por meio da qual se sente viver e estar no mundo.

No posfácio ao primeiro volume das obras completas de Piva, Um estrangeiro na Legião (2005), Willer refere-se ainda ao Roberto Piva leitor de Nietzsche e Rimbaud, como alguém que "Manejava essas leituras" contra o que denominavam "genericamente de burguesia, e seus fundamentos - o cristianismo, o racionalismo cartesiano, a instituição da família, a ideologia do trabalho" (p.145). A relação descrita pelo amigo pode ser vista de modo especial quando o autor de Paranoia dirige-se ao protagonista dos Cantos de Maldoror de Lautréamont. Neste "Poema Submerso", com a intimidade do iniciado (neófito que acaba de conquistar seu espaço numa confraria) o eu poético nos mostra sua visão desvelada e sua vocação sancionada pelo poeta maldito:

Eu era um pouco da tua voz violenta, Maldoror quando os cílios do anjo verde enrugavam as chaminés da rua onde eu caminhava

E via tuas meninas destruídas como rãs por uma centena de pássaros fortemente de passagem

Ninguém chorava no teu reino, Maldoror, onde o infinito pousava na palma da minha mão vazia

E meninos prodígios eram seviciados pela Alma ausente do Criador

Havia um revólver imparcialíssimo vigiado pelas Amebas no telhado roído pela urina de tuas borboletas

Um jardim azul sempre grande deitava nódoas nos meus olhos injetados

Eu caminhava pelas aleias olhando com alucinada ternura as meninas na grande farra dos canteiros de insetos baratinados

Teu canto insatisfeito semeava o antigo clamor dos 
piratas trucidados

Enquanto o mundo de formas enigmáticas se desnudava

para mim, em leves mazurcas

(Paranoia, 1963).

Podemos ver que as imagens de horror e insatisfação (como "as meninas trucidadas como rãs" ou os "meninos seviciados pela alma ausente do criador") figuram como algo feliz, prazeroso, pois a violência e destrutividade a que o eu lírico alude, quando transfiguradas pela poesia, representam libertação dos instintos pela via simbólica: sublimação. Ecoam o estado de espírito do sujeito, canalizam seu grito ao mostrar que este se insere em uma tradição ("o antigo clamor dos piratas trucidados"), sendo assim, não está sozinho. Sua condição de estrangeiro se faz (ladeira lenta em que os caminhos se fundem) uma visão privilegiada da existência. Seu descompasso diante do mundo, ou da ordem estabelecida tem um correspondente estético, que é também posicionamento político, posto afirmar seus valores contra a realidade pela qual se sente oprimido.

Em Ode a Fernando Pessoa (1961), também de Piva, o trato com a literatura segue senda semelhante, denunciando, como no poema acima, algo da mesma natureza do que temos na passagem de Willer em que se diz que "a palavra iluminava a realidade/ deslizando pelos cantos do quarto". São visões fundamentadas, certamente, nos mesmos princípios. Esboçam uma espécie de orgia por meio do verbo dada por uma crença muito entusiasmada no poder da palavra poética. Percebemos isso na efusão vocativa, com referências ao sagrado, voltada para o Fernando Pessoa-Álvaro de Campos, provavelmente aludindo a esta Saudação a Walt Whitman, deste poeta, cujo trecho transcrevemos abaixo a título de comparação com o poema de Piva: 
Pertenço à tua orgia báquica de sensações-em-liberdade,

Sou dos teus, desde a sensação dos meus pés até à náusea em meus [sonhos,

Sou dos teus, olha pra mim, de aí desde Deus vês-me ao contrário:

De dentro para fora... Meu corpo é o que adivinhas, vês a minha alma

Essa vês tu propriamente e através dos olhos dela o meu corpo -

Olha pra mim: tu sabes que eu, Álvaro de Campos, engenheiro,

Poeta sensacionista,

Não sou teu discípulo, não sou teu amigo, não sou teu cantor,

Tu sabes que eu sou Tu e estás contente com isso!

Nunca posso ler os teus versos a fio... Há ali sentir demais...

Atravesso os teus versos como a uma multidão aos encontrões a mim,

E cheira-me a suor, a óleos, a atividade humana e mecânica.

Nos teus versos, a certa altura não sei se leio ou se vivo,

Não sei se o meu lugar real é no mundo ou nos teus versos,

Não sei se estou aqui, de pé sobre a terra natural (...).

(PESSOA, 1986, p.337).

Em Piva, o mesmo verso laudatório, a mesma batida frenética e emotiva:

Ó mestre da Plenitude da vida cavalgada em Emoções,

Eu e meus amigos te saudamos!

(...)

Nós, tenebrosos vagabundos de São Paulo, te ofertamos em turíbulo [para uma

Bacanal em espuma e fúria

(...)

Fernando, vamos ler Kierkegaard e Nietzsche no Jardim Trianon pela manhã,

enquanto as crianças brincam na gangorra ao lado

Vamos percorrer as vielas do centro aos domingos quando toda a gente decente

[noite

dorme, e só adolescentes bêbados e putas encontram-se na

Vamos viver para além da burguesia triste que domina meu país alegremente

Antropófago.

(...)

Realizarei todos os teus poemas, imaginando como eu seria feliz se [pudesse estar

contigo e ser tua sombra

(PIVA, 1961)

Como vemos, há similaridade quanto ao tom com que Pessoa-Álvaro de Campos se dirigia a seu poeta eleito. Pela veemência da comunhão entre poeta e leitor, há 
identificação que se traduz em cumplicidade. Duas aventuras se contemplam, sendo aquela do passado o combustível para o novo navegante. Poeta-leitor e poeta lido confluem como num jogo de espelhos, ou como Narciso ${ }^{27}$ diante de seus traços na superfície do lago.

Desse modo a leitura é constitutiva de uma cosmovisão marcada por atitude comportamental específica: o ímpeto adolescente embriagado de literatura. Há osmose. E também metamorfose do sujeito que busca viver em sua cotidianidade aquilo que lê. Há, ainda, aquela identificação intensa entre a experiência poética e a marginalidade. Isso não implica somente o ofício do verso - implica uma forma de agir testemunhada pelos poemas.

Em Willer percebemos que o delírio poético é incorporado enquanto forma privilegiada de pensamento: um caminho, portanto, para conhecer e alcançar a realidade. Inclusive, pela memória. Em Piva há algo da mesma natureza, e ainda, na ode acima citada, sua leitura de Pessoa é aliada à do modernismo brasileiro e converte-se em emblema: "Vamos viver para além da burguesia triste que domina meu país alegremente/ Antropófago". De certa forma esta ode anterior a Paranoia, primeiro livro de Piva, prenuncia o sincretismo que será notório na poesia do autor nos anos setenta e oitenta.

Segundo o crítico Davi Arrigucci Jr., Piva "mobiliza o que lê, o que ouve ou vê”, "com a mesma fúria com que investe contra seus fantasmas" (2008, p.189). Parece-nos correto sugerir que tal modo de lidar com a arte (sobretudo da poesia) mais que pura exaltação, remete a uma forma de problematizar as tensões e contradições entre as esferas da vida e da literatura. É evidente o caráter vanguardista do desejo de

\footnotetext{
${ }^{27} \mathrm{Na}$ identificação com seus poetas eleitos Piva vê a si mesmo e por intermédio desse reconhecimento busca burilar sua experiência existencial e poética.
} 
incorporação da arte na práxis vital. Basta observarmos novamente dois trechos do que foi comentado acima.

Em Willer:

o dia em que todos os relógios pararam, todos os espelhos se embaçaram, e nenhum caminho levava a qualquer lugar então imitamos os poetas

Em Piva:

Realizarei todos os teus poemas, imaginando como eu seria feliz se [pudesse estar contigo e ser tua sombra

Mas como imitar os poetas ou realizar seus poemas? Não estaríamos aqui nos arriscando simplesmente a constatar uma espécie de verve quixotesca por parte de Piva e Willer? Em que consistiriam exatamente tais afirmações tendo em foco categorias aparentemente tão contraditórias como a arte e a vida? O que percebemos, de imediato, é que a relação tradicional entre produtor e receptor de arte é pervertida. A contemplação de efeito lenitivo diante das mazelas da vida cotidiana é descartada em tal modo de fruir obras literárias - o que se expressa, na verdade, é forte desejo de ação, no sentido de engendrar experiências autênticas, para além dos ditames do mundo reificado.

Considerando o que foi até aqui apresentado, esta dissertação se propõe a buscar os fundamentos desta concepção radicada sobre a necessidade de incorporação da arte na práxis vital, procurando compreender como o diálogo particular desses poetas com a tradição sugere os parâmetros de uma poética. Assim, no primeiro capítulo, servindonos de noções de críticos como Peter Bürger, Andréas Huyssen, Hal Foster, entre 
outros, analisaremos o ímpeto vanguardista presente em Piva e Willer, verificando os procedimentos que os aproximam de tal referência, conduzindo a uma atualização, transformação e possível permanência do propósito essencial das primeiras vanguardas e dos anos heroicos do surrealismo.

No segundo capítulo, tendo como alicerce de nossa abordagem o elo entre as matrizes teóricas do romantismo e as vanguardas, do modo como é apresentado por Octavio Paz em Os Filhos do Barro (1984), entre outras referências, tentaremos mostrar como essas matrizes seriam evocadas na relação de nossos poetas especificamente com a beat generation e o surrealismo. Trata-se de evidenciar alguns diálogos e influências mostrando a importância dos mesmos.

No terceiro e último capítulo, trataremos da problemática decorrente de uma poética que se afirma por meio da negação da arte descolada da vida. Veremos assim a forma como a questão literária e sua possibilidade de realização influem na suposta intervenção do texto como meio de transformar, conhecer ou incorporar novas percepções. Discutiremos assim o cerne da produção de nossos dois poetas. No decorrer do trabalho nos utilizaremos de poemas escolhidos ao longo de toda a obra de ambos. 


\section{I-SALTIMBANCOS DE UMA NOVA ORDEM DAS COISAS}

\section{I.I - OS QUE VIRAM A CARCAÇA}

Representantes do ponto de ruptura buscado pela Periferia Rebelde, os manifestos assinados coletivamente por Os que viram a carcaça, ${ }^{28}$ foram escritos na íntegra por Piva e expressam em tom satírico o posicionamento do autor, cujos fundamentos são cruciais para seu companheiro de aventuras literárias, Claudio Willer. Ao apostrofar a lógica, a ciência, a ideologia do progresso e o racionalismo, esses panfletos demarcam território e especificam elementos significativos. Desejam atacar a sociedade burguesa em suas bases, as quais entendem como categorias que agem de dentro da cultura. Nesse sentido, o primeiro alvo é a própria constituição do eu enquanto produto de uma estrutura social e ideológica.

Assim, a imagem piviana do vate enfurecido é encarnação ideal do discurso daqueles que "viram a carcaça" e que afirmam seus princípios, localizando-se, antípodas na vida literária de seu país. O poeta e seus amigos ${ }^{29}$ são belicistas, sarcásticos e persuasivos ao avançar com inumeráveis farpas na direção do que consideram a "mensagem lírica do Mimo" das "bordadeiras de poesia", que perpetuam o funcionamento do "torniquete da Consciência" e das "bombas de gás dos funcionários públicos”.

\footnotetext{
${ }^{28}$ Os manifestos em questão, como relata Willer no já citado posfácio ao primeiro volume das obras completas de Piva, datam de março de 1962 e foram distribuídos em cópias de mimeógrafo. Tais manifestos constam nesse Um estrangeiro na legião (2005). Encontram-se também anexados ao final deste trabalho, para que possam ser lidos na íntegra.

${ }^{29}$ Não há informações precisas sobre quem, além de nossos poetas, estava propriamente representado em "Os que viram a carcaça", no entanto deduz-se que provavelmente são aqueles cujos nomes temos citado até agora ao longo deste trabalho, como Roberto Bicelli, Rodrigo de Haro, De Franceschi, a artista plástica Maninha, Décio Bar, Sérgio Lima.
} 
O posicionamento é "contra a vagina pelo ânus" e contra "Eliot pelo Marquês de Sade", contra "a mente pelo corpo" e "contra Hegel por Artaud", "contra Virgílio por Catulo" e "contra a lógica pela Magia", "contra os professores pelos pajés" e "contra o violão pela bateria". Toma-se partido dos "macumbeiros", dos "loucos confidentes", "cafajestes com hemorroidas" e de "todos que detestam os sonhos incolores da poesia das arcadas". Desata-se no púlpito da "Catedral da Desordem" a prédica virulenta em apologia de uma arte da libertação dos instintos, do brilho do inconsciente:

É preciso não ter medo de deixar irromper nossa Alma Fecal. Metodistas, psicólogos, advogados, engenheiros, estudantes, patrões, operários, químicos, cientistas, contra vós deve estar o espírito da juventude. Abaixo a Segurança Pública, quem precisa disso? Somos deliciosamente desorganizados e usualmente nos associamos com a Liberdade.

Voltam-se assim contra uma poesia de "gabinete", descolada do corpo a corpo com as ruas e, por conseguinte, da vida e da complexidade humana e existencial que decorre do aqui e agora. Podemos perceber nesse texto sintético, telegráfico, ${ }^{30}$ que a opção é pela irreverência ("amigos que não sejam sérios"), com ênfase no sincretismo afro-brasileiro ("os macumbeiros”), na loucura avessa às convenções ("os loucos confidentes"), avançando para um sentimento ao mesmo tempo aristocratizante e trágico (“os imperadores desterrados”) que culmina no esgar, na sátira virulenta, sanha suicida que se mostra pelo nonsense de imagens aparentemente gratuitas dentro do texto, como a figura das "freiras surdas" e dos "cafajestes com hemorroidas". ${ }^{31}$ A isso

\footnotetext{
${ }^{30}$ Claudio Willer em seu posfácio ao primeiro volume das obras completas de Piva comenta o caráter conciso desses manifestos, que remeteria, pela "rapidez telegráfica do texto" aos "manifestos dadá de Tristan Tzara, os precedentes manifestos do futurismo de Marinetti, e os subsequentes manifestos da Poesia Pau-Brasil e Antropófago de Oswald de Andrade” (p.149, 150).

${ }^{31}$ A figura das "Freiras surdas" é provavelmente uma alusão ao Pablo Neruda de "Walking around", no qual "Sin embargo sería delicioso/ assustar a um notário com um lirio cortado/ o dar muerte a uma monja com um golpe de oreja." Também neste mesmo poema do autor de "Residencia em la Tierra" há utilização de nonsense em imagens como "ir por las calles com um cuchillo verde/ dando gritos hasta morir de frío" (NERUDA, 1978, p.69).
} 
se segue a ratificação do caráter declaradamente marginal do poeta e de seus amigos por meio do ataque à ordem dos "sonhos incolores da poesia das Arcadas", da "ternura de lacinhos" e das "borboletas douradas". Protesta-se contra a escrita-filigrana do ramerrão burguês - verniz bem pensante sob o qual se esconde o "cintilante conteúdo das latrinas" que é a matéria anímica da rebeldia piviana. É difícil não reconhecer nessas invectivas a referência aos remanescentes da geração de 45 e ao concretismo, movimentos cujos propósitos os nossos poetas entendiam como algo contíguo à ordem estabelecida, correlatos, portanto dessa mesma ordem. É o que nos mostra este trecho do prefácio que Piva escreve para o livro de Willer, Anotações para um apocalipse (1964), tratando tendências diferentes de modo homogêneo, talvez porque nos fundamentos de cada uma haja em comum a predominância da dimensão racional do processo criativo:

Toda poesia oficial brasileira, todo este acervo pernicioso-fútil de neoparnasianos, concretistas, marxistas de salão, rilkeanos lacrimosos representam um desejo insaciável de autoridade, de impotência mística, de resignação artificial \& patológica diante de uma Sociedade patriarcal \& opressora. (p.5)

Podemos perceber o eco daquela ideia professada por Georges Bataille, que associa irremediavelmente a literatura à transgressão ao afirmar que: “A literatura é o essencial ou não é nada. O mal, uma forma penetrante do Mal”, sendo que “(...) esta concepção não impõe a ausência de moral, exige uma hipermoral.” (BATAILLE, 1989, p.9,10). Ora, as ideias de Piva se encontram em harmonia com as do autor de $A$ Literatura e o Mal, justamente no que concerne ao fato de que a criação artística, para ambos, só pode ser entendida como uma forma de fugir ou até de desmantelar os princípios de uma realidade que sufoca o indivíduo. Uma literatura que consente em ser parte da estrutura vigente seria de pronto, menor - para não dizer falsa. Dessa maneira, para Piva e amigos: 
Os pontos cardeais dos nossos elementos são: a traição, a nãocompreensão da utilidade das vidraças, a violência montanha-russa do Totem, o rompimento com os penicos estreitos da Lógica, contra o vosso êxtase açucarado, vós, como os cães sentis necessidade do infinito, nós o curto-circuito, a escuridão e o choque somos contra a mensagem lírica do Mimo (...) nós estamos perfeitamente esquizofrênicos, paranoicamente cientes que devemos nos afastar da Bandeira das Treze Listas cujos representantes são as bordadeiras de poesia que estão espalhadas por toda a cidade.

Como podemos ver: se nesses textos se afeta loucura, é por ódio aos imperativos perversos da ciência. Nesse sentido, remontam-se mesmo os manifestos dos dadaístas do início do século XX. O tom de provocação marcado pelo humor e descompromisso, com espírito alegre e juvenil vomitando descrença ante os olhos da sociedade é uma forte marca de semelhança entre o texto piviano e este de Tristan Tzara:

\begin{abstract}
A ciência diz que somos os servidores da natureza: está tudo certo, façam amor e partam a cabeça. Continuem, meus filhos, humanidade, burgueses amáveis e jornalistas virgens... Sou contra os sistemas, o mais aceitável dos sistemas é o de, por princípio, não ter nenhum. Completar-se, aperfeiçoar-se dentro da pequenez própria até encher o vaso do eu, coragem de combater a favor e contra o pensamento, mistério do pão explosão súbita duma hélice infernal em lírios econômicos (...), (TZARA, 1987, p.16).
\end{abstract}

Trincheira arriscada e ao mesmo tempo sedutora, a atmosfera dadaísta que insiste em negar uma percepção estagnada da cultura, atinge de forma precisa os fundamentos da racionalidade voltada para os fins. Mas algo mais complicado se coloca quando pensamos nas implicações disso diante da estrutura burguesa que a tudo devora indiscriminadamente. O crítico Alcir Pécora (2005, p. 20, 21), refere-se a "Os que viram a Carcaça", ao tratar de um "sistema de oposições manifestamente esquemático" que se observa nos poemas de Roberto Piva, ressaltando que tal esquematismo se presta a esclarecer "sem meias-tintas a situação básica de impedimento e repressão" que o poeta "reconhece como constitutivo do mundo burguês" para, então, "lançar-se abertamente 
ao confronto" (2005, p.11). Cabe a nós salientar, entretanto, que a insistência no binarismo pode incorrer em fraqueza: o poeta e seus amigos correm o risco de fincar raízes ao firmarem os pés em território específico. Assim, uma vez localizados, podem ter suas estratégias cerceadas. Do mesmo modo a loucura da qual se servem com ênfase no prazer do esgar e na satisfação imediata dos instintos pode servir muito bem aos propósitos do capitalismo e da sociedade técnico-industrial que sabe se utilizar largamente desses elementos. Perdem, assim, por polarizarem, considerando que um dos maiores atributos desta posição é a fuga das viseiras ideológicas dos formalismos e dos CPCs. Os que viram e resolveram virar a carcaça da cidade que vai vertiginosamente transformando-se em carniça de concreto pelo processo de industrialização e modernização podem resvalar no desalento de outra viseira: a do malditismo. ${ }^{32}$ Seus posicionamentos são, também, passíveis de captura. Entretanto, esse viés parece ter possibilitado uma visão privilegiada do processo histórico e social na medida em que são buscadas alternativas diversas das determinações estéticas e ideológicas correntes.

É por meio da abordagem argumentativa e expositiva, mas não menos combativa, em tudo imbuída daquele espírito de rebelião das primeiras vanguardas e do surrealismo, que Claudio Willer (também na perspectiva de representar um ponto de ruptura próprio da sua experiência com a Periferia Rebelde) coloca a questão da arte em seu tempo. No manifesto “As fronteiras e dimensões do grito" (1964), após tratar do

\footnotetext{
${ }^{32}$ Piva, entretanto, parece saber desse risco. Como podemos perceber neste trecho da entrevista concedida a Paula Dume e Renata D'Ellia: “Como se sobrevive num mundo em que essas pessoas e instituições mandam? Sobrevive com vaselina no corpo. Você tem que ser escorregadio. E ninguém te pega? Eles pensam que pegam, mas não pegam". "Ebulições pivianas". Disponível em: http://www.cronopios.com.br/site/artigos.asp?id=2739. Também Willer mostra conhecer tais riscos ao dizer, no "posfácio" à Dias circulares, de 1976, que "O marginal tende a sacramentar a boa consciência do burguês, é socialmente necessário. Ele é o reverso da mesma medalha, o oposto dos valores estabelecidos, mas não a sua negação, no sentido hegeliano da palavra. A experiência imediata mostra isso: a tríade bandido-alcaguete-policial é uma coisa só, os papéis são trocados com incrível facilidade" (WILLER, 1976, p.14).
} 
texto "O poeta e as revoluções" de Allen Ginsberg, afirma que o chamado à "ampliação da área da consciência", enunciado pelo poeta maior da geração beat, "coloca a poesia moderna numa derivação direta em relação ao Romantismo”. (1964, p. 36). Sob essa ótica, Willer evoca os poemas proféticos de Blake, os "Fragmentos de Novalis", Hölderlin, o "Goethe alquimista”, Jean Paul Ritcher. Ao nomear tais referências, inserese nessa tradição e identifica-se à condição de vidente que atribui aos poetas citados. Obviamente, serve-se do imperativo de Rimbaud de que "É preciso tornar-se vidente". Expõe dessa forma sua própria vocação:

De Blake a Rimbaud, de Rimbaud a Ginsberg e ao Surrealismo, uma mesma tradição, uma só continuidade, dando origem a uma arte cada vez mais livre, mais premonitória, mais coletiva.

Eis o grande legado de todos esses poetas, de todos esses românticos e contemporâneos, de todos esses seres definitivos: uma visão clara do papel do poeta frente a seu tempo e do contínuo histórico onde se inserem todas as grandes manifestações do século XX, e, acima de tudo, um alto padrão de conduta, de dignidade, de fidelidade a si próprios, à sua missão, ao seu destino, pondo em cheque tranquilidade, bem estar, equilíbrio psíquico, em suma toda sua vida, no empreender dessa aventura espiritual (idem)

Diferente de Piva, o manifesto willeriano se utiliza da argumentação, da tentativa de, por meio do discurso, combater no campo das ideias. São frases que apresentam proposições definidas que, mesmo incandescentes, apaixonadas, buscam abordar e subjugar uma visão de mundo pautada pelo conformismo. Tal concepção arrebatada evidencia o deslocamento desses poetas em um panorama cujo debate cultural ocupavase entre os polos do formalismo e da militância; restrito, portanto, às linhas de força que pareceram mais apropriadas aos setores informados da sociedade brasileira. Deu-se nessa perspectiva a resposta histórica da poesia concreta e do praxismo, assim como aquela da produção cultural associada ao CPC. O chamado à tomada de consciência e à rebelião individual do modo como Willer postula só figuraria como algo mais coerente 
quando começaram a se tornar correntes no Brasil certas percepções advindas da contracultura.

Sob o fenômeno que Roberto Schwarz (1978) chama de relativa hegemonia cultural da esquerda durante os anos da ditadura militar, os manifestos em questão praticamente não repercutiram, mesmo que, como vimos nos trechos acima comentados, procurassem dialogar e se posicionar diante do momento. As provocações de acentuado nonsense, tais quais vimos em "Os que viram a carcaça" e o derramamento de subjetividade rebelde e inconformada de "As fronteiras e dimensões do grito" talvez pudessem oferecer ao leitor da época somente a fantasmagoria de um horizonte estilhaçado. À maneira do louco piviano que cola pedacinhos de céu na camisa de força, essa postura política e existencial intenta uma transmutação de valores ${ }^{33}$ e um choque com a sociedade avesso a qualquer formulação além do aqui e agora. Piva e Willer comprazem-se nisso ao tornar essa perspectiva uma mística da qual tiram seus lampejos de lucidez, de criatividade e originalidade: ao mesmo tempo a cisão com o mundo parece querer resolver-se buscando incessantemente uma comunicação, um aliciamento, chamar e convencer o outro para a necessidade utópica de criar novas formas de existência. Como sentiria a linguagem os efeitos de tal empresa?

I-III - A PERFEITA MÚSICA ESTÁ NO AÇO (CONSIDERAÇÕES BREVES)

Um procedimento fundamental da obra de arte vanguardista como o conceito de montagem inferido por Peter Bürger em sua Teoria da vanguarda (2008) encontra-se

\footnotetext{
${ }^{33}$ No texto de Maria Rita Khel acima mencionado, a crítica compara a expressão nietzschiana do "filosofar com o martelo" com a concepção artística de Piva. Afirma, dessa maneira, que o poeta, leitor de Nietzsche, se empenhava em criar uma "poesia a marteladas".
} 
em nossos poetas no sentido de uma participação histórica efetiva, a partir do mergulho na própria individualidade enquanto parcela constitutiva de uma experiência maior. Implica compromisso com aspectos da vanguarda no sentido, não de repetir movimentos contestatórios cuja estridência já se encontra esvaziada de significado, por ter sua ferocidade dissipada no horizonte da História, mas de entender melhor o modo como se constituem as práticas discursivas em um mundo tomado pelos ditames da tecnocracia, sugerindo possibilidades de desmoronar essas mesmas práticas.

Nessa perspectiva, é interessante atentar para o conceito de obra não orgânica que Bürger depreende da arte vanguardista. Semelhante obra deixaria transparecer a ação mesma da produção, ou a subjetividade do produtor, prescindindo da inteireza de uma imagem do mundo que se ofereça como reconciliação entre o homem e a natureza. A montagem, como princípio composicional desse tipo de produto artístico, mantém o status artificial, mostra um arranjo de fragmentos em que as descontinuidades, tensões e impossibilidade de síntese figuram como uma infinidade de relações entre as partes individuais e o todo, sendo que cada parte pode ser apreendida em separado. Feita de ruínas, a criação inorgânica engendra, na sua aparente ausência de sentido, o desafio para se buscar outro tipo de sentido, fora das relações conhecidas pela racionalidade. Assim, a relação que se estabelece com o expectador, não pode, de modo algum, ser passiva - ela o instiga: a subjetividade receptora passa a participar ativamente do processo criativo.

Podemos encontrar princípio análogo em Piva. Notemos que, no poema apresentado abaixo, cada bloco imagético que poderíamos compreender como um só verso de fôlego longo resultaria por si só num poema individual, pela hipótese de que apresenta uma realidade que não tem necessariamente que se encadear com a seguinte 
para ser validada. No entanto a relação entre os blocos gera uma sucessão de imagens justapostas que fustiga o leitor que, mal acabando de assimilar uma figura complexa e multifacetada já é lançado em outra da mesma natureza e, geralmente, com a mesma intensidade:

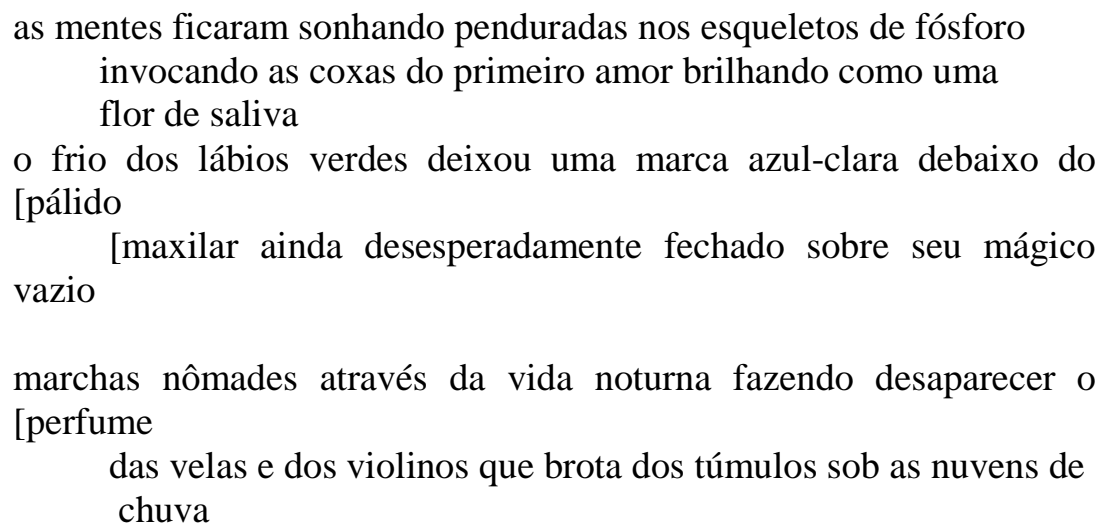

(“Visão 1961”, Paranoia, 1963)

O eu lírico capta takes da noite urbana, transfigurados pela imaginação. A composição imagética se fixa, nesse sentido, em certa narratividade que tem o primeiro efeito de atirar ao leitor, de modo abrupto, uma realidade onde tudo é de outra ordem, a saber, a ordem do sonho e do delírio cuja única lei possível é a da analogia, onde tudo tem a ver com tudo e uma coisa, sendo o que é, também é outra, sem perder suas propriedades. Assim, há corpos, mentes e objetos sobrepostos e em perspectivas alteradas. Dançando desvairadamente como ruínas em uma tempestade. Tudo excessivo, pois o sujeito configurado pela dilatação de seu sopro lírico deseja abarcar multidões. A falta de pontuação associada à ênfase nos verbos promove uma imagem duplicada, ou prismática, que torna os planos simultâneos: são as mentes que "ficaram sonhando" que invocaram "as coxas do primeiro amor" ou os "esqueletos de fósforo" sobre os quais elas estavam penduradas? São as "mentes" ou as "coxas" que estão "brilhando como uma flor de saliva"? Grava-se assim uma percepção múltipla, caótica. 
Em Willer percebemos algo da mesma natureza. Nesse caso, o movimento aleatório, calcado nas categorias do acaso dado à disponibilidade do sujeito, cede gradativamente à ânsia da montagem como possibilidade de compor imagens. O artifício se expõe entregando ao leitor a própria matéria do poema. Crua, sem qualquer relação lógica, movida apenas pelas relações intermináveis que se inferem de um encadeamento de associações livres:

\begin{abstract}
A palavra Amor desaba pelas paredes do quarto, com um turbilhão de outras palavras: cratera, aventura e fonte, navio, acaso e fuga, serpente, hora e salamandra, astro, circuncisão e potência, batismo de chamas, lâmpada submersa e gavião metálico, sombra calcinada, ossos enferrujados e areias movediças, tocaia de insetos ardentes, febre de sensações líquidas e marfim cravado de flechas, espirais de concreto colorido, locomotivas embriagadas ao poente e associações de leopardos tristes, cânticos soprados pela estepe, cortinas rasgadas dançando ao meio-dia, mantos hipnotizados, obscuridade povoada de plantas aquáticas, ilha habitada por morcegos, florestas de arbustos congelados, tempestade de pombas atravessadas por agulhas, antemanhãs, libélulas.

(“O vértice do Pântano”, Anotações para um apocalipse, 1964).
\end{abstract}

Cada palavra no poema em prosa passa a ter, ela mesma, pela sua própria carga semântica, relevância simbólica descolada do todo - e é justamente este aspecto que a composição procura destacar. A combinação entre uma e outra palavra vai gerando o efeito de surpresa (embora estejam sendo levadas pela mesma cadeia semântica) à medida que pede por mais combinações que se desdobram - a ambientação do poema se dá pela natureza altissonante das invocações: há um aspecto trágico, de magnitude ao mesmo tempo afirmativa e autodestrutiva, pois toda experiência sugerida ao longo do monólogo de forte musicalidade é definitiva e única. Sob essa ótica o ritmo que se impõe é o da conjuração mística, do palavreado do mago, bruxo ou feiticeiro. A realidade se desintegra, captada como sucessão de linguagem em lascas. São palavras soltas que o eu lírico persegue parecendo querer se integrar a uma noção de vida 
cósmica. Apresenta assim uma percepção ligada a concepções arcaicas de existência, sugeridas pela alusão a rituais sagrados e a figuras mitológicas como a salamandra, ao mesmo tempo associada à vida natural.

O processo enumerativo remonta àquele do poeta norte americano Walt Whitman tal como apresentado por Leo Spitzer em Lingüistica e Historia Literaria (1968). O lirismo whitmaniano se utilizaria, segundo o crítico, de artifício comparável àquele dos versículos bíblicos que, no intuito de nomear a Deus, listam uma extensa gama de nomes; o que implica uma tentativa de abarcar a totalidade divina. Mas, ao adaptar esse procedimento enumerativo para referir-se à vida na grande cidade, o que era totalizante na Bíblia e nas antífonas medievais, torna-se, segundo o autor, "caótico", pois se perdeu, na modernidade, a noção de sagrado e de totalidade característicos da linguagem religiosa tradicional. Willer se utiliza desse método de forma parecida, desdobrando a partir do vocábulo "Amor" uma série de conjurações que, enfim, termina por criar vasta teia de palavras-fragmento.

Temos assim uma valorização do lúdico e do acaso na criação poética. De forma diferente essas categorias contribuem para gerar uma voz original em cada um de nossos poetas. Faz-se notória uma busca pessoal que se configura ao mesmo tempo como expressão genuinamente artística e manifesto desprezo pela arte. Nesse sentido, a fala ininterrupta que se vê em Piva, ou o vezo verbal em fluxo associativo mostrado em Willer têm a qualidade de figurar como "orgia" entre o sujeito (eu liquefeito) e a palavra (rio dos signos com feições de universo). Esse trato resulta em uma escrita composta por imagens na qual se destaca a intensa sonoridade. A materialidade do verbo pode ser sentida em meio ao caos que se promulga numa desorientação constante das perspectivas e do olhar: 
UM Sonho aSSírio, eiS noSSa diMenSão. Um crânio aMargo, velejando com a incon $S$ tân $C$ ia do $S \operatorname{arcaSM} \boldsymbol{M}$ e $\boldsymbol{M} \boldsymbol{M}$ eio a emboScada $\boldsymbol{S}$ de inSetoS, um crânio azul e $\boldsymbol{S u l c a d o}$, à janela nos $\boldsymbol{M o} \boldsymbol{M}$ ento $\boldsymbol{S}$ de eSpera, um crânio negro e fixo, $S$ eparado da $\boldsymbol{M}$ ão $\boldsymbol{S}$ que o a $\boldsymbol{M}$ para $\boldsymbol{M}$ por tubo $\boldsymbol{S}$ e e $\boldsymbol{S M}$ agando os brônquio $\boldsymbol{S}$ da $\boldsymbol{M}$ eMória.

(“Anotações para um apocalipse" Anotações para um apocalipse, 1964).

A forte presença das aliterações, tais como as destacadas em $\boldsymbol{S}$ e $\boldsymbol{M}$, junto à imagética cerrada, mostra uma tensão para com a estrutura do texto - frases com início, meio e fim, cujo ritmo, sempre desdobrando em outra perspectiva a imagem anteriormente apresentada - que parece, pela pseudo-explicação de um texto em prosa altamente discursivo, funcionar como uma espécie de paródia da prosa científica - uma intenção filosófica (mas baseada no pensamento analógico, manifesto em imagens) de perverter a razão, sem, no entanto, abandoná-la. Apesar de sua estrutura, não se trata de um discurso orgânico. Só é possível extrair sentido dessa composição se renunciarmos a certas relações lógicas calcadas em nossa percepção cotidiana.

Piva, cujo apreço pelo caos poético mostra-se na percepção múltipla e no olhar desagregador que ostenta, utiliza-se frequentemente da sequência enumerativa, prescindindo da pontuação, gerando um fluxo contínuo em que as imagens se aglutinam:

relógios podres turbinas invisíveis burocracias de cinza cérebros blindados alambiques cegos e viadutos demoníacos capitais fora do Tempo e Espaço e uma Sociedade Anônima regendo a ilusão da perfeita bondade

(“O Volume do Grito”, Paranoia, 1963)

O risco de "massa informe" pode encontrar, contudo, nesse caos advindo dos movimentos da subjetividade, uma forte marcação sonora, uma clara consciência rítmica, como no poema abaixo, do livro Piazzas: 


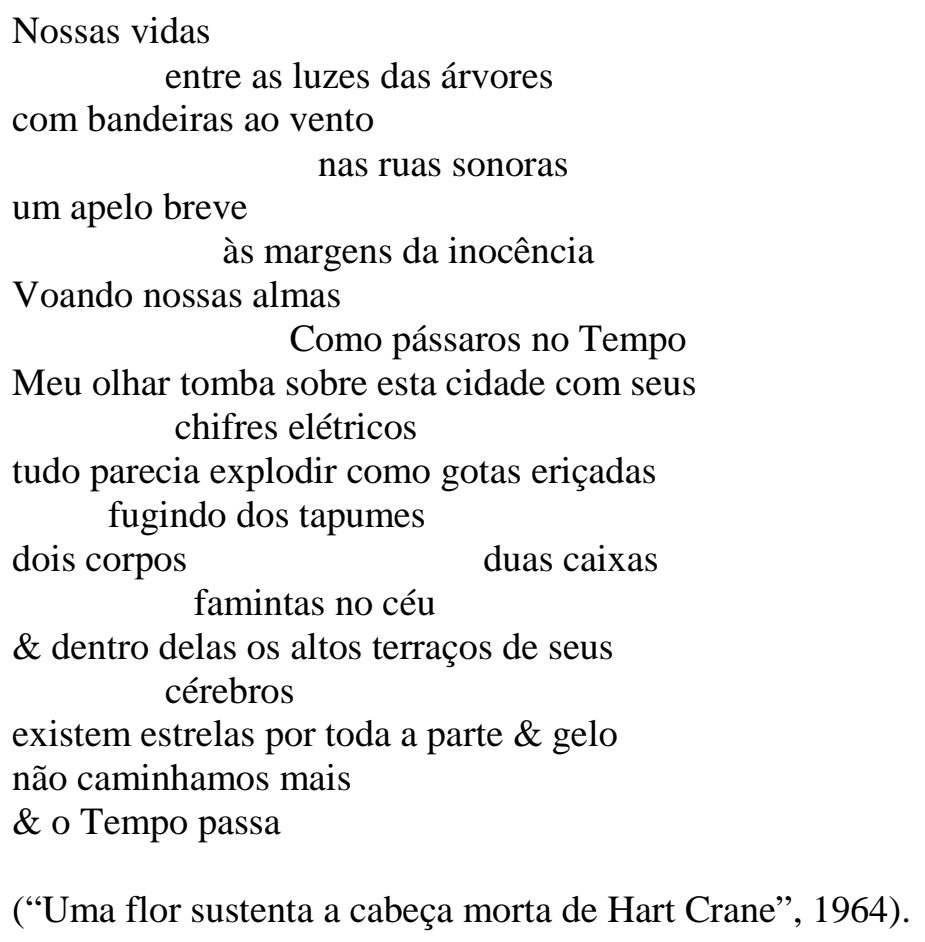

Vemos que o jogo de versos sobre o espaço da página (à maneira da marcação sonora bastante utilizada pelo poeta russo Maiakovski) obedece à pulsação lírica do sujeito, varia de acordo com seus movimentos interiores (é suave até “como pássaros no Tempo", mais pesada e conflituosa após a referência aos "chifres elétricos" da cidade e volta ao tom inicial, numa espécie de circularidade que podemos ver nos últimos três versos). A construção, no entanto, é sempre fugidia no sentido de que o que a conduz são elementos de prazer, do lúdico êxtase da escrita alheio a pretensões realistas, como neste fragmento em prosa:

Os eixos na imensa vibração exaltam a tinta da folhagem seca na esfera dos trombones marinhos um pouco à minha disposição em brilhos de Tômbola. Espinheiros de carga elétrica nos túneis de ovos fritos. O barco levará certamente a tripulação de protozoários \& bandeiras.

(“Heliogábalo", Piazzas, 1964)

Procura-se romper com as relações de causa-efeito. As sequências se quebram. Mergulhado no caos da linguagem o sujeito busca capturar algo - o próprio eu, um eu 
mais verdadeiro, fazendo com que a crosta de convenções possa ruir? A desagregação do sujeito é, nesse sentido, o ponto de que parte o artista. A conquista das categorias de ruptura até então mencionadas, se daria, sob essa ótica, a partir da conquista ou do engendramento de uma subjetividade singular. Numa criação fundada sobre a necessidade de fazer ruir o ramerrão da existência (alicerçado pela razão despótica), a responsabilidade diante da linguagem implicaria a coragem do poeta ao administrar em seu texto toda a visceralidade de sua vivência. Mas, para observar tais questões e reconhecermos a autenticidade dessa empresa teríamos de recair no biografismo? Ao menos teríamos de enfrentar a problemática própria da relação, um tanto delicada, entre poesia e vida que conduz às feições da subjetividade romântica.

Nesse sentido, Susan Sontag em seu ensaio sobre Antonin Artaud mostra-nos uma abordagem distinta que espanta o fantasma lacrimoso do poeta ingênuo e confessional a que nos remete a certa concepção do romantismo. Ao atualizar essa concepção na modernidade, a autora a define como uma escrita em que "uma personalidade singular se expõe heroicamente". Dessa forma:

Na visão deflagrada pela sensibilidade romântica, o que é produzido pelo artista (ou pelo filósofo) contém, como estrutura interna reguladora, uma descrição dos trabalhos da subjetividade. A obra deriva suas credenciais do seu lugar numa determinada experiência vivida; assume uma totalidade pessoal inexaurível, da qual "a obra" é um subproduto, derivado e inadequadamente expressivo daquela totalidade. A arte torna-se uma afirmação da autoconsciência — uma autoconsciência que pressupõe uma desarmonia entre a pessoa do artista e a comunidade. De fato, o esforço do artista é medido pelo tamanho de sua ruptura com a voz coletiva (da "razão"). O artista é uma consciência tentando ser. "Eu sou aquele que, para ser, deve fustigar o que me é inato", escreve Artaud - o mais didático e mais intransigente herói da auto-exacerbação na literatura moderna. (SONTAG, 1980, p.17).

A questão seria, sob esse viés, criar uma obra visceral, no sentido de gerar a partir do ponto discordante do eu, uma obra que ilumine, ela mesma, a própria vida. 
Que incendeie seus interditos para que se adentre numa floresta de desvendamentos (a arte é um instrumento de revelação com que o eu escava a possível originalidade de sua existência). Embora a aventura de Piva e Willer não tenha o acento trágico de Artaud, é impossível deixar de notar em seus respectivos discursos programáticos, assim como nas suas produções poéticas propriamente ditas, os ecos do criador do Teatro da Crueldade:

Lá onde outros propõem suas obras, eu não pretendo fazer outra coisa senão mostrar meu espírito.

A vida é de queimar as questões.

Eu não concebo nenhuma obra separada da vida.

Eu não gosto da criação separada. Eu não concebo tampouco o espírito como separado de si próprio. Cada uma de minhas obras, cada um dos planos de mim mesmo, cada uma das florações glaciais de minha alma interior baba sobre mim. (ARTAUD, "No Umbigo dos Limbos", 1970, p.207).

Vemo-nos assim, inevitavelmente, diante da figura romântica do artista. Após tratarmos da problemática em torno das vanguardas (que pagaria tributo a tal figura) procuraremos, no capítulo que segue, explicitar o modo como essa questão aparece especificamente nas poéticas de Piva e Willer.

I-III - ESTREPOLIAS DA VANGUARDA

No livro Teoria da vanguarda, (2008) o crítico alemão Peter Bürger, detém-se, entre outras questões, no suposto fracasso das vanguardas históricas. Esse fracasso seria assinalado pela impossibilidade do intento de reconduzir a arte à prática da vida cotidiana de modo a romper com a racionalidade voltada para os fins, característica da sociedade burguesa. Nesse sentido os vanguardistas, ao colocarem em xeque o status de 
autonomia e, consequentemente, a instituição arte, acabaram por redefini-la. Assim, vemos que criaram novas possibilidades para a existência da obra de arte autônoma, alargaram o território da criação artística e tiveram, com o desdobramento desse processo, sua rebelião transformada, muitas vezes, em convenção, sua força provocativa institucionalizada. $^{34}$

Segundo Bürger, as "neovanguardas", ao proclamarem em certa medida os mesmos objetivos das vanguardas históricas, fariam algo oposto às intenções de explodir a instituição arte da forma tencionada por manifestações como os ready made de Marcel Duchamp. Tendo se tornado receptível o protesto, ele não teria autenticidade, seu ímpeto primeiro seria irresgatável, justamente pelo fato de que a provocação teria sido assimilada institucionalmente, não sendo mais possível pensar em superar a arte na práxis vital. No âmbito dessa possibilidade o que vemos é uma falsa superação dada pela estética da mercadoria, pela capacidade do capitalismo de cooptar muitos preceitos e técnicas vanguardistas para seduzir e subjugar ainda mais o sujeito em sua vida reificada.

Diante do problema apresentado, consideramos que o esforço colocado nos poemas de Willer e Piva (tendo em vista as particularidades da escrita de cada um destes autores) é de uma incorporação ou intensificação da arte na práxis vital bem afim ao propósito acima exposto. Corroborando essa afirmação, Willer em 1964 evoca as vanguardas históricas e Lautréamont como representativos de processos que estão ocorrendo em sua época - elementos decisivos para atitudes a serem tomadas nas circunstâncias históricas diante das quais se vê: o Brasil recém-tomado pelo golpe militar de 1964, marcado por categorias moralistas e retrógradas. A referência ao famoso dito lautreamontiano sinaliza o ímpeto para a poesia em vida:

\footnotetext{
${ }^{34}$ Cf. "O ocaso da vanguarda", capítulo final de Os Filhos do Barro (1984), de Octavio Paz;
} 
Talvez o fenômeno decisivo do século XX seja o fato de percepções e tomadas de consciência até então patrimônio exclusivo de indivíduos isolados estarem tomando cada vez mais um caráter grupal e coletivo, como que obedecendo ao lema de Lautréamont: "A poesia deve ser feita por todos", constituindo um processo histórico do qual Dadá e o Surrealismo são momentos decisivos. (1964, p.51)

Vê-se que o poeta acredita estar diante de um contínuo histórico em que a arte estaria cada vez mais próxima da práxis vital. Nesse sentido, dadá e surrealismo não são manifestações do passado e sim "momentos decisivos" de algo que está acontecendo. Assim, concepção parecida é colocada por Piva, de modo enfático, no já mencionado posfácio-manifesto de seu livro Piazzas, quando postula que "Sob o império ardente do Princípio do Prazer, o homem, tal como na Grécia dionisíaca, deixará de ser artista para ser Obra de Arte" (p.131). O fato é que a problemática posta diz respeito diretamente a questionamentos e conflitos políticos vividos por jovens em todo o mundo de então. Manifestações como a Internacional Situacionista, os Angry Young Men britânicos, a leva de jovens existencialistas da época, o Students for a Democratic Society nos Estados Unidos, mais as new lefts e tudo que decorreu da geração beat se alargando até contracultura está em íntima sintonia com o que Willer e Piva dizem nessa mesma época.

A liberdade imaginativa tem, dessa forma, o caráter de plataforma política, anárquica e coletiva. Diante da suposta verdade histórica do "fracasso" das vanguardas, o que se enxerga no horizonte é o inegável poder de manifestação crítica que implica a projeção das ideias vanguardistas, sua interpretação, reescrita, releitura. É a incandescência iconoclasta alusiva a tais ideias que se vê no modo como Piva e Willer concebem suas poéticas. Não prescindem, paradoxalmente, da poesia enquanto linguagem artística, o que assinala um apreço pela autonomia de seu meio de expressão. 
Seria correto classificar tal empreendimento como neovanguardista? Indubitavelmente Piva e Willer identificam-se com aqueles entusiastas do início (e até meados) do século $\mathrm{XX}$ e neles se inspiram. Mas não haveria no prefixo de que a categoria em foco se serve uma espécie de preconceito? Como se aqueles que nos anos sessenta e setenta invocaram em sua produção manifestações como o expressionismo, o futurismo russo, o surrealismo e afins, fizessem irremediavelmente algo datado? Peter Bürger conclui que o anseio de transpor a arte para a práxis vital da forma como pretendiam os primeiros representantes da vanguarda não tem fundamento enquanto atitude histórica legítima a ser representada em tempos mais recentes: há, porém, diversos modos de se evocar o ímpeto dos primeiros vanguardistas. É o próprio Bürger que afirma ser graças ao empreendimento destes artistas que se torna possível pensar na livre produção de todos. Por meio dos questionamentos que deixaram e das possibilidades que abriram, proporcionaram território para a coexistência de diversas concepções e uma maior liberdade criativa e crítica. O caráter enigmático das obras de vanguarda permanece: questões abertas por um exercício como o da escrita automática se estendem para além dos próprios surrealistas que a lançaram.

No texto intitulado "Em busca da tradição" (1983) Andréas Huyssen discute alguns pontos de fundamental importância no resgate das vanguardas históricas por movimentos de resistência dos anos 70, as quais, como já observamos, abriram espaço para a manifestação da diferença, de outras perspectivas da experiência do sujeito. A pesquisa de culturas fundamentadas em valores distintos daqueles que regem a sociedade burguesa do ocidente é um fator decisivo da herança vanguardista para um movimento como a contracultura. ${ }^{35}$ É notória nos cartazes e manifestações de maio de

\footnotetext{
${ }^{35}$ Essas referências são de nossa parte. O texto de Huyssen não significa endosso dos movimentos que mencionamos.
} 
68 na França, a forte inspiração surrealista. Há ligações entre as ideias do controverso Guy Debord, mentor da Internacional Situacionista e aquelas do grupo de André Breton. A "deriva" dos situacionistas é um desdobramento das deambulações surrealistas, as quais também influenciaram profundamente a redefinição afetiva da experiência urbana tencionada por Debord e seus companheiros. No texto aqui mencionado, Huyssen destaca a necessidade de buscar a tradição nas mais variadas perspectivas, inclusive, considerando as vanguardas como uma das várias tradições disponíveis para compreender a alteridade e o fundamentalmente diverso como marca do tempo presente. Parece ser nesse sentido que Bürger reivindica, em resposta à condenação das vanguardas por parte de Jürgen Habermas, ${ }^{36}$ a necessidade de uma "compreensão dialética das rupturas", pois "é preciso impedir que essa importante categoria se torne um trunfo das teorias neoconservadoras" (1983, p.92). Assim, mostra-se a necessidade de colocar sobrepostas arte e vida, para que, da tensão e da problemática proveniente desta relação possa surgir uma fagulha capaz de proporcionar o desvelamento das categorias da vida reificada cujo alicerce encontra-se na racionalidade voltada para os fins: trata-se de evidenciar frestas existenciais possíveis diante de ideias absolutas e unidimensionais (como aquelas referentes ao Bem, ao Trabalho, à Ciência, à Objetividade, Deus, Pátria e Família) disseminadas por uma linguagem convencional.

Num viés semelhante Hal Foster em The Return of The Real (FOSTER, 1996) contesta a interpretação que Bürger faz das neovanguardas, apresentando-nos a ideia de superação da arte na vida como um enunciado retórico, mas repleto de capacidade crítica em relação ao real. Na verdade, de acordo com o autor, o que os vanguardistas queriam não era necessariamente dissolver a arte na práxis vital e sim manter o estado

\footnotetext{
${ }^{36}$ Em suas críticas às neovanguardas, Bürger segue a ideia de Habermas apresentada no texto"Modernidade versus Pós-modernidade" (HABERMAS, 1983).
} 
de tensão entre as duas esferas. Assim, algumas das chamadas neovanguardas retomariam o sentido crítico deste intuito aspirando problematizar tanto as convenções artísticas quanto as condições históricas diante das quais se encontravam.

É justamente nessa perspectiva que consideramos ocorrer a retomada desse espírito, principalmente no que concerne ao surrealismo, por parte de Piva e Willer. Embora o imperativo vital seja frequentemente postulado em detrimento da arte autônoma, ressaltamos que não se sustentaria, no caso de nossos poetas, o ímpeto de negar a instituição arte. Nem de negar o passado. Porém o aspecto tensional (no sentido de acentuar as contradições) entre as duas esferas, com tudo que daí decorre em termos de contestação, é imprescindível para compreendê-los. Assim, Piva e Willer contradizem-se nos momentos em que pretendem diminuir em suas obras o valor atribuído à produção artística por meio de um vitalismo exacerbado. ${ }^{37} \mathrm{O}$ que percebemos é que essa atitude insere-se em uma tradição na qual vida e literatura se relacionam num conflito constante, e que se inscreve numa postura crítica cuja natureza irracionalista tem como alvo a sociedade técnico-industrial e todo o aparato especializante e desvitalizante que a ela subjaz.

\footnotetext{
${ }^{37}$ Maria Rita Khel, no depoimento publicado no jornal Estadão citado anteriormente, relata o desfecho da entrevista que fez com o poeta e Renato Pompeu no programa Radar Cultural da Rádio Cultura, da seguinte forma: "Renato, o 'verdadeiro' louco, relatou sua experiência manicomial com muita sobriedade e resistiu à sedução do Piva, que tentou o tempo todo levá-lo para seu campo, do elogio à loucura. Ao fechar o programa, Renato reafirmou que a verdadeira experiência da loucura não é nada produtiva. ' $E u$ só escrevo quando não estou louco.' Piva arriscou então um gran finale ao vivo, na lata: 'Pois eu prefiro enlouquecer que escrever. Só escrevo quando não estou na orgia bebendo, me drogando, transando, pirando...'.
} 


\section{II - O ANTIGO CLAMOR DOS PIRATAS TRUCIDADOS}

Desde a época de formação de nossos autores (a importante participação na Periferia Rebelde do grupo dos Novíssimos) passando pelo período da ditadura militar (em que praticamente não publicaram) até trazerem a lume livros fundamentais para suas obras na década de oitenta e sua mais ampla leitura e recepção nos anos mais recentes, notamos que há um olhar seletivo, uma forte afinidade com uma linhagem específica da poesia.

Em ensaio publicado na revista eletrônica Agulha, Lucila Nogueira comenta a relação de Willer com alguns de seus possíveis antecedentes, ligando-o a expoentes do romantismo e simbolismo. ${ }^{38}$ Mostra assim a ligação de nosso poeta com autores como Gerárd de Nerval, Poe, Baudelaire, Rimbaud e, obviamente, Lautréamont. Ao falar sobre o alto índice de referências literárias em Piva, o crítico Alcir Pécora, no prefácio ao primeiro volume das obras completas do autor, fala em uma "linhagem maldita do romantismo" (2005, p. 14) que seria predominante na frequente intertextualidade de sua poesia.

Sendo o romantismo um movimento com manifestações diferentes em contextos variados, talvez possamos especificar qual é a "linhagem maldita do romantismo" de que fala o crítico. Como se daria a relação de Piva e Willer com um movimento tão amplo? Cabe-nos perguntar: ao que, necessariamente, deveríamos nos referir?

\footnotetext{
${ }^{38}$ Disponível em: http://www.revista.agulha.nom.br/ag43willer.htm.
} 
No livro Revolta e Melancolia (1995) de Michel Löwy e Robert Sayre, é colocada a questão da complexidade do "enigma romântico", o que denunciaria a existência de vários romantismos. Diante do problema, perguntam-se:

O que é romantismo? Enigma aparentemente indecifrável, o fato romântico parece desafiar a análise, não só porque sua diversidade superabundante resiste às tentativas de redução a um denominador comum, mas também e sobretudo por seu caráter fabulosamente contraditório, sua natureza de coincidentia oppositorum: simultânea (ou alternadamente) revolucionário e contra-revolucionário, individualista e comunitário, cosmopolita e nacionalista, realista e fantástico, retrógrado e utopista, revoltado e melancólico, democrático e aristocrático, ativista e contemplativo, republicano e monarquista, vermelho e branco, místico e sensual. (LÖWY, 1995, p. 09)

Os autores concebem este enigma como uma "crítica da modernidade", da "civilização capitalista moderna em nome de valores e ideais do passado pré-capitalista, pré-moderno". (1995, p.34) Octavio Paz, em Os Filhos do Barro (1984), também procura definir o contraditório movimento. Deixa assim que sobrevenha de modo mais evidente um ponto de vista filosófico e uma atitude compartilhada por inúmeros poetas da modernidade:

O romantismo foi um movimento literário, mas também foi uma moral, uma erótica e uma política, se não foi uma religião, foi algo mais que uma estética e uma filosofia: um modo de pensar, sentir, enamorar-se, combater, viajar. Um modo de viver e um modo de morrer (PAZ, 1984, p. 83).

O autor especifica, ainda, o que provavelmente tenha sido o ideal supremo dos poetas românticos. Refere-se, para tanto, a um dos fragmentos do expoente do romantismo alemão, o qual ostenta a matriz teórica mais substancial do movimento:

Friedrich Von Schlegel afirmou, em um de seus escritos programáticos, que o romantismo não só se propunha à dissolução e à mistura dos gêneros literários e das ideias de beleza como, através da ação contraditória, porém convergente, da imaginação e da ironia, buscava a fusão entre a vida e a poesia (PAZ, 1984, p.83). 
Diante dos preparativos para a comemoração, pelo governo francês, do centenário do romantismo, André Breton, no segundo manifesto do surrealismo, ressalta que “(...) para ele, cem anos de existência equivalem à juventude (...)”. Declara, desse modo, que o surrealismo seria deliberadamente uma continuação do romantismo; endossa, ainda, o caráter transgressivo que a ele atribui, ao negar as comemorações feitas pelo governo e ao afirmar que a chamada época heroica do romantismo: “(...) já não pode ser honestamente considerada mais que o vagido de um ser que mal começou, por nosso intermédio, a dar a conhecer seu desejo (...)” (2001, p. 184).

Paz partilha de uma visão semelhante à do autor dos manifestos surrealistas. Procura, com ênfase no conjunto de ideias, na insurreição criativa e na poética fundamentalmente analógica, identificar o que seria o verdadeiro romantismo. Revisa, dessa forma, a história da literatura francesa:

(...) o verdadeiro romantismo francês. Existem dois: um, o dos manuais de história da literatura, é composto de uma série de obras eloqüentes, sentimentais, discursivas, que ilustram os nomes de Musset e Lamartine; outro, para mim o verdadeiro, é formado por um número muito reduzido de obras e de autores: Nerval, Nodier, o Hugo do período final e os chamados pequenos românticos. Na realidade, os verdadeiros herdeiros do romantismo alemão e inglês são os poetas posteriores aos românticos oficiais, de Baudelaire aos simbolistas. (PAZ, 1984, p. 92)

Essa perspectiva ressalta o caráter crítico e criativo do fenômeno romântico enquanto manifestação que resistiria à tentativa de circunscrevê-la em um único período determinado. Para Paz, chamar a poesia francesa da segunda metade do século XIX de simbolista seria mutilá-la, pois essas obras prolongariam, traduziriam, seriam metáfora do romantismo alemão e inglês. Uma metáfora na qual o mesmo se contempla, se interroga e se transcende. Poetas como Baudelaire e Rimbaud proporcionariam outra 
versão do romantismo, que essencialmente, seria a mesma, pois a história da poesia moderna para o poeta-crítico é uma confirmação do espírito analógico, o qual, impossibilitado de restituir a unidade perdida, é cindido pela ironia.

Como vemos, Paz descortina uma conexão entre o romantismo e a poesia moderna ao identificar o ímpeto romântico das vanguardas. Seria, dessa forma, possível estabelecer relações de afinidade entre os primeiros românticos e poetas rebeldes da modernidade, poetas que, mesmo em contextos e concepções artísticas diversas, negaram o estado de coisas do presente, encarnaram uma espécie de contradiscurso em seu tempo. É possível identificar esse gesto em autores como William Blake, Novalis, Nerval, Baudelaire, Rimbaud, Lautréamont, Artaud, os surrealistas e a beat generation.

Tais artistas foram malditos, rebeldes, pois, como personagens românticos, encenaram o conflito entre o indivíduo e a sociedade. Confundiram o imaginário e o real. Dessa relação agônica, extraíram sua condição de visionários. Talvez isso tenha sido capaz de conceder-lhes uma perspectiva privilegiada do processo histórico, uma apurada percepção frente aos furos e superfícies escorregadias de seu tempo. Desse modo, como afirma o pensador Isaiah Berlin, os empreendimentos imaginativos dos românticos "não são voos inocentes da fantasia, mas nascem de uma imaginação perturbada em que a vontade não tem controle e o mundo real se revela como uma fantasmagoria" (2002, p.581).

No livro Geração Beat, Willer esboça o modo como o escritor visionário concebe o jogo entre a imaginação e a realidade. Embora não se refira à própria poesia, lança alguma luz sobre sua produção:

Onde o escritor realista supõe a distinção entre dois mundos, o da realidade e aquele da literatura que, mimeticamente, a descreveria, e o escritor formalista não vê interesse em examinar relações entre o mundo autônomo dos signos e a vida, o escritor visionário confunde os dois planos (WILLER, 2009, p.52). 
O movimento beat deflagrado nos EUA após a segunda guerra mundial, cujos representantes mais célebres são os anteriormente citados Allen Ginsberg, Jack Kerouac e William Burroughs, evoca, a seu modo, certa herança romântica conectada com o espírito crítico das vanguardas; busca ainda inovar essa herança no diálogo com representações da cultura norte-americana e da cultura popular em geral como o jazz, que buscam transpor em um complexo trabalho com a prosódia; adicionando a esses elementos a mimetização de uma intensa liberdade vocabular.

Os beats sistematizaram progressivamente em seus poemas o conhecimento e prática de religiões como o budismo, e orientalismos afins. Empenharam-se em buscar novas percepções estéticas, sensoriais e também novas categorias de pensamento. Dessa maneira desenvolveram uma política a partir da arte, na tentativa de mudar a vida por meio da transformação da consciência, o que desembocou em atitudes como o ativismo em prol da preservação dos recursos naturais do planeta, a rebelião coletiva na qual tiveram participação, ajudando a deflagrar (junto com outros fatores sociais) a mentalidade presente na contracultura e demais protestos juvenis dos anos sessenta e setenta. O movimento beat expressa o espírito romântico da poesia enquanto ação, discutido por Octavio Paz no já referido Os Filhos do Barro.

O peculiar misticismo de Allen Ginsberg, ao ver o poeta como sacerdote, em poemas como "Morte à orelha de Van Gogh" (2005, p. 125), remete à visão demiúrgica do poeta, presente em românticos como Blake, ${ }^{39}$ Novalis e Shelley. Tal concepção encara o poeta como uma espécie de mágico, xamã e visionário. Por mais que seja problemática, por remontar a uma ideia frágil e burguesa do artista como ser à parte,

\footnotetext{
${ }^{39}$ Temos consciência de que, na história da literatura inglesa, William Blake seria considerado préromântico, porém, sendo conhecida a consonância de suas ideias com as matrizes teóricas do romantismo da forma como é apresentada por Octavio Paz em Os Filhos do Barro, achamos desnecessárias as possíveis digressões sobre o assunto.
} 
essa atitude implicou participação e consciência histórica. Associada ao entrelaçamento da literatura e da arte com o erotismo, à atividade e ao prazer sexual, essa ideia promove, na poesia beat, uma constante sacralização do erótico (mesmo quando vislumbra o deboche) que converge com a erotização da vida e a constante poetização da experiência vivida. Tais concepções, como nos mostra Willer (2009) promovem ainda a projeção de dois planos na produção poética: o do amor libertino, e do amor totalizante defendido pelos surrealistas, fundamentando essas questões, muitas vezes num homoerotismo ostentado como experiência de exceção. É sob esse viés que buscam a correspondência entre corpo e signo.

A tradição romântica, fundada no pensamento analógico, convergindo, de certa forma com a rebelião e a imagética surrealista, juntamente com a ênfase beat no comportamental, na musicalidade e no apelo à corporeidade e erotização do signo, parece ser um fundamento que os poetas que aqui constituem nosso objeto de estudo procuram frequentemente interrogar e transcender, em constante diálogo. Nesse empreendimento que associa erudição e culto ao irracionalismo, vemos um trabalho artístico que mostra o desejo de se intensificar na práxis vital.

O primado da imaginação - instrumento propiciatório e analógico - parece ser um princípio ético para Claudio Willer no intuito de "Transformar o cotidiano em hipérbole, labirinto onde todos se perderão brincando despreocupadamente" (2004, p.40). Em Piva, encontramos princípio semelhante, pois o sujeito poético se empenha em "abandonar tudo. conhecer praias. amores novos./ poesia com cascatas floridas e aranhas/ azuladas nas samambaias" (2006, p.112).

A imagem poética e o discurso ambivalente em Piva remontam à poesia de surrealistas como Robert Desnos. Em Piva, temos: 
Os corações árticos coçavam suas cabeleiras cultivando a morte Gotas de meninos morenos mudados em nevoentos cascalhos de desolação nas montanhas murchas de luar onde a lembrança é cinzenta correndo teu arco na tempestade solar da incerteza o dia escurecia a auréola dos mortos descobridores de mágicas

(“Piazza IX”, Roberto Piva, Piazzas, 1964)

Embora se possa inferir daí uma atmosfera dada pela cadeia semântica, o referente não está entregue - é fugidio. A força do poema, seu efeito sobre leitor, a emoção e experiência que o texto é capaz de causar se dá por modulações, pela perspectiva cambiante das imagens: coisas que se prismam numa sequência de metamorfoses (“Gotas de meninos mudados em nevoentos cascalhos da desolação").

Em Desnos, joga-se com elementos semelhantes, sobretudo com a sobreposição imagética em tom de relato onírico. O alargamento verbal, semelhante ao de Piva é notório:

Os discípulos da luz jamais inventaram senão trevas pouco opacas

O rio rola um pequeno corpo de mulher e isso significa que o fim está próximo

A viúva em vestes de núpcias se engana de carro

Chegaremos atrasados ao nosso túmulo.

Um navio de carne se afunda sobre uma pequena praia. O timoneiro convida os

passageiros a se calar.

(Robert Desnos, "os grandes dias do poeta") ${ }^{40}$

Composições desse tipo tem relação com as sequências de imagens oníricas nas quais as coisas aparentemente mais distintas correspondem-se em uma mesma cena, ou, neste caso, em um mesmo enunciado. Remonta aos "belos como" dos Cantos de

\footnotetext{
${ }^{40}$ As traduções de Robert Desnos por Eclair Antonio Almeida Filho, que aqui citamos, encontram-se inéditas. Foi-nos gentilmente cedida pelo mesmo.
} 
Maldoror (LAUTRÉAMONT, 2005). Nos Cantos, obra de importância basilar para os surrealistas, há algo como uma orgia do pensamento analógico. As comparações rompem os nexos previsíveis e extrapolam as noções de contradição e sentido. Assim, há comparações como: "O escaravelho, belo como o tremor das mãos no alcoolismo" (2005, p.223). E o célebre "Belo como o encontro fortuito sobre uma mesa de dissecção de uma máquina de costura e um guarda-chuva" (2005, p.252).

Os poemas em prosa de Willer mostram também bastante semelhança com o ímpeto de alargamento verbal de Robert Desnos, o qual indubitavelmente deve seu tributo a Lautréamont. Assim, em A liberdade ou o amor, de Desnos, temos:

O vento trazia folhas arrancadas das árvores das Tuileries e estas folhas caíam com um ruído macio. Eram luvas; luvas de todos os tipos, luvas de pele, luvas da Suécia, luvas de fios longos. Diante do joalheiro está uma mulher que tira sua luvas para experimentar um anel e para ter a mão beijada pelo Corsário Soluço, é uma cantora, no fundo de uma teatro agitado, vindo com eflúvios de guilhotina e gritos de Revolução, é o pouco de uma mão que podemos ver no nível dos botões. De vez em quando, mais pesadamente que um meteoro em fim de curso, caía uma luva de boxe. A multidão pisava nesses mementos de beijos e de abraços sem lhes prestar a deferente atenção que elas solicitavam. Só eu evitava matá-los.

Em Willer:

A noite, aos poucos, fechava sua mão de nebulosa ao meu redor e tudo eram apelos, chamados, gritos audíveis, desejos de amor ao nível das carícias pornográficas, através da porosidade dos portões, da familiaridade das frestas e janelas ovais.

(“Subúrbios da mente”, Anotações para um apocalipse, 1964);

A cidade e seu esqueleto múltiplo e inevitável, seus animais incendiados e turbilhões de fomes sem fim. Dentro dela o grande estômago absorvendo todas as contemplações. Vitrais pulverizados envolvem os grandes prédios, a magia coloca-se ao alcance de todos sob a forma de um corrimão que aponta para a morte da Perspectiva. 
(“O serpentário e suas ramificações”, Dias circulares, 1976).

Em seu primeiro livro, Paranoia, Piva alia o verso longo (quase prosa que se sucede em blocos sucessivos) do poema "Uivo" (2005) de Allen Ginsberg, à imagética surrealista. Utilizando-se vastamente da forma enumerativa. Como podemos ver em:

fagulha de lua partida precipitava nos becos frenéticos onde vidro

cafetinas magras ajoelhadas no tapete tocando o trombone de da Loucura repartiam lascas de hóstias invisíveis

(“visão 1961”, 1964),

som morte tempo ossos verdes vontade energia e as habituais velhas loucas distribuindo bombons aos meninos pobres

minha vertigem entornando a alma violentamente por uma rua [estranha

(“L'ovalle delle apparizioni”, idem),

os insetos as nuvens costuram o espaço avermelhado de um céu sem [dentes

(“Rua das Palmeiras", idem)

É possível encontrar o mesmo recurso, mas numa perspectiva mais discursiva, em Willer:

nossos corpos rolando abraçados sobre este chão de cílios [vibratórios que recobrem a terra, esse balão luminoso que pisca na neblina

("é assim que deve ser feito" Jardins da provocação, 1981)

sua loucura que gosta de vestir-se de santa medieval, de dançarina [egípcia, de

[ camponesa boliviana, sua loucura envergando a máscara de [palha de um sacerdote africano

(“a verdade" Estranhas Experiências, 2004). 
A velocidade do verso beat, mostra-se no primeiro livro de Piva, como recurso adequado para expressar a ênfase no choque entre o indivíduo e a sociedade industrial. Podemos notar que a experiência piviana é análoga àquela do poeta beat Philip Lamantia em “Terror Conduction”, que nosso poeta ora transcreve, parafraseia, traduz. A título de comparação com Piva:

The menacing machine turns on and off Across the distance light unflickers active infinities Under the jangling hand set going in the brain menacing by white lacerations ${ }^{41}$ THE WOMAN THE MAN menacing in a timeweighed fishbowl of the vertical act and the woman and the man menacing together out of mutual crucifixions

disgorge

towers for the dead the woman menacing

the man menacing the woman and the man menacing together BUT

THE CROWDS

THE CROWDS MENACING as eyes take off for NOTHINGNESS in night rememorizing the primal menace on a day and a night crossed with butchering polite squeels humdrum

WHAT are all these

waywardlooking scorching haggard perilous witchlike criminal

SUBLIME

drunken wintered

GRAZING

FACES

FACES

going by

like icebergs

like music

\section{like boats}

like mechanical toys

LIKE

RAINING

SWORDS

\footnotetext{
${ }^{41}$ Os grifos são nossos.
} 
A imagem desesperada da cidade com a máquina miserável de suas multidões, esse território de terror povoado por personagens fantásticos, campo magnético no qual o sujeito se afunda em uma dor insuportavelmente prazerosa, faz com que o eu piviano reconheça sua experiência. Assim, podemos perceber a aparição das "brancas lacerações" da mulher ameaçadora de Lamantia no "poema da eternidade sem vísceras" de Piva, ${ }^{43}$ assim como as:

\section{FACES}

\section{FACES}

going by

like icebergs

like music

like boats

like mechanical toys

\section{(...),}

do beat, tornam-se em Piva:

almas

almas

como icebergs

como velas

como manequins mecânicos

(“Meteoro", Paranoia, 1963)

Daí que a própria constituição do eu, não raro despedaçado, partido, estilhaçado (como resultado do conflito) se configura como fio condutor das enumerações frequentemente dadas, como se vê no exemplo acima, numa aglutinação ininterrupta. O

\footnotetext{
${ }^{42}$ Cf. The new American poetry, 1945-1960. (p.154, 155) Org. Donald Merriam Allen: University of California Press, 1999.

43 "eu assistia uma guerra de chapéus e as brancas/ lacerações dos garotos do Ibirapuera angélico/ terreno vazio onde eu mastigava tabletes de/ chocolate branco" (Paranoia, 1963).
} 
que as fixa, muitas vezes, é o procedimento anafórico - garantindo intenso poder de canto a essa poesia:

Eu vi uma linda cidade cujo nome esqueci

onde anjos surdos percorrem as madrugadas tingindo seus [olhos com

lágrimas invulneráveis

onde crianças católicas oferecem limões para pequenos [paquidermes

que saem escondidos das tocas

onde adolescentes maravilhosos fecham seus cérebros para os [telhados

estéreis e incendeiam internatos

(...)

(“Paranoia em Astrakan”, Paranoia, 1963);

Eu vi os anjos de Sodoma lambendo

as feridas dos que morreram sem

alarde, dos suplicantes, dos suicidas e dos jovens mortos

Eu vi os anjos de Sodoma crescendo com o fogo e de suas bocas saltavam medusas cegas

Eu vi os anjos de Sodoma desgrenhados e violentos aniquilando os mercadores, roubando o sono das virgens, criando palavras turbulentas

("Os anjos de Sodoma", idem).

Procedimento usado às largas pelos surrealistas, a anáfora constitui um interessante elemento lúdico no ofício do verso. Figura como uma possibilidade aberta ao improviso, ao alargamento sem peias da fantasia, pois garante a imprescindível força rítmica desse jogo: o poeta pode vadiar à vontade com suas palavras-sem-rumo e com a surpresa, sem risco de que a brincadeira acabe. Há, nessa perspectiva, um tema que se desdobra em diversas voltas. Como se vê em Piva, cada novo verso sobre o "assunto" pontuado pela anáfora "onde" ou "Eu vi" abre para um desdobramento da imagem 
inicial. Assim, André Breton no célebre poema "A união livre" utiliza tal recurso como espinha dorsal de sua imagética:

Minha mulher com nádegas de arenito e de amianto
Minha mulher com nádegas de dorso de cisne
Minha mulher com nádegas de primavera
Com sexo de gladíolo
Minha mulher com sexo de mina de ouro e de ornitorrinco
Minha mulher com sexo de algas e de bombons antigos
Minha mulher com sexo de espelho
Minha mulher com olhos cheios de lágrimas
Com olhos de panóplia violeta e de agulha magnetizada
Minha mulher com olhos de savana
Minha mulher com olhos d'água para beber na prisão
Minha mulher com olhos de madeira sempre sob o machado
Com olhos de nível d'água de nível do ar de terra e de fogo. ${ }^{44}$

Trata-se de um procedimento sonoro e expressivo adequado aos voos da imaginação, pois funciona como coluna dorsal do improviso lírico, à qual este sempre pode voltar sem se desfazer no informe. À máxima liberdade analógica, à sucessão de imagens insólitas, faz-se necessário o pilar formal capaz de manter a obra de pé sobre sua própria constituição naturalmente caótica. Nos trecho de Piva, comparados ao de Breton, percebemos que há um tom mais agressivo, e que o fluxo dessa mesma agressividade impõe um apelo ao som inexistente no mentor do surrealismo. É o grito proveniente de uma amálgama verbal muito sensível ao caos urbano e às dilatações e retrações que experiências excessivas imprimem ao sujeito. O surrealismo de Breton, ao contrário do de Piva, que trabalha conjuntamente com fanopéia e melopeia, é alicerçado nesta primeira, focando-se assim quase que exclusivamente nas categorias imagéticas, não procurando, portanto, mimetizar sua revolta por recursos musicais da linguagem.

A intensa vocação sonora da poesia piviana tem encontro feliz com uma de suas mais fortes influências: a beat generation. Fortemente relacionados ao jazz, cuja

\footnotetext{
44 Tradução: Priscila Manhães e Carlos Eduardo Ortolan. Disponível em: http://www.revistazunai.com/traducoes/andre_breton.htm.
} 
fraseologia e gírias tocaram de modo marcante suas produções, os beats puderam, como leitores atentos do surrealismo, contribuir para um veio mais musical daquela vertente imagética própria de Breton e seus amigos. Assimilando sua plataforma libertária, a temática da loucura e o jogo livre de imagens, o movimento protagonizado por autores como Ginsberg, Jack Kerouac e William Burroughs, confere um caráter mais sensível à rebelião surrealista:

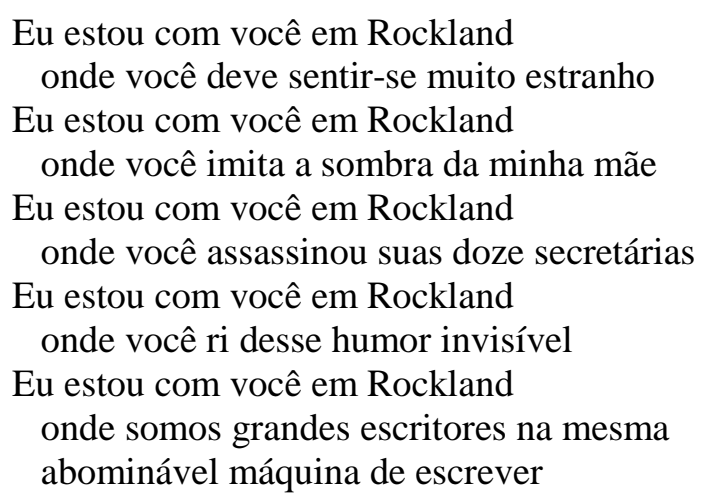

(Allen Ginsberg, "Uivo”, 1956).

Também aí o recurso anafórico do tema a conduzir as voltas. Nesse sentido é esclarecedora uma referência específica ao jazz na primeira poesia piviana:

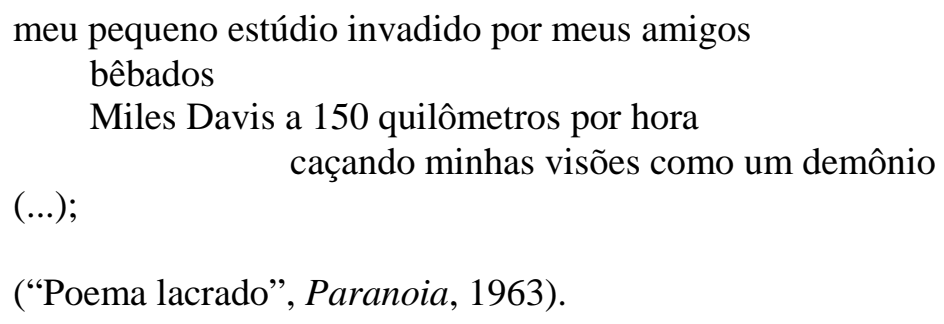

Atentemos para a menção à música de Miles Davis. A imagem que a configura no poema sugere que ao perseguir as visões do sujeito poético, essa música demoníaca, tentadora, está muito próxima ao seu processo de escrita. Duas forças: palavra e som, num mesmo movimento. Com um detalhe: som precede a imagem. É Miles que vai 
atrás das visões do sujeito e não o contrário. A partir daí consideremos que, de fato, um dos elementos mais fortes da poesia de Piva é a sua sonoridade. Tal característica é mostrada com precisão pelo ensaio "Vida experimental" de Carlos Felipe Moisés, cujo foco é a oralidade de Piva. Segundo o crítico essa "oralidade básica" teria um "intenso poder de canto". Como se o texto em seu suporte gráfico fosse "uma espécie de partitura, representação provisória das potencialidades de uma voz, ou vozes, que esperam ganhar existência efetiva, sopradas no ar de fora, em vez de serem moduladas pelo ouvido interior, intelecto adentro" (2001, p. 302). Assim, por fixar-se tão intensamente em nosso elemento básico de comunicação (a fala) essa poesia pede participação, o poeta parece querer que o leitor seja seu coadjuvante. E faz parte de um anseio por integração, daí que Carlos Felipe Moisés sugere que essa poesia subentende muitas vezes o canto coletivo. Basta ver como em vários momentos o poeta sacrifica o conceito deixando-se levar por uma combinação sonora - seja pelo jogo de palavras, seja pela aliteração, seja pela glossolalia. O murmúrio incessante vem aqui como batuque, ruídos mixados numa caixa de ressonância chamada poeta. O caráter irracional, tão enfatizado a respeito do autor se deve mais do que qualquer outra coisa à música própria de sua arte. O ritmo, como nos diz Octavio Paz chama à analogia, produz imagem. E o metrônomo de Piva é variado, sincopado, dissoluto.

Dessa forma, temas obsessivos voltam constantemente, o que nos lembra a leitura do conto $O$ Perseguidor de Julio Cortázar, feita por Davi Arrigucci Jr em seu livro O Escorpião encalacrado (1973). No capítulo “A destruição anunciada”, o referido crítico vê a experiência criativa do jazz man Johnny Carter, protagonista do conto de Cortázar, como metáfora do poeta e da criação artística. Esta consistiria numa busca incessante, uma perseguição que jamais finda, por ser seu objeto inalcançável. Seria, portanto, a imagem de uma arte livre, fundamentalmente analógica, que estaria 
mais para um projeto existencial de procura desesperada pela essência das coisas do que para a produção de obras. Do mesmo modo, o jazz representa para Piva um modelo de liberdade, caça infinita que se satisfaz nos lampejos provenientes do arriscado improviso.

No referido ensaio de Carlos Felipe Moisés, há ênfase na condensação e refinamento gradativo pelos quais passam a poesia de Piva com o desenvolvimento de sua obra. Assim, observamos que embora sua escrita mude ao longo do tempo, o fio condutor dessa poesia é mesmo a imagem. Seu princípio de composição imagética descende daquele de Pierre Reverdy, tal como citado por André Breton no primeiro manifesto do surrealismo:
A imagem é uma criação pura do espírito.
Ela não pode nascer de uma comparação, mas da aproximação de duas realidades mais ou menos afastadas.
Quanto mais as relações das duas realidades aproximadas forem longínquas e justas, mais a imagem será forte, mais emotiva e realidade poética ela terá. (BRETON, 2001, p.35).

A diferença se dá, no fato de que em Piva, assim como nos surrealistas, a imagem não é o produto de uma "criação pura do espírito", nasce, muito mais de uma experiência intensa, de forte exaltação ou emotividade como podemos ver nas experimentações em prosa surrealista de Piazzas:

Assim que o sol embaralhado nos seus cílios de bronze como um pequeno espanto nas folhas de luz afugenta os corações dos seus ninhos de crepúsculo o mundo vive na partitura sublinhada do meu sangue o seu único esplendor.

(“Slogan”, Piazzas, 1964). 
Claudio Willer nos mostra constantemente algo afim à referida identificação beat entre sexo e criação literária ${ }^{45}$ em uma erotização ritualística da experiência poética:

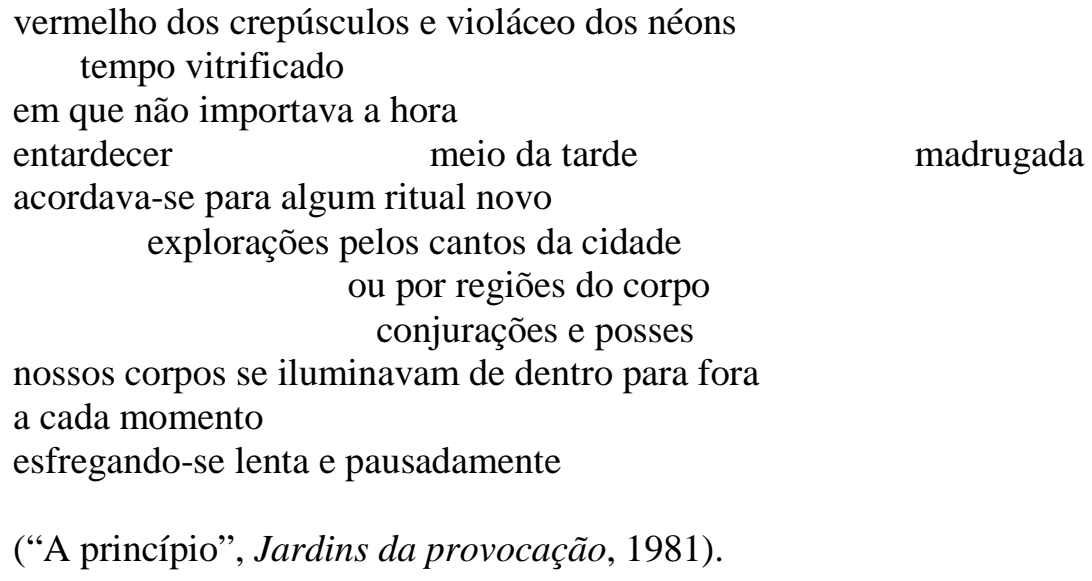

Nesse sentido, Piva concebe no homoerotismo descrito em seus poemas, um posicionamento ao mesmo tempo ético e estético diante de diversos males da modernidade, coloca-o, inclusive, em foco na sua tensa relação com a experiência urbana. Neste trecho de Coxas, a cidade capitalista com seu maquinário assustador é desafiada pela insolência adolescente dos dois garotos que se dedicam à intensa brincadeira amorosa:

O sol batia no edifício Copan suas rajadas paulistanas onde Pólen e Luisinho foram fazer amor e tomar vinho.

$(\ldots)$

Neste instante o helicóptero do City Bank se aproximava pedindo pouso e os dois nem ligaram continuando com suas blasfêmias heróicas e assassinas.

(“Escorpiões do sol”, Coxas, 1979).

\footnotetext{
${ }^{45}$ Que, de certa forma (ou com outras tintas) já está no surrealismo, como neste verso de Breton exaltado por Piva e Willer: "A poesia se faz na cama como o amor".
} 
As imagens esboçam a visão de mundo do poeta. São, como vimos, muitas vezes adensadas pelo alargamento, pela profusão verbal. Temos também, em alguns momentos como no livro Ciclones (1997), a alternativa da condensação, como podemos ver no poema que abre o livro:

$$
\begin{aligned}
& \text { esqueleto da lua } \\
& \text { o tempo } \\
& \text { tambor tão frágil } \\
& \text { vomitando a noite }
\end{aligned}
$$

(Ciclones, 1997)

A consciência rítmica manifesta-se primeiramente pela ênfase na sonoridade. Destaca-se a aliteração em $\boldsymbol{L}$ no primeiro verso e seu retorno no terceiro, porém o mais importante é a recorrência daquela em $\boldsymbol{T}$ que reproduz a batida do tambor ritualístico representado pelo tempo. As imagens do poema se sobrepõem seguindo na direção da imagem da noite regurgitada que emerge como espaço revelado pelo ritmo.

O tambor do Xamã, como nos mostra Eliade (2002), é o instrumento pelo qual este se concentra e restabelece contato com o mundo espiritual, preparando-se para a viagem anímica que está prestes a fazer. Assim, o eu poético dá as primeiras batidas rumo às visões que privilegia como forma de conhecimento.

Nessa perspectiva, em Para uma contracultura (1971), Theodore Roszak apresenta a problemática das várias manifestações jovens que então se davam nos Estados Unidos no final da década de sessenta e que consistiam em uma negação do estilo de vida capitalista, conduzindo, no entanto a outras formas de contestação, voltadas para uma busca de alternativas fora dos quadros tradicionais das esquerdas. Assim, Roszak expõe e analisa o psicodelismo, o interesse pelas doutrinas orientais, o LSD, a proliferação de textos de autores como Marcuse e Norman Brown (com ênfase 
na problemática libertária a partir da questão sexual) por ampla camada desses jovens, tratando do que há de potencialmente contestador e do que, no âmbito do poderio de assimilação do capitalismo, seria tão somente inconsequência a ser tragada pelo tempo.

Segundo o autor, esta cultura que buscava novas formas de percepção e de experiência estaria se voltando, na verdade, não necessariamente (ou pelo menos não diretamente) contra o capitalismo como sistema político em si, mas sim contra a tecnocracia. No último capítulo deste livro "O mito da consciência objetiva", coloca-se a questão de como os processos que regem a vida nas tecnocracias, são desconhecidos pelas pessoas que vivem sob eles, sob seus ditames. Assim, pairaria sobre as populações dos regimes tecnocratas (sejam de direita ou esquerda) uma espécie de sortilégio, responsável, inclusive, pela degradação da vida humana e pela destruição do planeta.

Desse modo, sob o regime da técnica seria consolidado, internalizado e aceito o status da alienação diante das determinações da própria existência. Por engendrar o divórcio litigioso da experiência em relação aos processos que regem a vida, a relação do homem com o mundo estaria essencialmente prejudicada. A tecnocracia consistiria assim em imiscuir na matéria mesma da vida um mito no qual as pessoas creem de modo autômato - por acreditarem-no capaz de guiar, para o bem do ser humano, e pela via objetiva, todas as situações. Assim, o distanciamento e o olhar a frio proporcionados pela ciência e pela técnica seriam absolutamente confiáveis. Isso, por não envolverem questões creditadas como falhas e parciais como a paixão, os sentimentos e as questões pessoais do individuo.

Assim, a barbárie da sociedade técnico-industrial em relação ao homem e à natureza, e, ainda, ao homem enquanto natureza estaria sancionada. Sendo assim, a relação do homem integrado (mesmo que inconscientemente) ao modo de pensar e 
sentir da sociedade técnica-industrial se dá por distanciamento em relação ao outro, deve ser racional, separada da natureza, divorciada do cosmos. Uma vez executada essa cisão, todos os mitos da tecnocracia podem agir despreocupadamente, como entidades abstratas que oferecem falsa inteireza - como, por exemplo, as táticas do consumismo ou das burocracias estatais dos governos totalitários.

Desse modo Roszak opõe ao referido mito (da consciência objetiva e infalível) aquele dos modos de vida arcaicos, remetendo à magia dos antigos xamãs. Não se trata de reverter um processo que seria irreversível como é todo o processo da civilização ocidental. O antropólogo propõe essa outra visão de mundo justamente como um modo de conceber e de lidar com a realidade, reconhecendo-se nela. Daí que evoca a sensibilidade romântica, cuja visão antropomórfica e panteísta estaria em continuidade com o pensamento arcaico. O sujeito, vendo e sentindo a si mesmo como parte integrante do universo superaria o status da alienação. O homem moderno, tal como os xamãs, se aproximaria de cada coisa com uma canção nos lábios. Manifesta-se assim o desejo contracultural de remitificar um universo desencantado pela técnica. É interessante como as estratégias poéticas de Piva condizem com tal tentativa:

Alma fecal contra a ditadura da ciência

Rua dos longos punhais

Garoto fascista belo como a grande noite esquimó

Clube do fogo do inferno: alquimistas xamãs

Templo

$$
\text { Beatniks (...) }
$$

Procissão do Falo sagrado

Deuses contemplam nas trevas o sexo do anjo do Tobogã

Felizes e famélicos garotos seminus dançam como bibelôs ferozes

Pedras com suas bocas de seda

Partindo para uma existência invisível

Tudo que chamam de historia é meu plano de fuga da civilização de vocês

(Ciclones, 1997) 
Ginsberg, mais uma vez no "Uivo", invectiva essa ordem, a qual constituiria o sórdido mito da destruição na figura do Moloch capitalista:

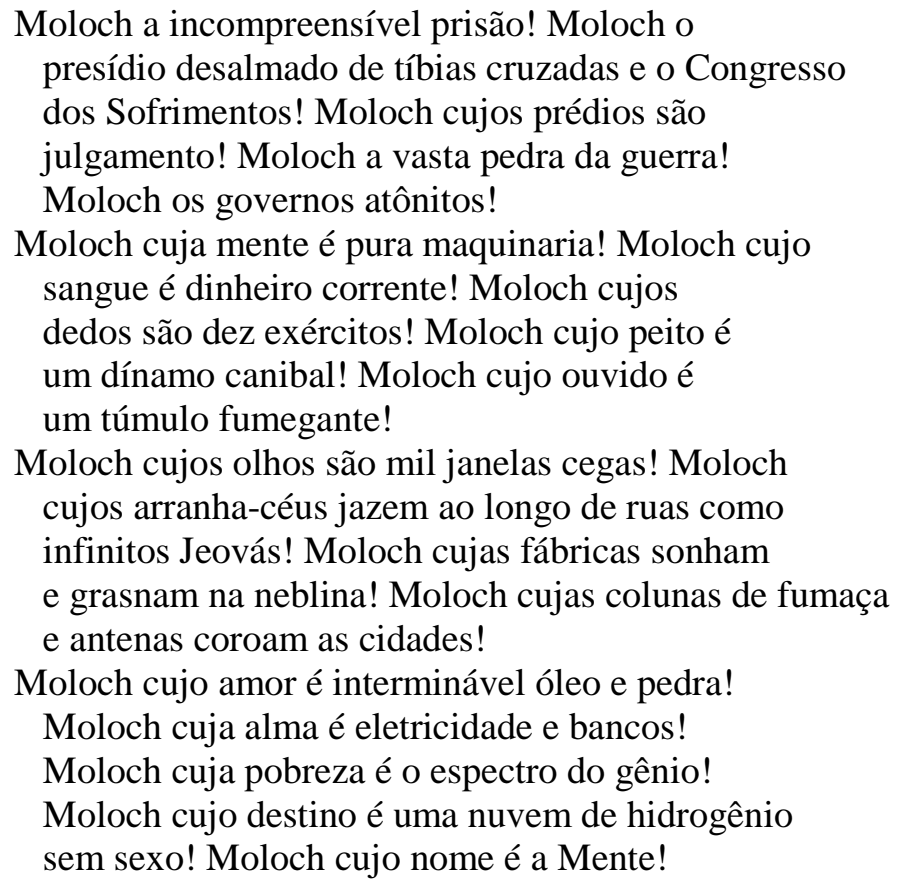

Willer, no poema "A verdade", publicado em Estranhas experiências, alude à experiência da loucura, dada pela impossibilidade de adaptação do indivíduo aos imperativos da ordem que Ginsberg faz-se representar pelo seu Moloch: acontecimento trágico protagonizado por muitos que viveram a contracultura nos anos setenta. Assim, o eu lírico insere-se entre os personagens que marcham em negação uníssona. Lúcido, no entrelugar, elogia entusiasticamente aqueles que passaram para o outro lado:

todos, todos eles

os que agora vagam pelas mesmas ruas

os personagens fantásticos os profetas do desencontro os poetas malditos os videntes os ensandecidos os marginais seus passos, nossos passos contraculturais e magníficos ecoam, ressoam, pelas ruínas do Ocidente

- todos - todos eles irremediavelmente enlouquecidos

(“A verdade", Estranhas Experiências, 2004). 
A paixão pela loucura representa ao mesmo tempo a negação de uma escala de valores reconhecidos no status quo. O poeta parece identificar esses personagens marcados pela marginalidade como correlatos de seu próprio ofício. Assim, a poesia identifica-se diretamente à utopia - figura como o lugar contracultural por excelência.

No manifesto da selva mais próxima, Piva afirma:

É do Caos, da anarquia social que nasce a luz enlouquecedora da Poesia/ Criar novas religiões, novas formas físicas, novos antisistemas políticos, novas formas de vida/ Ir à deriva no rio da Existência.

Esse viés em Piva se aguça a partir dos anos setenta, resultando em uma mitologia própria em que a adolescência figura como mitologia da transgressão. Assim, o homoerotismo da poesia de Piva intenta traçar uma experiência em tudo avessa à moral burguesa - à ordem "Kareta". Como afirma Eliane Robert Moraes, trata-se da "sensibilidade inquieta" que "vasculha a lascívia das ruas e das alcovas para então submetê-la ao incansável trabalho da alucinação, apostando no excesso como o único meio capaz de dar conta de uma vertigem a um só tempo erótica, estética e existencial" (2006, p.160):

adolescentes violetas na porta do cinema.

Bar Jeca esquina da São João/ Ipiranga

revoada de revoltados. Maravilhosos. Jamais capitular. pijamas, família, tv doméstica: a ordem Kareta se representa a si mesma.

corpo doce-delicado-quente na manhã alaranjada. o planeta entra na órbita do coração.

(XII, vinte poemas com brócolis, 1981) 
Certamente o que resiste no poema não é sua afirmação do homerotismo em detrimento da vida burguesa. Todos sabem que tal experiência - vista aqui em caráter de absoluta exceção - não tem o mesmo poder de chocar ou de se opor à moral vigente do modo como tinha há tempos atrás. A experiência de exceção em si ficou esvaziada (bandeira naufragando) no mar capitalista que tudo engole indistintamente. Mas os "adolescentes violetas" de Piva, do modo como aparecem, dados pela sequência de imagens tal qual no cinema a que o poema alude, fixam-se na realização estética. A condensação, o ritmo pausado em estilo telegráfico, o jogo de oposições que se dá entre a ordem "Kareta" e a "manhã alaranjada" elevam o suposto tema para além da ideologia que comporta.

Desse modo, a política piviana é declarada enfaticamente. Define a intensidade de uma batalha que se trava no âmbito do próprio corpo, no sentido de que encontrar vias de prazer corresponde a reverter o processo de reificação:

\author{
(A POLÍTICA DO CORPO EM FOGO DO CORPO EM \\ CHAMAS \\ DO CORPO EM FOGO) APAGANDO A LUZ as trevas \\ devoram \\ teu corpo em chamas tua boca aberta teu suicídio \\ de prazer na grama tuas mãos colhendo meu rosto \\ de folhas machucadas na escuridão teu gemido à sombra \\ das cuequinhas em flor \\ teus cabelos são solidamente negros.
}

(ABRA OS OLHOS E DIGA AH!, 1975)

Assim, o jogo de luz e escuridão na intensa e sôfrega aproximação do objeto de desejo conduz às próprias dificuldades dessa política, anárquica, erótica. As raias de tal posicionamento acabam quase que inevitavelmente no mito. Nesse sentido vê-se a arte, a poesia, o amor, como focos de resistência - o mito aproxima-se da vida no sentido de que permite a perseguição de uma prática cotidiana livre. 
A ânsia (mítica) de reintegração à vida orgânica que se mostra em certas passagens de Willer. A descrição de uma espécie de rito alucinatório, com frases dilatadas à cata de relações insólitas, esboça o ímpeto cósmico, no sentido de abarcar a totalidade impossível do universo fragmentado. Perfaz-se nessa via um clima míticoencantatório engendrado pelo tom altissonante do eu lírico, que revela a verve daquele "sentimento aristocrático do ser" e alude ao modo como este concebe a natureza, num misto em que prevalece a tensão entre cultura e instinto animal:

Inseguro entre o céu e a estepe, suspenso num fluir de roda gigante, embebido na minha nostalgia de centauros, eu devoro pedaços de musgo e raízes de plátano, estendido em jardins intermináveis onde se modelam arcanjos. Teria sido muito mais fácil escrever cartas de amor, para serem estendidas ao longo das estradas e pelas paredes dos tribunais - são inúteis para a vida, porém, estes poucos instintos que lentamente se devoram uns aos outros (...).

(“Uma fronteira para o grito", Anotações para um apocalipse, 1964);

Todo rio é um convite ao sobressalto, à morte através de chamas e venenos terríveis. Todo rio é um convite ao amor entre raízes milenares e campos roxos sulcados por veios de cristal (...).

(“O vértice do pântano", idem, 1964).

Piva sistematiza cada vez mais o vezo panteísta de sua poesia, que se intensifica na percepção da natureza como depositório do sagrado e do mistério, capaz de libertar e desobstruir a respiração do eu lírico (sufocada pelos ditames da sociedade técnica) que, como quem relata uma experiência sublime, manifesta-se numa dicção profética, marcada por disparos verbais de um íntimo ímpeto e pelas repetições e anáforas que pontuam e decantam o tema. O ritmo é do relato ou da exortação oracular que transmite verdades inauditas. Também aí, um viés aristocrático do ser - este contém a experiência de algo único que o individualiza:

Que você conheça o relâmpago

chamado mundo sombrio

Estremecendo na folha do seu 


$$
\text { coração }
$$

Que você conheça este relógio sem nuvens chamado morte

dependurado no planeta

como volúpia secreta

Que você conheça manguezais

$\&$ realidades não-humanas

que são a essência da Poesia

Que você conheça o sussurro do Sol

$\mathrm{Na}$ água ferruginosa dos seus olhos

(“A oitava energia", Ciclones, 1997)

Willer, em todo caso, parece partir de pressupostos semelhantes na ligação que estabelece entre criação poética e natureza. Alude à experiência do sagrado, reconhecido na mesma saudade mítica da unidade perdida, junto a um sentimento de perda irremediável. No poema Após uma manifestação em defesa da reserva florestal de Caucáia do Alto, Claudio Willer opõe à fragmentação da vida urbana, a Idade de Ouro, de antes do progresso da civilização cristã:

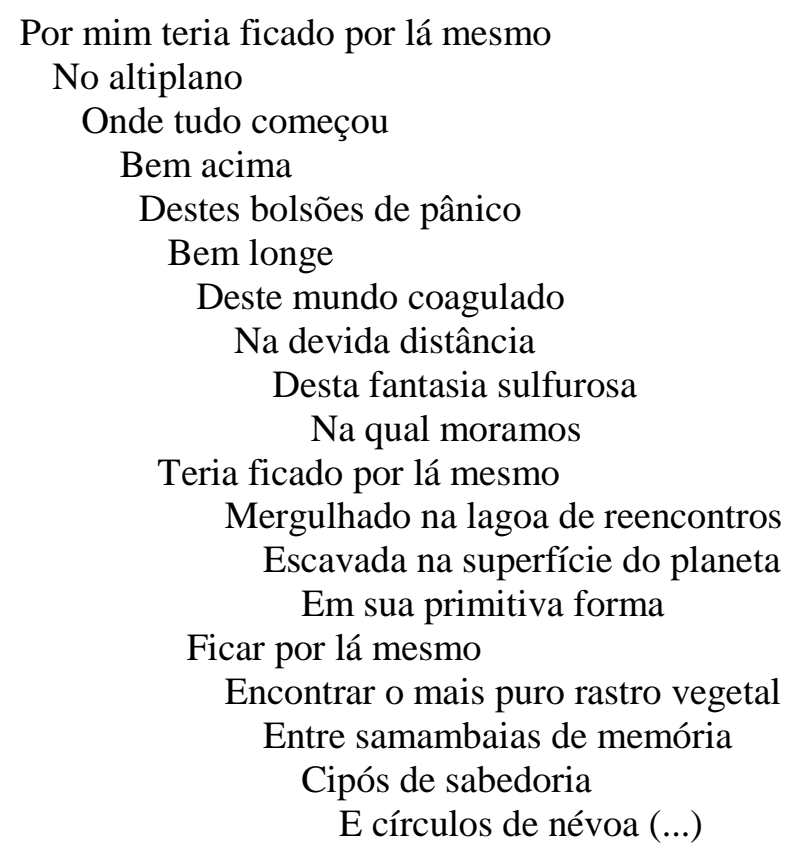

(“Após uma manifestação em defesa da reserva florestal de Caucáia do Alto", Jardins da provocação, 1981). 
Vemos que a ideia do retorno se configura na própria projeção gráfica do poema. Em cada estrofe os versos deslocam-se avançando com em uma escada, para voltar ao mesmo ponto em que se reitera o desejo de "ficar por lá mesmo". No paralelismo em que o poema se estrutura o mundo natural assume gradativamente os caracteres do mito. Isso, é importante ressaltar, se dá a partir do circunstancial. O poema, embora afirme pelo título tratar do relato de uma manifestação ecológica, não se refere diretamente ao fato.

Há, dessa forma, um intuito regressivo, que pretende resistir à possível captura do poético pela razão instrumental. Essa via conduz à visão da natureza como linguagem original. Para se falar, praticar a comunicação, torna-se necessário um retorno às origens:

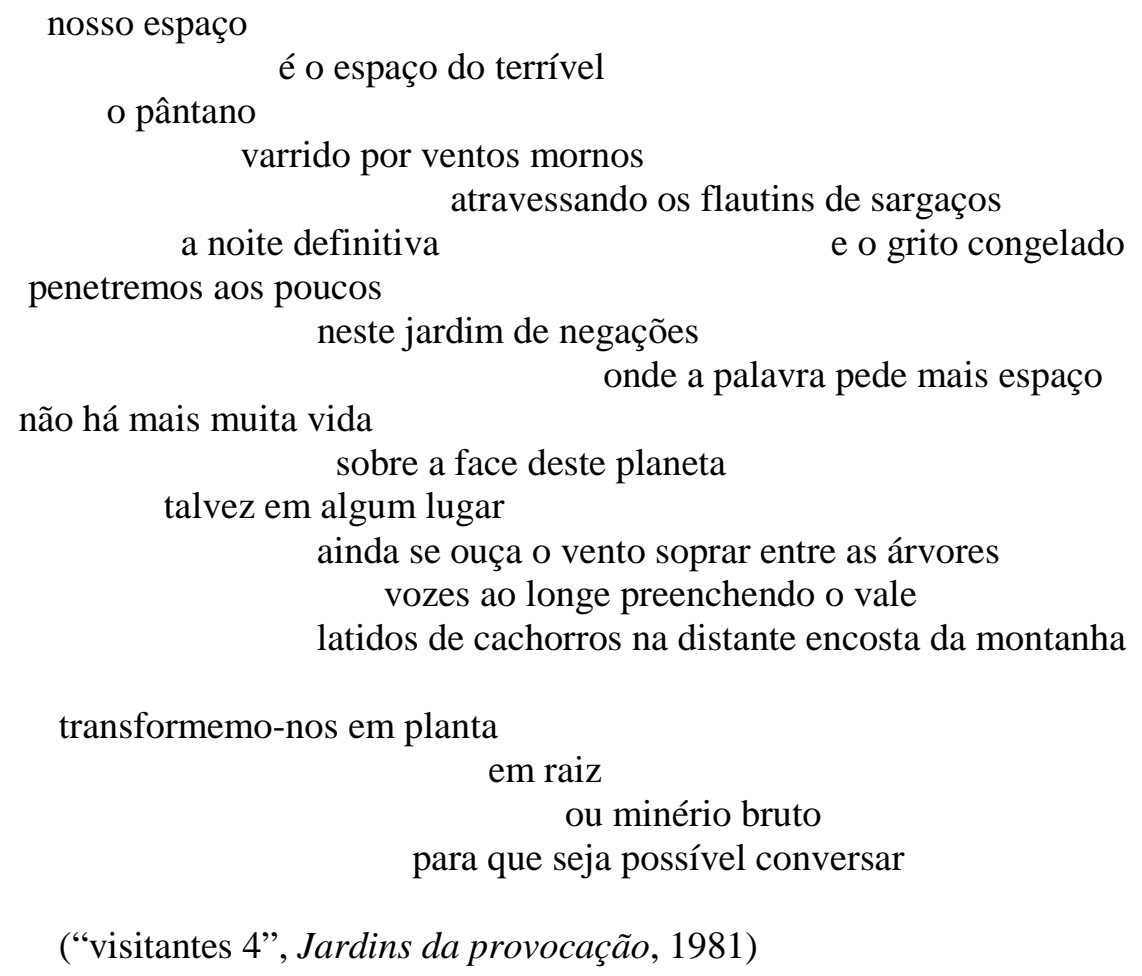

Nesse sentido, também, a poesia de Willer estabelece relação com a poesia de Piva. Neste último, a referida idade de ouro se localiza em território afim ao comentado 
acima:

Amando sobre a

Terra nua

Garras à mostra

No fundo azul da

Floresta

Amigo de todos os deuses

(Ciclones, 1997)

Este desejo de retorno manifesto pelo eu lírico propõe a busca pela revitalização da linguagem por meio da metamorfose, através da assimilação do sistema de signos do universo, com suas infinitas correspondências. Se o humano não é capaz de produzir linguagem, se o sufoco do utilitarismo da vida moderna tolhe a fala e não permite a conversa entre o sujeito e seu interlocutor, resta a imersão em outro sistema - não discursivo, irracional, espontâneo: analógico. Mas estes modos de pensar e sentir só podem ser almejados pelo artifício, pela cultura.

Nessa perspectiva, o combate com a ordem na poesia de Piva pode nos conduzir a mais referências interessantes para a compreensão de sua obra. Assim, a presença de blasfêmias como aquela em que "o universo é cuspido pelo cu sangrento de um DeusCadela", mostra como em algumas dessas imagens aparentemente gratuitas subjaz um aparato intelectual que serve como blindagem nas investidas do eu piviano. É que essa deidade canina foi saqueada do Pesa Nervos de um de seus ídolos, o já aqui mencionado Antonin Artaud:

Comigo deus-o-cão e sua língua que como uma flecha atravessa a crosta da dupla calote abobadada da terra que o exaspera.

(...)

Sob os seios da terra odiosa 
deus-a-cadela retirou-se

dos seios da terra e da água gelada

que apodrecem a sua língua oca. ${ }^{46}$

O poema piviano serve-se da imagem grotesca engendrada pelo criador do Teatro da Crueldade, na qual se evidencia o conflito entre o deus dessacralizado e a terra inóspita e terrível, no sentido de dar vasão à sua revolta e também de afirmar sua natureza dissonante frente àquilo que é considerado bom e aceitável pela normalidade vigente. Antes da referida imagem, o eu lírico de Piva declara:

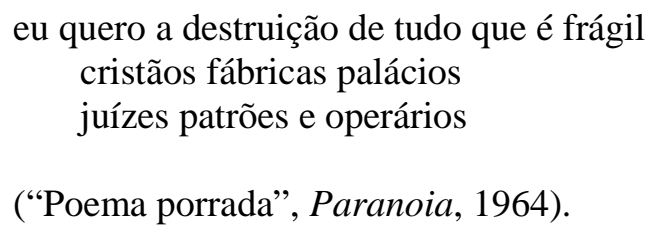

É interessante o fato de que os quadros de degradação e horror, embora acentuem um choque intenso marcado pela insatisfação do eu lírico, ostentam, como nos mostra Fábio de Souza Andrade em sua resenha sobre Paranoia, uma "demonstração orgulhosa da própria estranheza e excepcionalidade" (ANDRADE, 2000, p.76). Também, em sua poesia posterior, como neste poema de Coxas, podemos ver algo semelhante, insólitos relatos de orgia numa perspectiva a la Sade:

o leitão blindado dança no ziguezague de Hieronimus Bosch seu tango de petúnias o botão de controle da Sala de Torturas no porão do hospital é um olho parado amarelo vozes cachos de tâmaras tafetás rasgados de onde salta a noite gritos de garotos de botas e biquínis sendo flagelados por vinte putas alucinadas de cocaína

(“Norte/Sul”, Coxas, 1979).

\footnotetext{
${ }^{46}$ (ARTAUD, 1991, p.16).
} 
Em Willer, embora haja gosto por tal ética virulenta, as transgressões são veladas, pintadas com cores afins às paisagens sombrias de arriscados mergulhos no ser, esboça um eu lírico extático diante de taras e tabus:

O incesto é o sonho de uma matriz convulsiva e o mais profundo anseio das cigarras. Vaginas de cimento armado e urnas sangrentas, impassíveis contra um céu de veludo, guardiãs de oceanos impossíveis. Milhões de lâminas servem de ponte para os desejos obscuros - a mais afilada trará a nossa Verdade.

("Anotações para um apocalipse", Anotações para um apocalipse, 1964)

A figuração dessa vivência excessiva tem, por certo, um caráter artificial, pois reitera a excitação sem par na qual o sujeito se compraz quase como um maneirismo, embora uma dilatação da subjetividade, dada no jorro lírico, pretenda lançar ao leitor um eu levado à deriva do acaso de fluxos irracionais. Intentando ruptura com a sociedade, essa atitude perfaz uma busca por valores capazes de esboçar conduta condizente com o desejo do indivíduo. Remonta certas passagens de um vitalismo exacerbado que se vê em Assim falou Zaratustra de Nietzsche:

Volúpia: para a canalha, o fogo lento em que ela é queimada: a fornalha acesa e crepitante para toda a madeira podre, para todos os andrajos malcheirosos.

Volúpia: para os corações livres, a inocência e a liberdade, o jardim das delícias na terra, o transbordante agradecimento de todo o futuro ao presente. (NIETZSCHE, p.195)

Claudio Willer nos mostra esse sentimento aristocratizante de irradiação vitalista em trechos como este, em que se desnuda um eu voluptuoso, violentamente faminto pelas dádivas insondáveis da "inocência" e da "liberdade". É possível reconhecer ecos nietzschianos neste universo de fantasia livre, redentora:

As noites semimortas da minha adolescência, massacradas pela canalha, vieram pendurar-se nos meus ombros, arrastando-se, véu 
inútil, pelos complicados desníveis do Tempo Presente. Os seios de meia lua, lacerados, dinamitados, agora farpas de gelo acumulando-se em grossas camadas sobre os sofás, tapeçarias, lustres do meu quarto. Em compensação, todos os gatos esguios vieram acasalar-se à minha cabeceira, velando meu sono com seu lamento de fagote e harpa.

(“Anotações para um apocalipse”, Anotações para um apocalipse, 1964).

O ideário anárquico, não raro, intervém como afirmação temática de uma poesia aparentemente assentada sobre a não-referencialidade. Desse modo o estado de espírito oposto ao senso comum, institui a grandeza de uma subjetividade dilatada:

Cúmplice de conspirações subterrâneas e atentados noturnos, conivente com todas as armas fabricadas à mão, sorridente à hora de certos crimes espontâneos e meticulosos, sei que meu amor é uma advertência e um cravar de sulcos na superfície, e que meus passos sempre descreverão roteiros de tempestades, maresias e chuvas de ópio.

(“Subúrbios da mente”, Anotações para um apocalipse, 1997).

Esse lirismo marcado posteriormente pelo tom confessional, expressa também uma aguda percepção das propriedades musicais da fala. Dessa forma, explora o poder de canto e variações rítmicas da prosa. A transparência da confissão (arriscada, pois pode reduzir-se apenas a tal intuito) tende à sobreposição de dois planos: real/ imaginário:

Cruzo todas as vias deste bairro e passo por esquinas atentas. Prossigo em direção ao Sul: é sempre para o Sul, seja para qual direção for. Um simples Santo Amaro, este é o destino da vez, mas, ainda assim, sensação de perda, de que nunca chegarei a lugar nenhum ao passar por tantos lugares (todos) onde já estive (sempre), no automóvel que segue vagaroso, quase reverente: o automóvel é o navio fantasma, sou o personagem lendário, e sigo ladeado pelos tripulantes perdidos no tempo. São meus, estes fantasmas que me acompanham.

Mas o itinerante é belo.

E o poema de hoje à tarde, de há pouco, de agora

pois navego.

será perfeito,

Singro. 
Sempre em direção ao Sul.

hermético).

(este poema é

(“Na cidade", Estranhas experiências, 2004).

A afirmação entre parênteses que conclui o poema feito em linguagem direta mostra a concepção do eu lírico em relação ao mundo, segundo a qual este seria um sistema de imagens, um texto ao qual se acrescentam outros textos. Preexiste, na verdade, um aparato literário e artístico no olhar do sujeito. Nesse sentido são esclarecedoras as palavras de Marta Kawano em seu livro sobre o poeta Gerárd de Nerval:

(...) a junção da memória cultural com aquilo que se tem diante dos olhos propicia uma visão enriquecida da realidade, retirando-lhe um pouco da crosta de banalidade. Ou seja, quando o percurso da imaginação do poeta (suas lembranças, suas referências mitológicas e artísticas) cruza o percurso concreto do viajante, a realidade pode então dar abrigo à fantasia, ecoar as viagens da imaginação (KAWANO, 2009, p.210).

$\mathrm{Na}$ mesma perspectiva o procedimento imagético de Willer deita as luzes do imaginário (advindas do aparato simbólico do eu lírico) sobre a experiência concreta do cotidiano, no intuito de gerar uma atmosfera de fantasia, mas sem perder o viés representativo e expressivo como vemos no poema em prosa acima. Assim a poesia willeriana tende cada vez mais para o viés ensaístico, no qual se destaca a dimensão metalinguística de sua obra:

\footnotetext{
a sensação de estar aí mesmo

harmonia não necessariamente cósmica

plenitude muito pouco mística, porém simples proximidade

da aberrante experiência de viver algo como o calor

sentido ao lado de uma forja

(talvez devesse viajar, ou melhor, ser levado pela viagem, carregar tudo junto

deixar-se conduzir consigo mesmo)

ao penetrar no opalino aquário

(isso tem a ver com estarmos juntos)
} 
e sentir o mundo na temperatura do corpo

enquanto lá fora (longe, muito longe) tudo é outra coisa então

o poema é despreocupação

(“Poética", Estranhas Experiências, 2004).

Desse modo a reflexão sobre o ofício poético não se distingue da tessitura da memória, do amor e da comunhão erótica. A recusa a postular o problema da linguagem em si, apartado das relações de prazer, êxtase e entusiasmo é evidente. O discurso reticente, pontuado pelos comentários entre parênteses, mostram sensibilidade às propriedades poéticas da prosa cotidiana - parece dizer que o encontro, a aproximação do outro é que são importantes, sendo o texto escrito mero testemunho de uma experiência, que, por si só já contém o poético. Sob essa ótica o poema só interessaria como índice de transformações.

Trata-se então de engendrar uma vivência capaz de tomar para si a anarquia e o irracionalismo. Tal qual propunha Rimbaud com o "desregramento de todos os sentidos" através de um processo longo e raciocinado. Esse processo, em Willer, diz respeito diretamente à superação da miséria sexual imposta pela sociedade técnica. Por meio do lúdico e do prazer corporal e poético se criaria uma arte livre, espontânea, alucinatória. A questão não é se abandonar ao irracional - é chegar até ele. O espontâneo, o improviso e o desregramento devem ser conquistados. Nesse sentido o situacionista Raoul Vaneigem dá-nos uma interessante definição do que seja a espontaneidade, bem típica da mentalidade contracultural daqueles anos e oposta em tudo a concepções de arte mais tradicionais:

Spontaneity is the true mode of being of individual creativity, creativity's initial, immaculate form, unpolluted at the source and as 
yet unthreatened by the mechanisms of co-optation. Whereas creativity in the broad sense is the most equitably distributed thing imaginable, spontaneity seems to be confined to a chosen few. Its possession is a privilege of those whom long resistance to Power has endowed with a consciousness of their own value as individuals. In revolutionary moments this means the majority; in other periods, when the old mole works unseen, day by day, it is still more people than one might think. For so long as the light of creativity continues to shine spontaneity has a chance. (VANEIGEM, 2001, p.194)

Se por meio de uma longa resistência ao poder e tomada de consciência em relação a si e ao mundo o poeta consegue reformular sua própria subjetividade e alcança-la de acordo com a depuração do desejo, então está apto a criar livremente, espontaneamente. Mas, perguntaríamos, seria lícito acreditar-se tão apartado dos ditames da sociedade utilitária? Não se prescindiria aí de uma dúvida em relação a si mesmo essencial para que se tenha uma visão crítica da própria produção?

A problemática advinda da influência do surrealismo e da geração beat em Piva e Willer se faz válida na medida em que serve de correlato às suas experiências enquanto sujeitos, fomentando suas obras. Tal influência não se reduz à repetição de procedimentos, nem à imitação. Consideramos tratar-se de uma resposta às suas próprias aspirações artísticas. O elo com o romantismo que coloca o pensamento dirigido em dúvida e focaliza as questões em torno do eu, parece ser, em suas obras, uma alternativa de resistência ao esmagamento do indivíduo.

Apesar de uma leitura que enxerga em autores que flertam com o irracional ou o "desregramento dos sentidos" uma atitude de selvageria desprovida de concepção (cujo exemplo recente mais claro é a resenha da terceira edição de Paranoia publicada por Luís Costa Lima na Folha de São Paulo, na qual o crítico atribui, ironicamente, ao livro de Piva o mérito de fazer o delírio passar-se por poesia), ${ }^{47}$ percebemos que as produções

\footnotetext{
${ }^{47}$ Caderno Mais! 17 de janeiro de 2009.
} 
de Piva e Willer obedecem a uma forma característica de composição fomentada pela multiplicidade de leituras e longa convivência com a linguagem. Acreditar no viés irracionalista de Piva ou na apologia ao poema como "despreocupação" de Willer, assim como na recodificação que este tenta fazer da arte do companheiro, quase postulando uma Arte Poética a partir da mesma, seria esvaziar as obras de ambos da contribuição que podem oferecer, da tensão que se mostram capazes de instaurar em concepções tidas como inquestionáveis no âmbito da problemática em torno do valor literário.

Assim, faz-se necessário buscar alguns pontos em que se esboçam as concepções de Piva e Willer sobre a literatura, a fim de indagar sobre o que de fato se efetiva enquanto criação e quais seriam os tópicos restritos apenas ao discurso programático. 


\section{III - DE BRUXOS E POETAS}

Ao falarem sobre seus respectivos processos de criação, Willer e Piva remetem constantemente e de modo enfático, por vezes temerário, ao caráter não dirigido de suas produções. Ostentam, em certos momentos, exacerbada fascinação pela ideia da escrita como transe, experiência de exceção. Não economizam assim no elogio ao vaticínio.

Willer, na sua apresentação a Estranhas Experiências, mostra-se entusiasta das “virtudes proféticas da escrita espontânea, automática, delirante” (WILLER, 2004, p.13). Questionado sobre esse assunto em entrevista, afirma que "A frio, do tipo "vou escrever um poema’, não dá, não sai nada. Tem que haver entusiasmo, no sentido grego da palavra, como embriaguez ou possessão (...)". ${ }^{48}$

Também Piva, em entrevista recente, mostra-se em total harmonia com a postura de seu companheiro de geração ao dizer que seus poemas vêm daquela "vertente cósmica, onde nós pegamos toda a inspiração e a transformamos em matéria prima da poesia". ${ }^{49}$ Diante dessa afirmação podemos nos questionar: não haveria aí arriscada idealização do ato de escrever? Pode-se enxergar algo de regressivo, negligente ou ingênuo em tais afirmações enunciadas como profissão de fé por um poeta contemporâneo. Parece haver um endosso daquele estereótipo ultrapassado, tão combatido por boa parte da poesia do século XX: o poeta possuído pelos deuses, deslumbrado e febril, o romântico arrastado pela torrente irresistível de suas próprias emoções. Ora, sabemos que a concepção desses poetas, cada uma resolvendo-se de uma

\footnotetext{
${ }^{48} \mathrm{http}: / /$ www.elsonfroes.com.br/cwillerent.htm.

${ }^{49}$ http://telescopio.tipinhus.com/entrevista.htm.
} 
forma, dispõe de informação suficiente para fugir de tais armadilhas. Sendo assim, uma afirmação da poesia nesses termos não seria uma encenação, mera pose provocativa? Caso tal hipótese esteja correta, não poderia essa estratégia cair em uma cilada? Posto que a imagem do poeta inspirado, extremamente vitalista, louco, pirado, embriagado agrada bem ao burguês faminto por emoções fortes.

Nos poemas em que Piva e Willer expõem suas visões a respeito da poesia parece acirrar-se a mencionada concepção, que carrega consigo uma atitude específica para com a escrita no sentido da copiosa ênfase na relação visceral entre literatura e vida, o que desemboca em peculiar misticismo voltado para a experiência erótica e para a marginalidade. No livro Ciclones, cuja primeira edição se dá em 1997, Piva conclui que "poesia é desatino/ abrindo a Noite/ no excesso do Dia” (2008, p.40), e que:

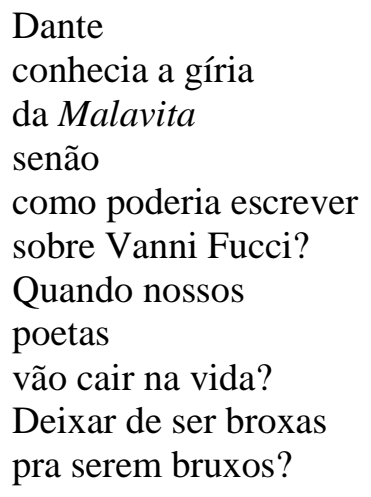

(Ciclones, 1997).

Não deixa de ser uma postura radical por parte do autor, considerar imperativo tão exigente e ao mesmo tempo tão relativo (pode-se "cair na vida" de várias formas como definir sob um só viés a experiência individual?) como categoria determinante para avaliar um poeta. Então, conhecer a linguagem da malavita, vivenciar o submundo habitado por figuras como o ladrão Vanni Fucci do inferno de Dante e correlatos, equivaleria a um acesso privilegiado ao poético? O poeta que, ávido pelo desconhecido, 
se lança nessas zonas de experiência torna-se mesmo um bruxo? Em que, necessariamente, isso consistiria em um mundo esvaziado de sentido, de utopias, em que se vende toda espécie de crenças e salvações coletivas em catastrófico atacado de encantos? O poeta parece querer persuadir, quer que acreditemos nele, tem uma verdade a dizer e, na violência da abordagem, revela-se difícil entrar no poema sem antes pactuar com a atitude sedutora do enunciador. É o que podemos perceber em passagens como:

\author{
seja devasso \\ seja vulcão \\ seja andrógino \\ cavalo de Dionysos \\ no diamante mais precioso
}

(Ciclones, 1997)

O eu poético de Piva não pressupõe um leitor, deseja um cúmplice, um aliado que se entregue incondicionalmente à sua causa: a poesia como tábua de salvação em meio à avalanche de destroços do mundo. Trata-se de disseminar o êxtase experimentado pelo poético (visto como instrumento de libertação) no intuito de perturbar a opaca realidade.

Provavelmente o radicalismo do poeta pode ser antes um ponto de vista meramente individual passível de discussão, sobretudo (e talvez somente) no âmbito de como isso se constitui em relação a outros textos. ${ }^{50}$ Pode cair em uma espécie de formalismo. Nesse sentido o poema em questão fica exposto ao risco no próprio despojamento da linguagem, na aparente gratuidade do enunciado. Sua referência a Dante pode, inclusive, soar como pedantismo caso seja descolada do restante de sua obra. Diante da conhecida exigência piviana de que um poeta experimental deve ter uma

\footnotetext{
${ }^{50}$ No poema aqui discutido sobre os "broxas e bruxos", Piva alude indiretamente a um texto de Pier Paolo Pasolini em que este fala do "mimetismo" de Dante: ao pesquisar a riqueza linguística da Divina Comédia, o poeta, ensaísta e cineasta italiano teria constatado que o florentino conhecia detalhadamente a linguagem da criminalidade da era medieval. Teria, portanto, vivido realmente aquilo que escreveu.
} 
vida experimental, parece-nos que aqui o problema é acima de tudo literário, propriamente artístico e genuinamente intelectual, pois, ao declarar seus princípios libertários o poeta tece uma teia de textos que retorna quase que inevitavelmente à problemática em torno da cultura escrita - verdadeira biblioteca de Babel - que constitui também a realidade que este deseja desmantelar.

Há, porém, os momentos em que a experiência de leitura mostra-se de tal modo íntima que engendra uma combinação inusitada de termos, desdobrada em imagens:

foi no dia 31 de dezembro de 1961 que te compreendi Jorge de Lima enquanto eu caminhava pelas praças agitadas pela melancolia presente na minha memória devorada pelo azul eu soube decifrar teus jogos noturnos indisfarçável entre as flores uníssonos em tua cabeça de prata e plantas ampliadas

(...)

é neste momento de fermento e agonia que te invoco grande alucinado querido e estranho professor do Caos sabendo que teu nome deve estar como um talismã nos lábios de todos os meninos

(“Jorge de Lima, panfletário do caos", Paranoia, 1963)

Ao se referir a Jorge de Lima, percebemos o intenso lirismo com que o eu poético descreve o autor de Invenção de Orfeu com a "cabeça de prata e plantas ampliadas", como o "grande alucinado", concedendo ao mesmo o atributo de "professor do Caos". Esses elementos seriam muito bem aplicados ao próprio eu que se configura ao longo do poema com sua "memória devorada pelo azul", percorrendo as "praças agitadas pela melancolia presente". Vemos que este encontro se efetiva. A esfera da vida faz-se presente no texto justamente porque este se realiza artisticamente. Assim, notamos o referido desdobramento imagético e também os recursos sonoros, como as aliterações, constantemente utilizadas por Piva: "enquanto eu caminhava pelas PRaças agitadas pela melancolia PResente”. Há uma dimensão prosódica que lembra certas passagens do "Uivo" de Ginsberg como "who poverty and tatters and hollow-eyed and high sat up 
smoking in the supernatural darkness of cold-water flats floating across the tops of cities contemplating jazz". O tom de sôfrega intensidade lírica também ecoa a voz desesperada do Garcia Lorca de "Poeta em Nova York":

Tenía la noche uma hendidura y quietas salamandras de marfil. Las muchachas americanas llevaban niños y monedas em el vientre, y los muchachos se desmayaban em la cruz del desperezo.

(“Oda al Rey de Harlem”, Poeta en Nueva York)

Análoga à invocação de Jorge de Lima (embora sob uma ótica mais contemplativa) temos a presença de Murilo Mendes, como propiciador de visões. Mais um dos guias pivianos:

$$
\begin{gathered}
\text { mestre Murilo Mendes tua poesia são } \\
\text { os sapatos de abóboras que eu calço } \\
\text { nestes dias de verão. } \\
\text { negócio de bruxas. } \\
\text { o sol caía na marmita do } \\
\text { adolescente da lavanderia. } \\
\text { você veria isto com } \\
\text { seu olhar silvestre. } \\
\text { um murro bem dado no vitral } \\
\text { que eu mais adoro. }
\end{gathered}
$$

("VII", vinte poemas com brócoli, 1981)

O jogo de referências instiga-nos, pois o Murilo Mendes a que o eu lírico alude aparece de modo inusitado, sua poesia "são os sapatos de abóboras que eu calço". Tal perspectiva anárquica promove contextos diversos para a leitura, remonta assim ao conceito de colagem do pintor surrealista Max Ernst, que se pode inferir do modo como Piva trabalha com suas citações, intertextos e com a tradição literária presente em sua obra de um modo geral. No texto "Nascimento da Colagem" Ernst dá a entender a natureza deste processo:

Num dia chuvoso, em Colônia, o catálogo de uma casa que vende material escolar desperta-me a atenção. Vejo ali exemplares de todos 
os gêneros, manuais de matemática, de geometria, antropologia, zoologia, botânica, anatomia, mineralogia, paleontologia, etc., elementos de naturezas tão diversas que a absurdidade do seu reagrupamento me perturba a vista e os sentidos, desencadeando em mim alucinações e conferindo aos sujeitos representados uma sucessão de significados novos e mutantes. A minha atividade visual ficou de repente tão agudizada que consegui ver os objetos que se formavam imediatamente sobre um fundo novo. Para o fixar bastava um pouco de tinta, algumas linhas, um horizonte, um deserto, um céu, uma divisória ou coisas idênticas. Assim se fixou a minha alucinação.

(apud, Braune, p.39)

A "absurdidade" do "reagrupamento", de "elementos de naturezas tão diversas" assim como o teor alucinatório deste método fazem-se ver no modo como Piva recria seus poetas-personagens, fazendo-os viver situações as mais insólitas, acrescentando dessa forma significado àquilo que criaram, perturbando a estagnação dos registros ao fixar perspectivas múltiplas em suas citações. Delirar, nesse sentido, pode ser também, uma maneira de reescrever e, consequentemente, vivificar o verbo:

A estátua de Álvares de Azevedo é devorada com paciência pela paisagem [de morfina

a praça leva pontes aplicadas no centro de seu corpo e crianças brincando

na tarde de esterco

Praça da República dos meus sonhos onde tudo se faz febre e pombas crucificadas onde beatificados vêm agitar as massas onde Garcia Lorca espera seu dentista

\section{(...)}

os veterinários passam lentos lendo Dom Casmurro há jovens pederastas embebidos em lilás e putas com a noite passeando em torno de suas unhas há uma gota de chuva na cabeleira abandonada enquanto o sangue faz naufragar as corolas Oh minhas visões lembranças de Rimbaud praça da República dos meus

Sonhos última sabedoria debruçada numa porta santa

(“Praça da República dos meus sonhos”, Paranoia, 1963) 
Piva, ao fazer apologia do poeta-bruxo, esboça ao mesmo tempo sua ideologia existencial e um pressuposto estético. Parecem ser indissociáveis as experiências visionárias, os delírios, as incursões pela marginalidade e a crença exaltada na verdade emotiva dessas vivências cujo paradigma é a leitura: a fragilidade desse método pode consistir no fato de que a mensagem que deseja passar venha a se sobrepor ao meio do qual se utiliza e de que, fiel a seus princípios, o poeta deixe de galvanizar o leitor ao prescindir do artístico em prol do ideológico, mesmo que os dois tencionem a fusão.

A magia da linguagem deve criar seu próprio universo. O poeta e o mago teriam em comum uma relação peculiar com o verbo. As comparações traçadas por Octavio Paz em O Arco e a Lira (1982) confrontam a natureza das duas atividades:

As fontes do poder mágico são duplas: as fórmulas e demais métodos de encantamento, e a força psíquica do encantador, a afinação espiritual que the permite fazer concordar seu ritmo com o do cosmos. $\mathrm{O}$ mesmo se verifica com o poeta. A linguagem do poema está nele e só nele se revela. A revelação poética pressupõe uma busca interior. Busca que em nada se assemelha à análise ou à introspecção; mais que busca, atividade psíquica capaz de provocar a passividade própria ao surgimento de imagens. (PAZ, 1982, p.65).

É possível reconhecer no trecho de Paz uma alusão indireta à escrita automática dos surrealistas. Parece considerar necessário certo rigor, não formal, mas subjetivo, preexistente, para essa atividade. O autor observa, nessa perspectiva, elementos de fundamental importância para nossa abordagem. Trata-se da "afinação espiritual" que permite ao mago "fazer concordar seu ritmo com o do cosmos", sendo esta análoga à passividade provocada que permite ao poeta tornar-se instrumento propício ao surgimento de imagens.

Também nas analogias desenvolvidas em $O$ Arco e a Lira há referência ao mago como rebelde comparando essa condição à do poeta no mundo moderno. Há ênfase no 
conflito entre o sujeito e o objeto, entre o eu e o mundo. Octavio Paz demarca especificidades e conclui, enfim, que "O poeta não é um mago, porém sua concepção da linguagem como uma society of life - segundo define Cassirer a visão mágica do cosmo - o aproxima da magia." (1982, p.68).

É pelo mesmo território que Willer, em seus poemas, conduz a problemática da criação literária, da qual parece esquivar-se, abordando unicamente o aspecto existencial da questão. Procura a correspondência entre signo e corpo:

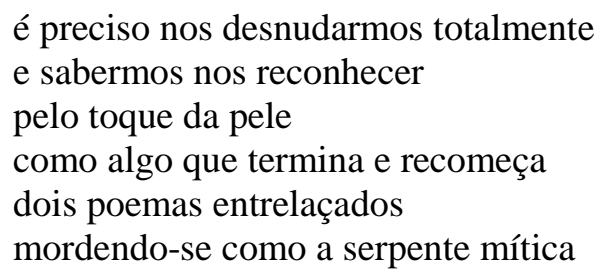

("Faz tempo que eu queria dizer isto", Jardins da provocação, 1981).

Sua poesia, no entanto, parece escorregar quando o entrelaçamento dos dois planos, o simbólico e o corporal não consegue dar-se, justamente devido a uma camada intelectual que se coloca entre o eu poético e a experiência:

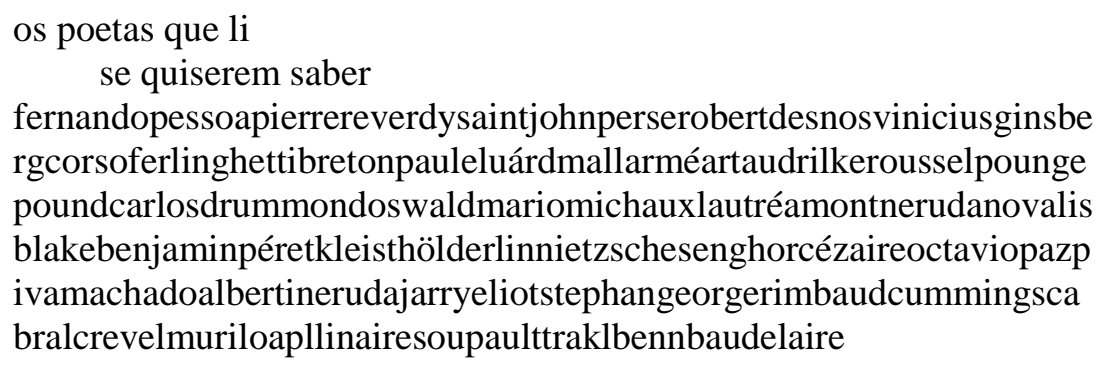
rgcorsoferlinghettibretonpauleluárdmallarméartaudrilkerousselpounge poundcarlosdrummondoswaldmariomichauxlautréamontnerudanovalis blakebenjaminpéretkleisthölderlinnietzschesenghorcézaireoctaviopazp ivamachadoalbertinerudajarryeliotstephangeorgerimbaudcummingsca bralcrevelmuriloapllinairesoupaulttraklbennbaudelaire

(“A princípio”, idem)

Mas a arte é o modelo da liberdade. É a arma do poeta bruxo. O perigo dessa utilização, como se vê na lista de nomes de autores acima, é que, como vimos em Piva, essa relação pode prescindir da vida quando as leituras caem como cortina ideológica sobre a experiência que se torna gesto invisível sobre o palco do poema. Vê-se em 
certas ocasiões algo de aristocrático, iniciático, excessivamente erudito que trai a espontaneidade tão reiterada por Willer. Piva sistematiza o viés rebelde de modo mais denso e notório em sua poesia, embora não deixe de apresentar o aspecto contraditório quando se trata da tensão entre letra e vida.

Willer, mesmo quando poeta, é irremediavelmente ensaísta. É sob essa ótica que ressalta inúmeras vezes o caráter transgressivo que considera indissociável da escrita, o que exprime aquela simpatia pela subversão e pela marginalidade ostentada tanto por Piva quanto pelo poeta de Estranhas Experiências.

poesia é velocidade

do disparo do revólver verdadeiro, da janela, no automóvel que ia passando por aquele alvo escolhido ao acaso, poesia é som,

o áspero ruído do gume de diamante sendo testado por dois especialistas em arrombamento na vitrina daquela loja de armas a $80 \mathrm{~m}$. de distância de uma delegacia (eu esperava no carro) (se houvesse cedido, levávamos tudo)

(“A palavra”, Estranhas experiências, 2004)

Neste mesmo “A palavra”, publicado no referido livro, a poesia é reconhecida como:

o conhecimento animal um núcleo raivoso anterior à Queda

- Gnose"

(...).

(idem). 
Exprime-se dessa forma uma concepção mística que tem no poético uma forma diferenciada e privilegiada de conhecimento. E é sob tal ponto de vista que o sujeito lírico afirma:

\author{
não quero falar, quero ser dito \\ sejamos densamente humanos \\ como a chuva \\ no ar saturado de excesso \\ (ibidem)
}

Percebemos que a opção pela visceralidade: "sejamos densamente humanos" pode ser uma forma de buscar a reintegração com o universo, pois o "eu" identifica o estado densamente humano que procura em um elemento da natureza: quer ser "como a chuva".

NOTAS CONCLUSIVAS

No posfácio ao terceiro volume das obras completas de Piva, o crítico Davi Arrigucci Jr. reconhece os poemas do autor como "Resíduo do tempo forte da inspiração" (2008, p.200). Ressalta, portanto, que como consequência disso "o poema corre o risco do informe ao preferir a autenticidade da expressão de uma experiência emocional intensa ao trabalho de arte." (idem). O crítico identifica também algo de estrutural no texto piviano ao apontar que "Embora episódico, o discurso toma a forma de um magma ou fluxo verbal contínuo, derivado da fala, para o qual um ritmo de repetições e associações se torna fundamental, combinando os materiais mais diversos em liga estreita e explosiva" (ibidem). 
Também podemos observar em Claudio Willer os mesmos riscos do "informe", a mesma preferência por uma "experiência emocional intensa" ao "trabalho de arte". Não há, no entanto, uma adesão ingênua ao delírio do verbo. Parece haver muito mais uma preocupação teórica. Engendra-se antes um tipo de sistema, um programa, uma filosofia da composição que deseja propor, para os fins do processo de escrita, a problemática em torno do sujeito em suas possibilidades existenciais.

Dentre as leituras que fazem parte de seus repertórios, podemos vislumbrar onde buscam o mito fundador de suas concepções artísticas. Assim como Antonin Artaud, desejam a efetividade da criação no sentido de "mudar a vida". Também em Ginsberg, Corso, Kerouac, percebemos tal ideia. Willer e Piva encaram como elemento inextrincável de seus escritos um desejo daquela "Libertação Psicológica e Total", da mesma forma que André Breton, veem na atividade poética "a mais fascinante Orgia ao alcance do Homem", como denuncia o dito de Piva no anteriormente citado "Postfácio" de seu livro Piazzas.

Willer expressa uma visão em tudo análoga à de Piva:

A poesia, tal como a concebo, é fruto de uma atividade mental mais ampla e profunda do que aquela pertinente à consciência que se desenvolveu dentro da nossa tradição cultural, pois visa exatamente ao alargamento e expansão dessa mesma consciência. A poesia, essencialmente vinculada à atividade do inconsciente, do inconsciente que desconhece os princípios da negação, da não identidade e da não simultaneidade que, exatamente, residem na base do pensar lógicoconceitual; do Inconsciente que possui uma dialética, uma dinâmica, em suma um pensar autônomos; a poesia concebida nesses termos , só pode apontar para áreas e fenômenos mais profundos e situados para além daqueles sob o alcance da limitada consciência ocidental, racionalista, cartesiana, cercada por uma estrutura social, ou seja, por uma 'realidade' repressora e compulsiva (WILLER, 1964, p.39) .

Definem-se, desse modo, categorias que estarão presentes em toda a obra do autor desde seu primeiro livro até as publicações mais recentes, incluindo seus ensaios: uma 
poesia "essencialmente vinculada à atividade do inconsciente", que aponta para fenômenos de superação da mentalidade ocidental sobre a qual se funda uma "realidade repressora e convulsiva". Esse viés, ao mesmo tempo em que prescinde do caráter puramente artístico, no sentido do "trabalho" de arte (ao ver sua atividade como plataforma rebelde), destaca a estrutura, a dinâmica, a lógica própria do inconsciente.

O que vemos é que Willer e Piva, de fato, reconhecem em certos elementos fixados pelo racionalismo o pilar de uma estrutura social, constitutiva de uma "realidade" pela qual têm aversão, por isso enfatizam sua atração pela marginalidade, e ratificam um misticismo do fazer literário. Primam pelo caráter não racional da existência, e, consequentemente, da escrita. Nesse jogo, muitas vezes acontece (o que se revela de modo mais evidente em Willer cuja ensaística e poesia não raro confluem) um excesso de racionalização ou de intelectualismo, fator que trai a visão tão reiterada em suas obras e também pelas suas declarações.

O poeta-bruxo é capaz de conjurar somente quando seu enunciado funciona. Essa questão pertence inevitavelmente à poesia enquanto formulação artística e simbólica. É na medida em que o poeta cria um mundo autônomo que pode apontar para outra ordem das coisas, dá-la à realidade negada, como utopia presente e brecha de uma existência mais livre.

No texto "A inspiração", de $O$ Arco e a Lira (1982), Octavio Paz parece resolver em termos o problema ao mostrar que tanto o poeta adepto da espontaneidade como o poeta cerebral que racionaliza e planeja todo seu processo, são surpreendidos por uma “outra voz". Aquele, da escrita aberta ao acaso e ao fluxo desordenado e ininterrupto do pensamento, vê que há uma estrutura, uma coerência de ideias, um jogo de repetições; já o poeta racional pode ter seu poema tomado de assalto por um termo, uma palavra, 
uma rima que, involuntariamente resolve a obra incapaz de continuar a ser construída pela via da razão.

Professar uma ou outra instância da criatividade seria entregar-se a uma falsa questão. Interessa o porquê das invectivas de Willer e Piva contra a dita poesia escrita a frio, interessa-nos, sobretudo observar como nesses escritores a poesia pode se dar como "linguagem em estado de crise". A poesia é um discurso livre dado às propriedades mais inusitadas e anárquicas da imaginação e da nossa vida interior entendida de um modo mais amplo.

Consideramos que a esfera artística deve existir livre do peso de todo e qualquer aparato ideológico, até mesmo daquele que pertence à sua própria natureza autônoma. Piva e Willer contribuem para uma espécie de revitalização da poesia, sobretudo nos momentos em que de fato cristalizam a experiência em arte, no sentido de que convidam o leitor ao prazer do texto - dessa forma, os textos willerianos e pivianos se desdobram, atraem, enfim, para a prática da poesia: fazem o leitor senti-los como se estivessem sendo feitos no momento mesmo da leitura - o leitor é participante da vivência criadora do poema à medida que este se transpõe de modo visceral para a obra.

É assim que Willer em um poema como "Viagens (MAIS UMA VEZ)", de Jardins da provocação, efetiva a união entre corpo e signo, encarnando-a no aspecto sensorial da escrita:

mergulho no amor

com a cega convicção dos suicidas

penetro passo a passo

nesta região misteriosa 


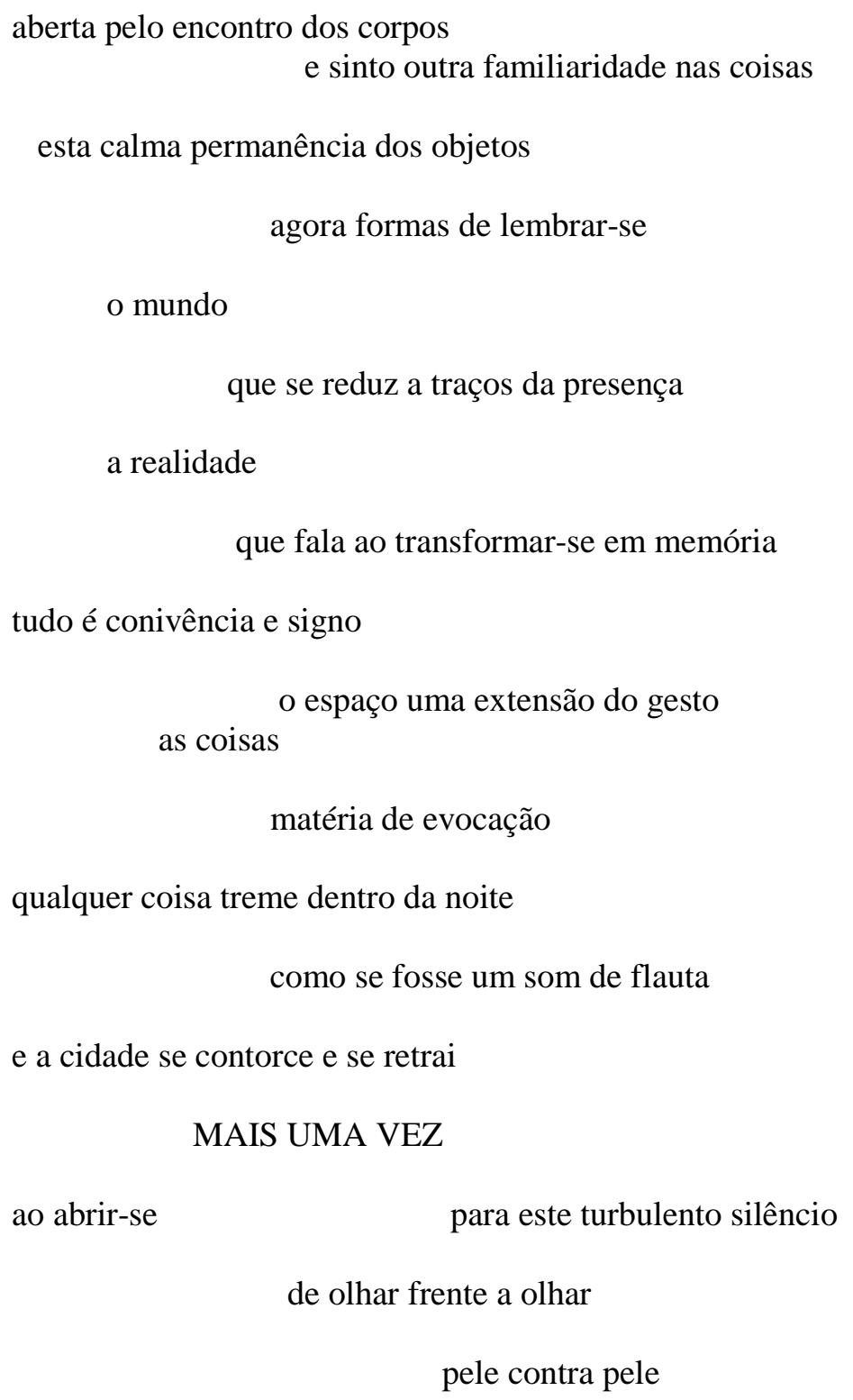

O poema impõe-se pelo ritmo pausado, uma pulsação que se dilata e se retrai reproduzindo a hesitação do encontro amoroso, capaz, como mostra o próprio texto, de transfigurar a visão que o sujeito tem do mundo. Assim, o espaçamento dos versos na página mimetiza a aproximação gradativa. Há uma atmosfera silenciosa que se vê 
ameaçada pelas aliterações em $\boldsymbol{T} \boldsymbol{R}$, tais como aparecem no sétimo, oitavo, decimo segundo e décimo quarto versos. Notemos que no décimo nono verso o recurso em questão aparece duas vezes: "qualquer coisa TReme denTRo da noite" figurando o impacto do encontro como forma de definir, pela perturbação que promove no sujeito lírico, uma ruptura do vácuo citadino. O amor faz com que a cidade, a ameaçadora urbe se contorça e se retraia ante o "turbulento silêncio" do contato entre os amantes a reestabelecer a possibilidade de aventura da vida frente à reificação. $\mathrm{O}$ tremor, a turbulência que o poema reproduz refere-se tanto à ameaça representada por tal vivência (capaz de redefinir as coisas que se cobrem de outros significados) quanto ao medo que dela faz parte.

Piva, mesmo em seus momentos aparentemente mais delirantes sempre se mostrou consciente da forma. Tal afirmação pode ser atestada pelo trabalho com o verso livre em Paranoia, também pela condensação (ainda anterior a Ciclones) de livros como vinte poemas com brócoli (1981) a qual podemos ver no poema abaixo:

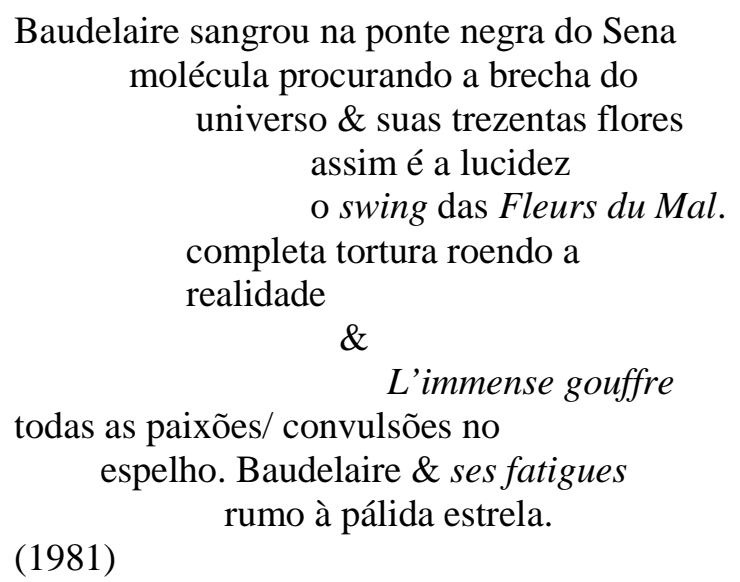

Assim, o poema se mostra econômico. A plasticidade das imagens, claras, límpidas: o trânsito imagético do Baudelaire que sangra sobre a ponte do Sena à figura do poeta seguindo rumo "à pálida estrela", demonstram consciência artística e apuro formal. 
Depreendemos dessas questões que tanto Piva como Willer, à revelia de seus projetos ou concepções artísticas, demonstram que o melhor da arte poética de ambos se revela é mesmo nos poemas. E que suas posições políticas continuam a depender da esfera autônoma da arte - a ruptura que possam, porventura, irradiar deve-se, sobretudo ao modo como trabalham com a prosódia, sistematizam suas leituras e executam sua cisão como escritores. No entanto, colocam uma questão primordial em nosso tempo: até que ponto a poesia é capaz de deslizar fugindo das garras de todo tipo de dominação que se impõe à existência humana por meio da sociedade burguesa sancionada pela racionalidade voltada para os fins? Michael Hamburger, em A verdade da Poesia (2007), ao tratar de questões semelhantes conclui que:

Aquilo que ameaça a sobrevivência da poesia é o que ameaça a sobrevivência da própria civilização, de qualquer tipo de verdade, de qualquer tipo de atividade significativa - nossas especializações fragmentadoras e fragmentadas, burocráticas, técnicas, econômicas e políticas. Enquanto a ameaça estiver contida, é provável que se escreva poesia de um tipo ou de outro, pois que ela é tão resistente e adaptável quanto seu criador, o homo faber, e suas verdades continuarão a ser a um só tempo relativas quanto às condições de sua sobrevivência e absolutas em sua necessidade de transcendê-las. (p.443)

Tal parece ser para nós, a trincheira em que os poetas Roberto Piva e Claudio Willer atuam. A tensão que criam, seja pelos seus poemas, pela presença na vida cultural brasileira, seja pela poesia e ensaística, no caso de Willer, atesta a importância de suas obras. E, mais que isso, o fato de que há vários poetas mais recentes influenciados por Piva e Willer, podemos citar como exemplo Sergio Cohn, Floriano Martins, Rodrigo Petrônio e tantos outros cuja vocação criativa teve, de alguma forma contato com a chama entusiasta de nossos poetas. 
Já sobre o problema da separação entre a arte e a vida, podemos dizer com o Peter Bürger de "O declínio da Era Moderna" que: "se a exigência vanguardista de abolir essa separação for factível, isso será o fim da arte. Caso se abandone essa exigência, ou seja, se a separação entre arte e vida for aceita como uma questão de fato, também será o fim da arte" (1988, p. 95). 
ANEXO: (Manifestos)

\section{O Minotauro dos minutos}

Os pontos cardeais dos nossos elementos são: a traição, a não compreensão da utilidade da vidraças, a violência montanha-russa do Totem, o rompimento com os labirintos e nervuras do penico estreito da Lógica, contra o vosso êxtase açucarado, vós como os cães sentis necessidade do infinito, nós o curto-circuito, a escuridão e o choque somos contra a mensagem lírica do Mimo, contra as lantejoulas pelos caracóis, contra a vagina pelo ânus, contra os espectros pelos fantasmas, contra as escadas pelas ferrovias, contra Eliot pelo Marquês de Sade, contra a polenta pelo ragu, nós estamos perfeitamente esquizofrênicos, paranoicamente cientes de que devemos nos afastar da Bandeira das Treze Listas cujos representantes são as bordadeiras de poesia que estão espalhadas por toda a cidade.

\section{Bules, Bílis e Bolas}

Nós convidamos todos a se entregarem à dissolução e ao desregramento. A Vida não pode sucumbir no torniquete da Consciência. A Vida explode sempre no mais além. Abaixo as Faculdades e que triunfem os maconheiros. É preciso não ter medo de deixar irromper a nossa Alma Fecal. Metodistas, psicólogos, advogados, engenheiros, estudantes, patrões, operários, químicos, cientistas, contra vós deve estar o espírito da juventude. Abaixo a Segurança Pública, quem precisa disso? Somos deliciosamente desorganizados e usualmente nos associamos com a Liberdade. 


\section{A máquina de matar o tempo}

Aqui nós investimos contra a alma imortal dos gabinetes. Procuramos amigos que não sejam sérios: os macumbeiros, os loucos confidentes, imperadores desterrados, freiras surdas, cafajestes com hemorroidas e todos que detestam os sonhos incolores da poesia das Arcadas. Nós sabemos muito bem que a ternura de lacinhos é um luxo protozoário. Sede violentos como uma gastrite. Abaixo as borboletas douradas. Olhai o cintilante conteúdo das latrinas.

\section{A catedral da desordem}

A nossa batalha foi iniciada por Nero e se inspira nas palavras moribundas: "Como são lindos os olhos deste idiota". Só a desordem nos une. Ceticamente, Barbaramente, Sexualmente. A nossa Catedral está impregnada do grande espetáculo do Desastre. Nós nos manifestamos contra a aurora pelo crepúsculo, contra a lambreta pela motocicleta, contra o licor pela maconha, contra o tênis pelo box, contra a rádio-patrulha pela Dama das Camélias, contra Valéry por D. H. Lawrence, contra as cegonhas pelos gambás, contra o futuro pelo presente, contra o poço pela fossa, contra Eliot pelo Marquês de Sade, contra a bomba de gás dos funcionários públicos pelos chicletes do eunucos e suas concubinas, contra Hegel por Antonin Artuad, contra o violão pela bateria, contra as responsabilidades pelas sensações, contra as trajetórias nos negócios pelas faces pálidas e visões noturnas, contra Mondrian por Di Chirico, contra a mecânica pelo Sonho, contra as libélulas pelos caranguejos, contra os ovos cartesianos pelo óleo de Rícino, contra o filho natural pelo bastardo, contra o governo por uma convenção de cozinheiros, contra os arcanjos pelos querubins homossexuais, contra a invasão de borboletas pelas invasão de gafanhotos, contra a mente pelo corpo, contra o Jardim 
Europa pela Praça da República, contra o céu pela terra, contra Virgílio por Catulo, contra a lógica pela magia, contra as magnólias pelos girassóis, contra o cordeiro pelo lobo, contra o regulamento pela Compulsão, contra os postes pelos luminosos, contra Cristo por Barrabás, contra os professores pelos pajés, contra o meio dia pela meianoite, contra a religião pelo sexo, contra Tchaikowsky por Carl Orff, contra tudo por Lautréamont.

Os que viram a carcaça

Roberto Piva S. P. Março de1962.

\section{MANIFESTO DA SELVA MAIS PRÓXIMA}

Para Henri Michaux

"abolição de toda a convicção que dure mais que um estado de espírito" Álvaro de Campos

in memoriam

Os produtos químicos, a indústria farmacêutica \& os miasmas roerão teus ossos até a medula / cadáver rico em vitaminas / rodopios no rio da indústria / burocratas ideológicos morrendo de rir / marxistas que depois que arrancaram a próstata tomaram o poder / vastos desertos no Cérebro / políticos estatísticas câncer no rosto vazio das avenidas da Noite / Mulheres agarrando garotos selvagens para enquadrá-los no Bom Caminho / assobios \& fome do verdadeiro caralho fumegante / Robert Graves, BrillatSavarin \& o refrão dos meus desejos / Feiticeiro Ecológica no Liquidificador Minotauro / hortaliças incineradas por mercúrio / botinadas da KGB \& canções lancinantes / Tempo no osso / Televisão / Centauro na rota da Revolta / Estrelas penduradas na fuligem / Catecismo da Perseverança Industrial / Os governos existem pra te deixar com 
esse ar de cachorro batido / Os governos existem pra preparar a sopa do General Esfinge / Os governos existem pra você pensar em política \& esquecer o Tesão / Batuque Nuclear Anjo-Fornalha / poesia urbana-industrial em novo ritmo / Cidade esgotada na feiura pré-Colapso / recriar novas tribos / renunciar aos trilhos / Novos mapas da realidade / roteiro erótico roteiro poético/ Horácio \& Lester Young / Tribos de garotos nas selvas / tambores chamando pra Orgia / fogueiras \& plantas afrodisíacas / Abandonar as cidades / rumo às praias salpicadas de esqueletos de Monstros / rumo aos horizonte bêbados como anjos fora da rota / Terra minha irmã / entraremos na chuva que faz inclinar à nossa passagem os Guaiambés / Delinquência sagrada dos que vivem situações-limites / É do Caos da Anarquia social que nasce a luz enlouquecedora da Poesia / Criar novas religiões, novas formas físicas, novos anti-sistemas políticos, novas formas de vida / Ir à deriva no rio da Existência.

\section{ROBERTO PIVA}

Hora Cósmica da Águia

SP outubro de 1984 


\section{REFERÊNCIAS BIBLIOGRÁFICAS:}

ADORNO, TW. Notas de literatura I. Trad. Jorge de Almeida. São Paulo: Duas Cidades/Editora 34, 2003.

ALLEN, Donald Merriam. Org. The new American poetry, 19451960. University of California Press, 1999.

ANDRADE, Fábio de Sousa. "Retórica da vertigem". Rodapé Crítica de literatura brasileira contemporânea, $\mathrm{n}^{\circ} 1$. São Paulo: Nankin, 2001.

ANDRADE, Mário. Poesias completas. 3. Ed. São Paulo: Martins; Brasília, INL, 1972.

ANDRADE, Oswald. A Utopia Antropofágica. São Paulo; Globo,

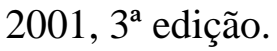

ARRIGUCCI Jr; Davi. O Escorpião Encalacrado. São Paulo: Companhia das Letras, 1973.

__. "O mundo delirante (a poesia de Roberto Piva)". In: Estranhos sinais de Saturno. Obras reunidas. Vol.3. (Org.) Alcir Pécora. São Paulo: Globo, 2008.

ARTAUD, Antonin. Escritos de Antonin Artaud. Trad. Claudio Willer. Porto Alegre: L\&PM, 1966. 
_. Linguagem e Vida. Organização J- Guinsburg, Sílvia Fernandes

Telesi e Antônio Mercado Neto. São Paulo: Perspectiva, 1970.

O Pesa-Nervos. Trad. Joaquim Afonso. Lisboa: Hiena Editora, 1991.

BATAILLE, Georges. A Literatura e o Mal. Trad. Suely Bastos. Porto Alegre: L\&PM, 1989.

BAUDELAIRE, Charles. Poesia e Prosa. Vários tradutores. Org. Ivo Barroso. Rio de Janeiro: Nova Aguilar, 2002.

BENJAMIN, Walter. "O surrealismo. O último instantâneo da inteligência europeia”. In: BENJAMIN, Walter. Magia e Técnica, Arte e Política. Ensaios sobre literatura e história da cultura. Trad. Sérgio Paulo Rouanet. 7ed. São Paulo: Brasiliense, 1994. (Obras escolhidas, v.1)

BERLIN, Isaiah. "A Apoteose da Vontade Romântica", in: Estudos sobre a humanidade. Uma antologia de ensaios. São Paulo: Cia das Letras, 2002.

BOSI, Alfredo. O Ser e o Tempo da Poesia. São Paulo: Companhia das Letras, 2000.

BRAUNE. Fernando. O surrealismo e a estética fotográfica. Rio de Janeiro: 7 Letras, 2000.

BRETON, André. Manifestos do Surrealismo. Trad. Sérgio Pachá. Rio de Janeiro: Nau Editora, 2001.

_.. Nadja. Trad. Ivo Barroso. São Paulo: Cosac \& Naify, 2007. 
BÜRGER, Peter. Teoria da Vanguarda. Trad. José Pedro Antunes. São Paulo: Cosac \& Naify, 2008.

_. “O declínio da era moderna". In Revista Novos Estudos CEBRAP, n. 20, março de 1988

_. "O significado da vanguarda para a estética contemporânea": resposta a Jürger Habermas. In: Arte em Revista. Ano 5, nº 7, Agosto de 1983.

CHAVES, Reginaldo Sousa. FLANAR PELA CIDADE-SUCATA COMPONDO UMA ESTÉTICA DA EXISTÊNCIA: Roberto Piva \& seu Devir Literário Experimental (1961-1979). Dissertação de mestrado. Orientador: Edwar de Alencar Castelo Branco. Universidade Federal do Piauí, 2010, (p.31).

CÁMARA, Mario. "Sexualidad y ciudad en la poesía de Roberto Piva”. In: anclajes XIV, dezembro de 2010.

CAMPOS, Augusto; CAMPOS, Haroldo; Pignatari, Décio. Teoria da Poesia Concreta. Duas Cidades: 1975.

COELHO, Nelly Novaes. "Eunice Arruda". In: Dicionário crítico das escritoras brasileiras, 2002.

FOSTER, Hal. The return of the real: the Avant-garde at the End of the Century. Cambridge: MIT Press, 1996.

FRANCESCHI, Antonio Fernando De. "Altero todo um ser, pois que me movo". In: Azougue 10 anos (Org. Sergio Cohn). Rio de Janeiro: Editora Azougue: 2004. 
_. "Notas de um percurso". In: MASSI, Augusto. Org. Artes e Ofícios da Poesia. Porto Alegre e São Paulo: Artes e Ofícios Editora e Secretaria Municipal de Cultura, 1991.

FRIEDRICH, Hugo. Estrutura da lírica moderna. Trad. Marise M. Curioni. São Paulo, Duas Cidades, 1978.

GENDRON, Jacqueline Chénieux. O surrealismo. Trad. Mário Laranjeira. São Paulo: Martins Fontes, 1992.

GINSBERG, Allen. Uivo, Kaddish e Outros poemas. Tradução, prefácio e notas de Claudio Willer. Porto Alegre: LP\&M, 1999.

_. Uivo e outros Poemas. Tradução, prefácio e notas de Claudio Willer. Porto Alegre: L\&PM, 2005.

_. Howl, Original draft facsimile, and variant versions, fully annotated by author. New York , HarperCollins Publishers, 2006.

GUINSBURG, Jacó (org.). O Romantismo. São Paulo: Perspectiva, 1978.

HABERMAS, Jürger. "modernidade versus Pós-modernidade”. In: Arte em Revista. Ano 5, nº 7, Agosto de 1983.

HAMBURGER, Michael. A Verdade da Poesia. Trad. Alípio Correia de Franca Neto. São Paulo: Cosac \& Naify, 2007.

HARO, Rodrigo de. "A implacável poesia". In: Azougue 10 anos (Org. Sergio Cohn). Rio de Janeiro: Editora Azougue: 2004. 
HOLLANDA, Heloisa Buarque. Impressões de Viagem. Rio de Janeiro: Editora Rocco, 1992.

HUYSSEN, Andréas. "A busca da tradição: vanguarda e pósmodernismo nos anos 70. In: Arte em Revista. São Paulo: CEAC, Ano 5, nº 7, Agosto de 1983.

KAFKA, Franz. O Processo. Trad. Modesto Carone. Rio de Janeiro: O Globo; São Paulo: Folha de S. Paulo, 2003.

KAWANO, Marta. Gérard de Nerval: A Escrita em Trânsito. São Paulo: Ateliê Editorial, 2009.

LAUTRÉAMONT, Conde de. Os cantos de Maldoror, poesias, cartas. Obra Completa. Tradução, prefácio e notas de Cláudio Willer. São Paulo: Iluminuras, 2005.

LEITE, Danilo Monteiro Ferreira. Teatralidade da palavra poética em Paranoia de Roberto Piva. Dissertação de mestrado. Orientadora: Maria Augusta Bernardes Fonseca Weber Abramo. Universidade de São Paulo. 2010.

LIMA, Sérgio. A Aventura Surrealista, Editora da UNICAMP; São Paulo: UNESP; Rio de Janeiro : Vozes, 1995.

LORCA, Federico Garcia. Obra poética completa. Trad. William Angel de Mello: Martins Fontes, 2002.

LÖWY, Michel; SAYRE, Robert. Trad. Guilherme João de Freitas Teixeira. Petópolis, RJ: Vozes, 1995. 
MASSI, Augusto. Org. Artes e Ofícios da Poesia. Porto Alegre e São Paulo: Artes e Ofícios Editora e Secretaria Municipal de Cultura, 1991.

MCCLURE, Michael. A nova visão de Blake aos Beats. Trad. Daniel Bueno, Luiza Leite Sérgio Cohn. São Paulo: Azougue editorial, 2005.

MOISÉS, Carlos Felipe. "Vida experimental". In: O Desconcerto do Mundo: do Renascimento ao Surrealismo. São Paulo: Escrituras Editora, 2001.

_., FARIA, Álvaro Alves. (Org.) Antologia poética da geração de 60. São Paulo: Nankin Editorial, 2000.

MORAES. Eliane Robert. “A cintilação da noite”. In: Mala na mão e asas pretas. Obras reunidas Vol. 2. (Org) Alcir Pécora. São Paulo: Globo, 2006.

NADEAU, Maurice. História do Surrealismo. São Paulo: Perspectiva, 1997.

NERUDA, Pablo. Antologia Poética. Rio de Janeiro: José Olympio Editora, 1978.

NIETZSCHE, Friedrich. Assim falou Zaratustra. São Paulo: Círculo do Livro.

NOVALIS. Pólen. Trad. Rubens Rodrigues Torres Filho: $2^{\circ}$ edição, São Paulo: Iluminuras, 2001.

NOYA, Thiago de Almeida. Roberto Piva e a "periferia rebelde". Dissertação de mestrado. Orientador: Ítalo Moriconi. Universidade do Estado do Rio de Janeiro, 2004. 
PAES, Jose Paulo. "Surrealismo no Brasil", in: Gregos e Baianos. Editora Brasiliense, 1985.

PAZ, Octavio. A outra Voz, Trad. Wladir Dupont, São Paulo; Eitora Siciliano, 1990.

_. O Arco e a Lira. Trad. Olga Savary. Rio de Janeiro: Nova Fronteira, 1982.

_.. Os filhos do barro. Trad. Olga Savary. Rio de Janeiro: Nova Fronteira: 1984.

_. Signos em rotação. Trad. Sebastião Uchoa Leite. São Paulo: Perspectiva, 1972.

PÉCORA, Alcir. "Nota do organizador". In: Um estrangeiro na Legião. Obras reunidas. Vol. 1 (Org) Alcir Pécora. São Paulo: Globo, 2005.

PESSOA, Fernando. Obra Poética. Rio de Janeiro: Nova Aguilar, 1986.

PIVA, Roberto. Ciclones. São Paulo: Nankin, 1997.

_..Um estrangeiro na Legião. Obras reunidas. Vol. 1 (Org.) Alcir Pécora. São Paulo: Globo, 2005.

_.. Mala na mão e asas pretas. Obras reunidas Vol. 2. (Org.) Alcir Pécora. São Paulo: Globo, 2006.

_. Estranhos sinais de Saturno. Obras reunidas. Vol.3. (Org.) Alcir Pécora. São Paulo: Globo, 2008. 
PONGE, Robert (org). Surrealismo e Novo Mundo. Porto Alegre: Ed.

\section{UFRGS}

RAYMOND, Marcel. De Baudelaire ao Surrealismo. Trad. Fúlvia M. L. Moretto e Guacira Marcondes Machado. São Paulo: EDUSP, 1997.

RIMBAUD, Arthur. Iluminuras, gravuras coloridas. Trad. Rodrigo Garcia Lopes e Maurício Arruda Mendonça. São Paulo: Iluminuras.

ROSZAK, Theodore. Para uma Contracultura. Lisboa: Publicações Dom Quixote.

SPITZER, Leo. Lingüistica e Historia Literaria. Madri: Editorial Gredos.

SCHWARZ, Roberto. “Cultura e política, 1964-1969”. In: O pai de família e outros ensaios. Rio de Janeiro: Paz e Terra, 1978.

SONTAG, Susan. Sob o Signo de Saturno. Trad. Ana Maria Capovilla e Albino Poli Jr. Porto Alegre: L\&PM, 1986.

TALMON, J.L, Romantismo e Revolta. Trad. Tomé Santos Júnior. Lisboa: Verbo Editorial.

TREVISAN, João Silvério. "A arte de transgredir", in: Pedaço de Mim. São Paulo: Editora Contra-luz.

TZARA, Tristan. Sete Manifestos dada. Trad. José Miranda Justo. Lisboa: Hiena Editora, 1987.

VANEIGEM, Raoul. The Revolution of everyday Life. Translated by Donald Nicholson-Smith. Rebel Press: London, 2001. 
WILLER, Claudio. Anotações para um apocalipse. São Paulo: Massao Ohno, 1964.

_. "A cidade, os poetas, a poesia". In: Antologia poética da geração de 60. São Paulo: Nankin Editorial, 2000.

_. Dias Circulares. São Paulo, Massao Ohno, 1976.

_. Estranhas experiências e outros poemas. Rio de Janeiro: Editora Lamparina, 2004.

_. (vários autores) Alma Beat, ensaios sobre a Geração Beat. Porto Alegre: L\&PM, 1984.

_. Jardins da Provocação. São Paulo: Massao Ohno e Rosita Kempf Editora1981.

__. "Uma introdução à leitura de Roberto Piva". In: Um estrangeiro na Legião. Obras reunidas. Vol. 1 (Org) Alcir Pécora. São Paulo: Globo, 2005.

_. Geração Beat. Porto Alegre: L\&PM, 2009.

WILSON, Edmund, O Castelo de Axel, tradução de José Paulo Paes, São Paulo, Companhia das Letras, 2004. 
Sites:

"Carlos Felipe Moisés: Entrevistas": http://www.revista.agulha.nom.br/cfm4.html.

"Claudio Willer: meditações de emergência (entrevista)"

http://www.revista.agulha.nom.br/ag34willer.htm.

“Um encontro com Claudio Willer" Entrevista, por Floriano Martins:

http://www.ucm.es/info/especulo/numero13/c_w_ent.html.

Entrevista com Álvaro Alves de Faria: http://www.alvaroalvesdefaria.com/\#/panoramaeditorial/4529455500.

"Encarnações da poesia": http://www.revista.agulha.nom.br/cw1.html.

“Há método em sua loucura”, Maria Rita Khel. Estadão 10 de julho de 2010:

http://www.estadao.com.br/noticias/impresso,ha-metodo-em-sua-loucura,579155,0.htm.

“Ebulições pivianas”. Entrevista com Roberto Piva, por Paula Dume e Renata D’Ellia:

http://www.cronopios.com.br/site/artigos.asp?id=2739.

“Estranhas experiências: Claudio Willer e a Geração Beat". Ensaio de Lucila Nogueira: http://www.revista.agulha.nom.br/ag43willer.htm.

“A União Livre”. Poema de André Breton. Trad. Priscila Manhães e Carlos Eduardo

Ortolan: http://www.revistazunai.com/traducoes/andre_breton.htm.

“Entrevista com Claudio Willer”, por Claudio Daniel:

http://www.elsonfroes.com.br/cwillerent.htm.

"Entrevista com Roberto Piva". Site Telescópio:

http://telescopio.tipinhus.com/entrevista.htm. 